\title{
圆形胃潰瘍形成, 實驗的研焭
}

日本赤小学社兵庫支部姫路病院外科及病理科

翳學士小

目

序㒛

第 1 章 余力゙顀驗方法

(1) 實驗動物

(2) 手術方法

(3) 標本檢查法

(4) 贯驗訑錄

第 1 項術後 1 日

第 2 項 術後1週開 $コ$ 2週間二全ル實驗侧

第3 項 術後3週間 $コ$ 5週間二至ル實驗例

第 4 項 術後 10 週間以後, 實驗例

（5）其驗成績/總括及考按:

第 2 章大網膜切除卜胃溃陽發生卜，關係

第 1 項文献

第 2 項 實驗記錄

第 3 項 實驗戍績)總括及考按
俣武

大

第 3 章 胃大湆二於テ幽門㡏ヨリ左胃網動静脈 ニ至ル總デ血管キ結紮或ハ結紮切断 セル筫驗.

第 4 笪 大網膜右牛及胃十二指腸動静脈分枝， 呦門ニ入ル部分キ血管卜共二組織キ全 切除をル筫驗

第 5 章 胃十二指腸動静脈結紮

第 6 章 贯十二.指腸動脈結紮

第 7 章 胃十二指腸静脈結奖

第 8 章 腸管ノ癒著二ヨル眮壁副血行新生ノ舅 潰場發生二及ボ入影響

第9章 本編/總括及考按

參考書目

附圆境明，附鯆

\section{序鿷}

胃潰啺ガ獨立，疾患トシテ認メラル、ニ至リシハ，西紀1820年 Cruveilhier 氏 ，提唱二由ル，爾來，本疾患二關スル䂰究八，次第二旺盛トナリ，幾多，學者 相繼イデ, 各方面ョリ七ル研究業績 發表シタリ。持二, 實驗的二, 動物ノ胃 二潰場 ヨ形成セシメテ，之レガ成因 ヨ探索七ントスル者續出シ，各自己，實驗 ヨ基礎トシテ，甲論乙駁シ，今日二至レリ。而カモ，本获患八本態二就テ，

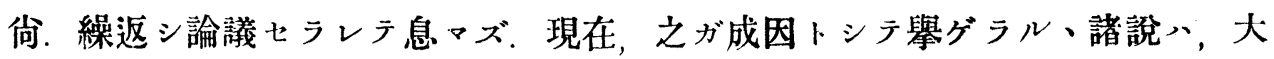
約次 $12=[$ 區別スルコトア得.

（1）血行障礙說（動脈說，静脈說)。（）种經障礙說

（3）胃液過酸症說 (+) 外傷說 (5) 炎症說

（6）傳染說 （7）肝障䂠說。（8）胃毒說. 
(9) あんちぺ゚しん減弱說.

(10)とりぷしん逆流說.

(11) 副腎障礙說

（12）一定八體質，疾病(贸血，萎黄病）若クハ, 火傷二關係アリトナス說.

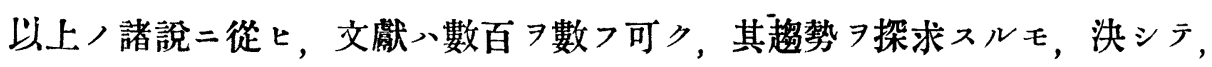

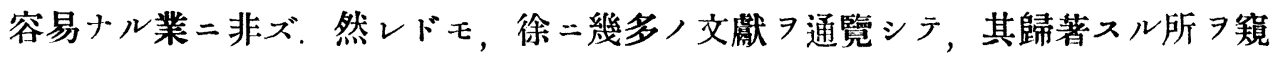

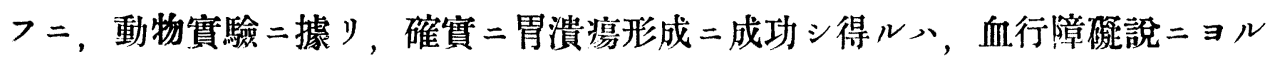
諸實驗ノミナリト云フモ，敢テ渦言二非ズ，其他ノ說ニヨル諸種實驗入，極メ テ稀二胃二潰歾 ヨ度外視シ得ザルモ，多シ。殊二，最近我國二於テ，後藤七郎氏（大正10年）

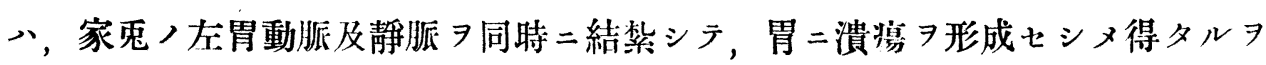
報告シ, 近森正基氏（大正12年）八，之习追試シテ，家鬼二於テハ左胃動脈，

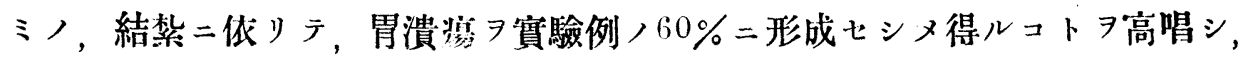

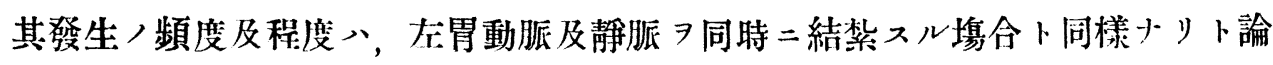
ゼリ。 又，本田郁也氏（大正13年）、犬 7 用七, 其胃動脈二石松子 7 泩入シテ,

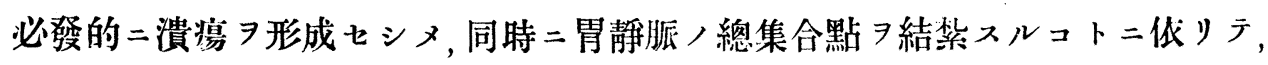
潰婸ハ慢性ノ經過 $\ni$ 取ルニ至ルト報告セリ。

從來, 諸家, 經驗ニョレバ, 動物, 胃二出入久ル血管, ミ, 結棌ニ因リテ 八，潰湯八形成入困雜ナリトセラレシガ，前記，後藤，近森八兩氏入，コノ方

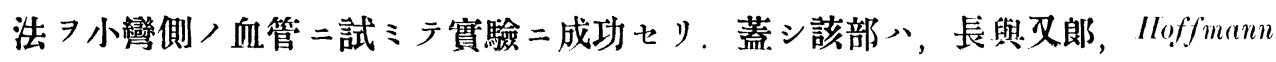
及 Nuther 等諸氏，研究二據レバ, 血管吻合，僅少ナル部位ニシテ，同特二亦人 類圓形潰湯ノ好發部位ナル 亦, 諸家夙二實驗二努メタリト雖 $モ$, 確實ナル成績, 擧ガリタリシコトフ聞カ

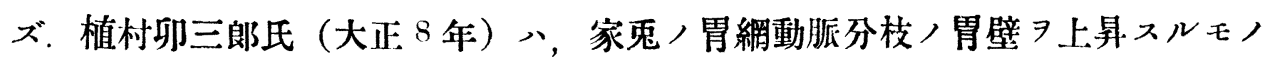
ヨバ，相伴フ靜脈卜共 $=2$ 個所，或、，數個所 $=$ 結紫シ，其中間 $=テ$ 血管 $\ni$ 切斷七ルモ，何等其部位。潰場，發生ナシト報告入，人米久之氏（昭和 2 年） 八, 日本病理學會席上二於テ, 十二指腸潰場研究，發表二際シ。胃十二指腸動

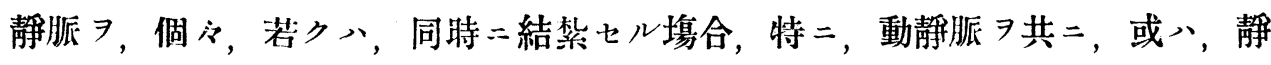

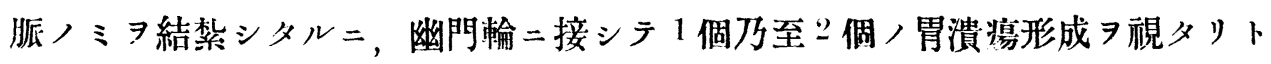

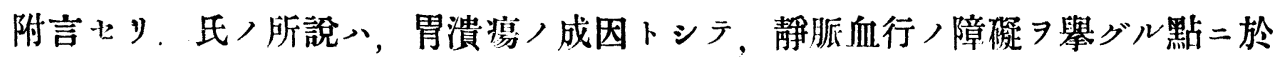




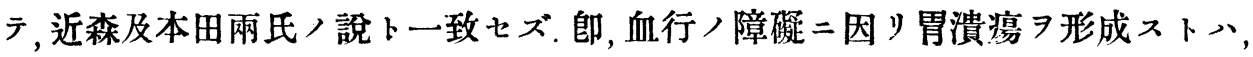
既二一般二認メラルル所ナルモ, 其動脈血行 ヨ主因トスルヤ, 静脈血行, 障礙 モ, 亦, 主因トナリ得ルャ二就テハ,上記諸家ノ間二モ未ダ見解ノ異ルモノアリ。

以上，余八，最近我國二於ル數氏，研究 $习$ 擧ら゙タルニ止メ，本疾患研究二 關スル業績ノ全者ヨ, 茲二縷述スルコトヨ避ケタルモ, 從來, 血行ノ障害二因 リ，動物八胃二潰場 形成セシヌ得タリト云フ諸家，實驗

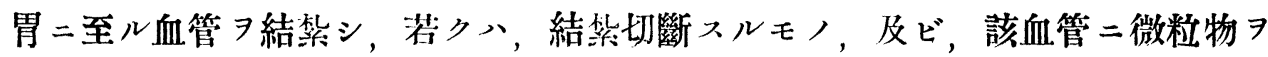
泩入スルモノトノ2樣二限ラル，從テ，其手術的操作二作フ周圍組織八反應的

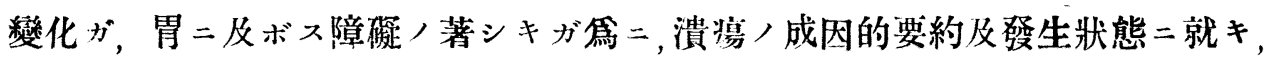
劃一的成績 $\ni$ 得難

余ハ, 先ッ゙, 如何ニシテ比較的簡單ナル操作要約二據りテ, 胃ノ一定部位二, 畧 同一型態 7 有スル潰湯 企圖セシガ, 幸二, 本編第1章二於テ述ルガ如キ實驗ニヨリ, 此目的 7 達成シ得タ

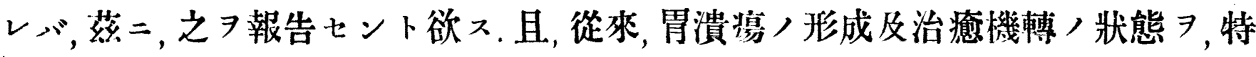
二系統的二, 肉眼的並二組織學的觀察 7 試ミタル學者無キヨ以テ, 之ガ檢索二努 メ，其得タル成績二立脚シテ，胃潰崲發生／原因ニ就テモ述ル所アラントス。

\section{第 1 章 余力實驗方法}

\section{（1）䔈 驗 動 物}

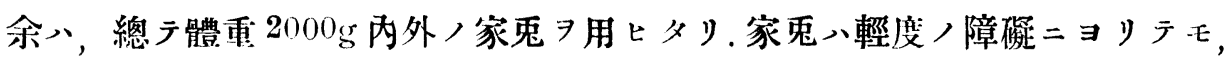
其胃二粘膜出血乃至糜爛习惹起シ易キガ故二，胃潰揚形成，實驗動物トシテン 不適當ナリト主張スル人々アリ（河村叶一氏，本田郁也氏等），反之，何等其 支障ナキヨ主張スルヒノモアリ（後藤七郎氏，近森正基氏，熊野御堂進氏等). 惟フ二, 粘膜出血乃至糜爛入, 極メテ短時日ノ中ニ治癒スルモノニシテ，胃潰

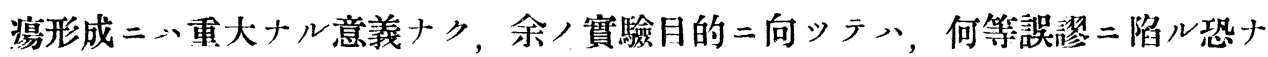
キモノナリ.

\section{（2）手 術 方 法}

術者及助手，手八，Firlbringer 氏法二從七消毒入，胃，手術操作习容易ナラシ ムル第二, 家鬼⼀書夜絕食セシヌ置キ，之背位二固定シ，其腹部ノ毛 7 可 及的短ク剪去シタル後， Grossich 氏沃度厂幾消毒法习施入。麻醉八總テ之ヨ用 
ヒズ，劍狀突起下白線二於 胃大彎壁二接シテ血管卜共二切除ス，左胃網動靜脈，中心部八，脾臟 $1 \mathrm{~cm}$ ，部二於テ，大網組織卜共二切斷三，右胃網動静脈八，其胃十二指腸動静 脈 $コ$ 去ル $1 \mathrm{~cm} /$ 部二於テ，大維組織ト共二切滋ス，少，胃十二指腸動靜脈小分 枝ノ幽門ニ入ル部分ヨモ，小ナル動脈癗針ニ2 條ノ糸 結紮切斷入。而シテ再ビ腹壁 72 層二縫合シテ手術 7 終ル。

\section{（３）管本檢查法}

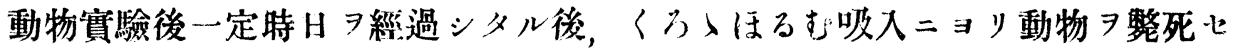
シメ，直二剖檢入，顯微鏡䌘本、，ちえういぢん包理二依ッテ切片 $ヨ$ 作リ，之 二主トシテ、へまときしりん，㤩をじん復染色，わんきいそん法わいげると 氏彈力繊維染色法 7 施シ，其他必要二應シ，適當，染色法 7 使用七リ。一部分

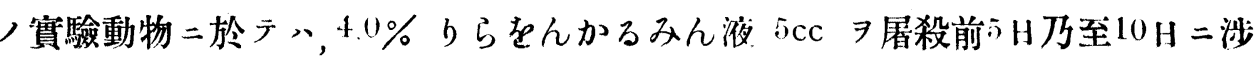
リ，毎日 1 回，具嗀靜脈ヨリ泩入シテ生體染色法 7 行へリ。

\section{（4）實 驗 部 錄}

上述ノ手術式二據リタル實驗家鬼入，手術淔後二於关ハ稍運動不活潑トナル モ，時日經過卜共二速二常態二復ス，但，此際泩月ス心゙キ八被驗動物ノ體重八

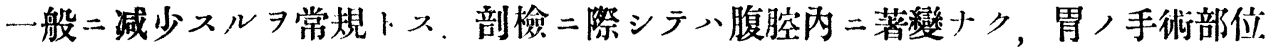
モ他臟器，若クハ，腹璧ト癒著スルコト無キヨ以テ, 特殊病變 7 伴ハザル限リ， 單二胃二於ル所見ノミラ記載ス。

\section{第 1 項 衙後 1 日コリ 5 日マデノ賽驗例}

贯騟家鬼第 1 號 體重 $1920 \mathrm{~g}$

昭和 3 年 4 月 17 日手術. 4 月 18 日管殺, 生存期間 1 日, 體重 $1790 \mathrm{gg}$.

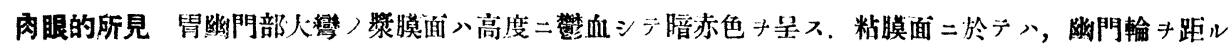

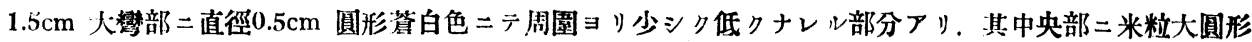
つ粘膜铁損アリテ淡紅色キ呈ス，其他，胃二著變ナシ。

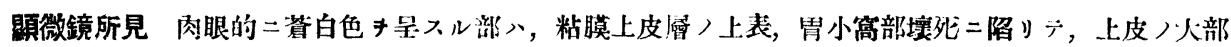

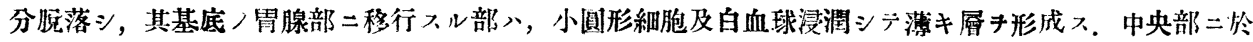

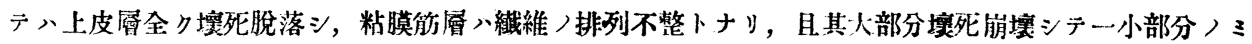

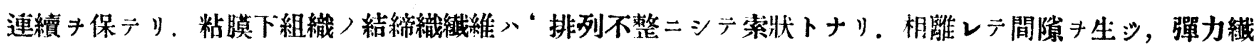

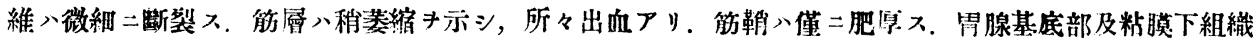
中／血管擴張シテ，强度 $=$ 允盈シ，其周圍二小圓形細胞及白血球ノ浸润ア ע 
小俣武述

(135)

室駼家鬼第 2 號 體重 $2000 \mathrm{~g}$

昭和 3 年 4 月17日手術，4月18日管殺，生存期間 1 日，體重 $1860 \mathrm{~g}$.

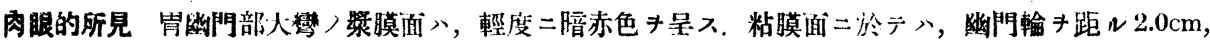

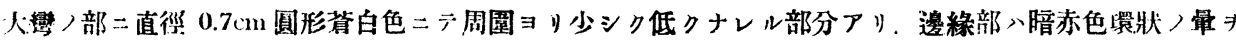

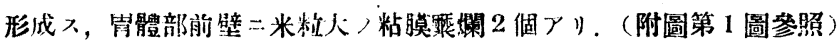

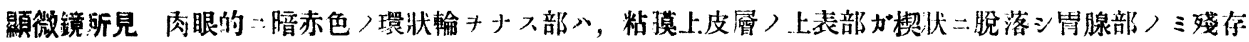

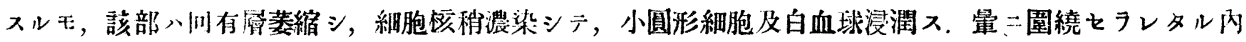

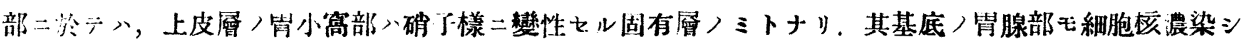

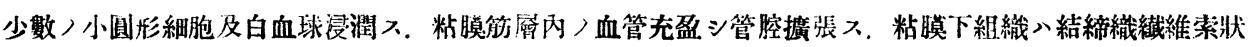

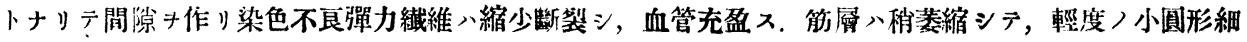

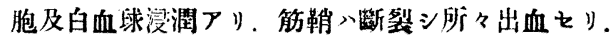

芶驗家鬼第 3 號 體重 $2280 \mathrm{~g}$ 古

昭和 2 年11月29日手術，12月 1 日滔殺，生存期間 2 日, 體重 $2160 \mathrm{~g}$.

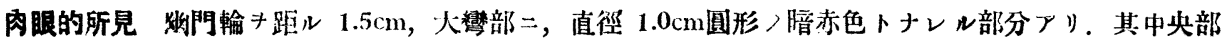

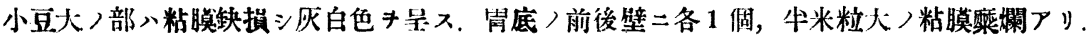

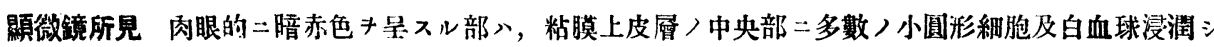

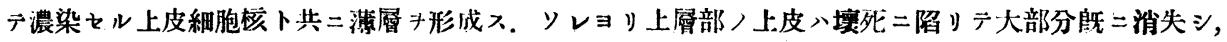

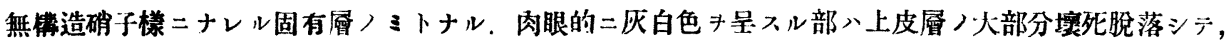

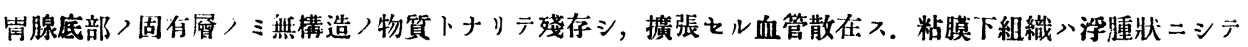

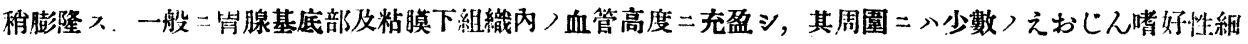

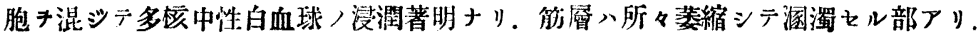

駼家鬼第 4 號 體重 $1970 \mathrm{~g}$ 占

昭和 2 年10月27日手術，10月29日愿殺，生存期間 2 日體重 $1750 \mathrm{~g}$.

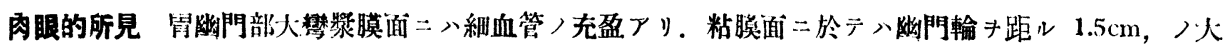

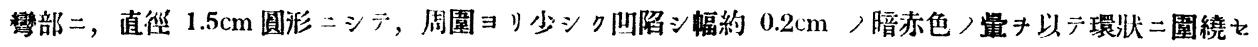

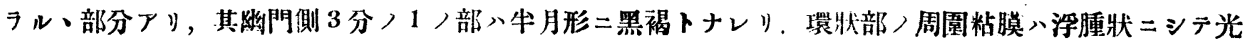
澤ソリ，紐血管軦度二充盈入。岌ノ他部二八著變ナシ。

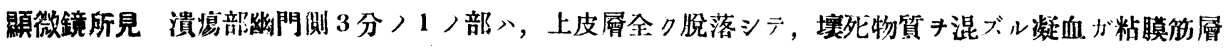

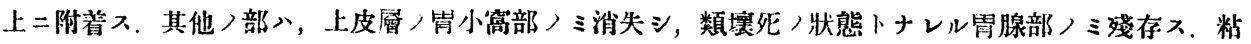

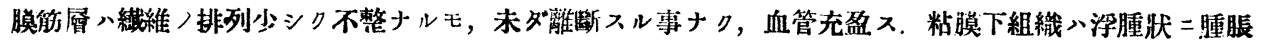

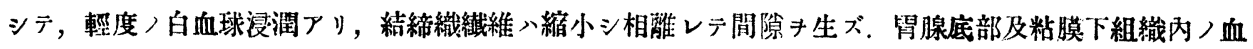
管高度二充盈シ，其周圍二白血球，集筷アリ。筋鹰モ亦浮腫狀キ呈シ所々溷濁セル部アリ筋鞘少シク肥 厚シテ染色不良トナレリ。

咐言 本例ニ於テハ肝藏ニ稍著明ナル組織學的㱍化アリ.郎, 主トシデ肝小葉ノ周邊部二周圍卜ノ境界

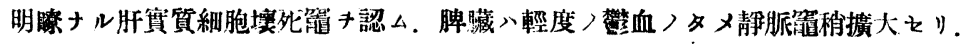

空銥家鬼第 5 㖸 體重 $1880 \mathrm{~g}$

昭和 3 年 4 月17日手術，4月20日看殺，生存期閒 3 日，體重 $1790 \mathrm{~g}$. 


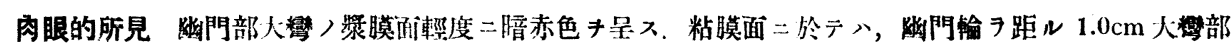

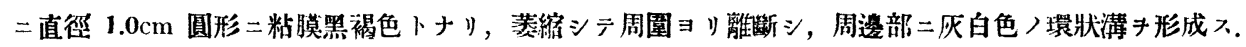

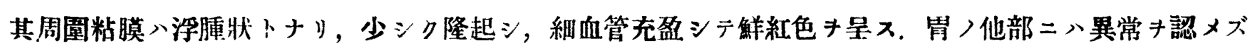
(附圖第 2 圖鱟昭).

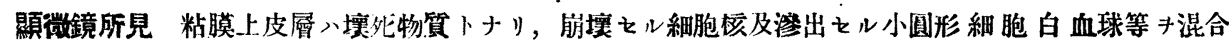

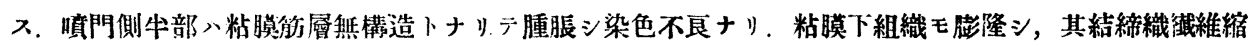

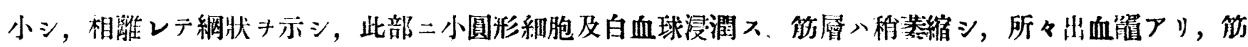
鞘入所々浮腫状二肥厚シテ，膨大入，邊緣部ノ胃腺基底部及粘膜卜組織內/血管充盈入。

贯驗家鬼第 6 號 體重 $2050 \mathrm{~g}$ 우

昭和 2 年10月27日手術, 10 月 30 日屠殺，生存期間 3 日，體重 $1850 \mathrm{~g}$.

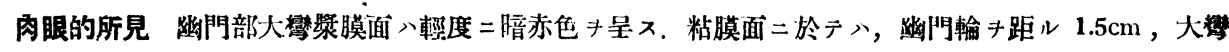

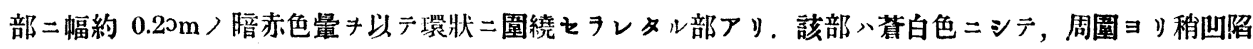

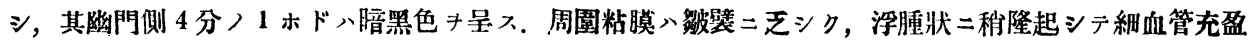
ス. 胃底前壁二米粒大ノ粘膜策爛 1 個アリ。

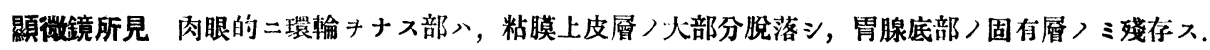

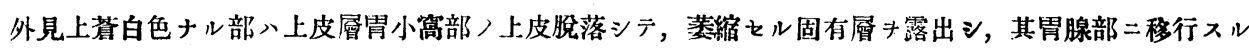

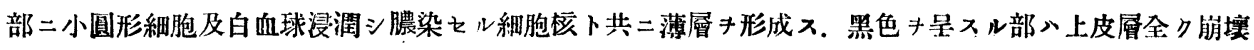

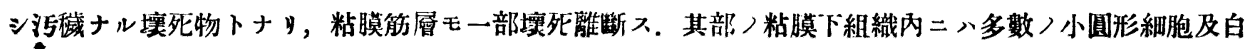
血球集簇ス。其他ノ所見八略前例卜異ラズ.

暂驗家鬼第 7 號 體重 $2030 \mathrm{~g}$ 우

昭和 3 年 4 月 18 日手術，4月22日屠殺，生存期間 4 日，體重 $1820 \mathrm{~g}$

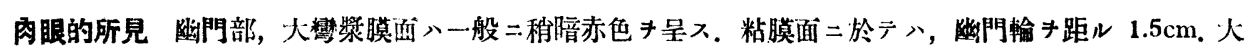

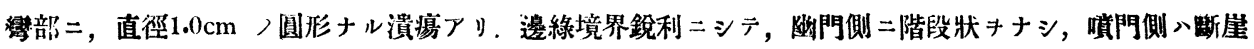

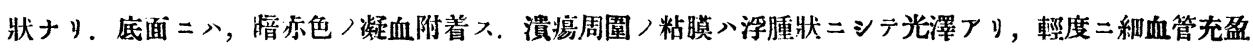

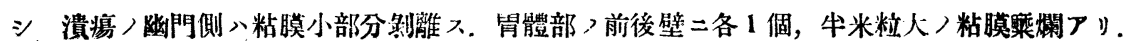

(附圖第 3 圖參照).

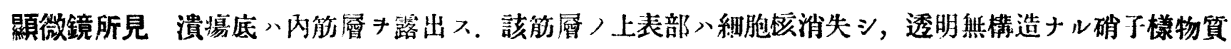

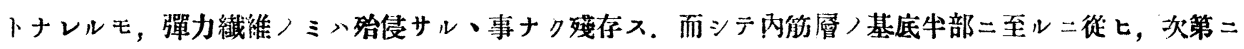

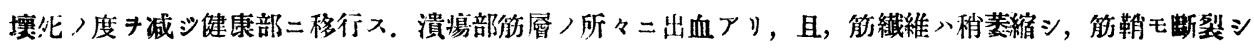

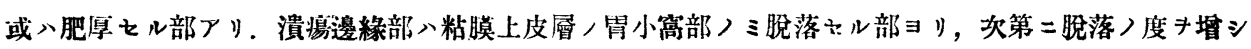

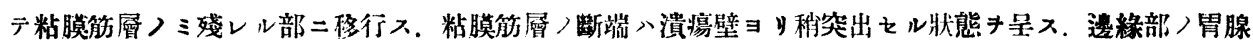
底部及粘膜下組織內 $>$ 血管輕度二充盈入。

雷驗家鬼第 8 號 體重 $2080 \mathrm{~g}$ 우

昭和 3 年 4 月19日手術，4月24日算殺，生存日數 5 日，體重 $1960 \mathrm{~g}$.

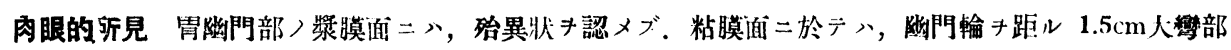

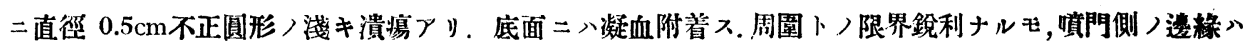

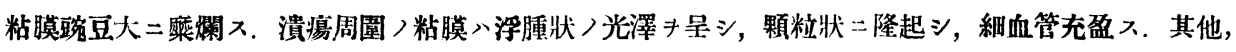




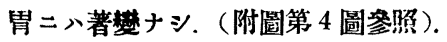

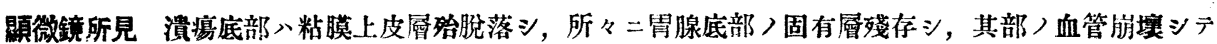

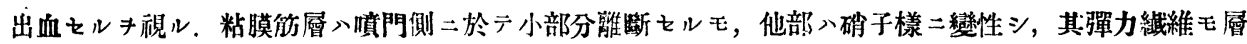

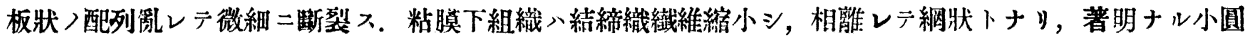

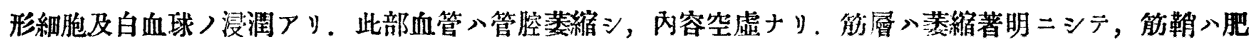
厚断裂シ染色不辰トナリ，䡒度ノ小国形細胞及白血球ノ浸潤アリ。

\section{第 1 項 梗 概 及 考 按}

各實驗動物相互，間二於ヶル，實驗成績ニ多少ノ差違アルハ, 勿論ナレドモ, 余八，以上ノ實噞例ガ示スガ如ク，略，一定ナル潰歾發生ノ初期狀態 得タリト信ズ. 郎, 術後凡ン一書夜ニシテ, 幽門輪 7 距ル 1.0 万至 $2.0 \mathrm{~cm}$ 八大彎

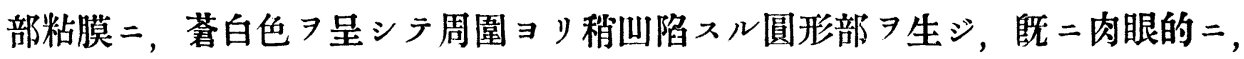

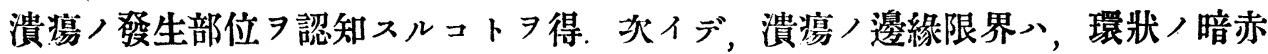

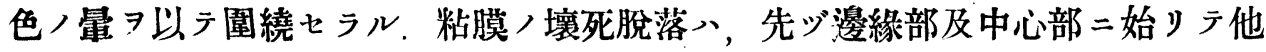
部二及ブモノトス，而シテ，此際，胃腺基底部及粘膜下組織內ノ血管充盈シ。， 著明ナル殹血並二浮腫 術後約引畫夜ニシテ，ソレョリ次第二消退スルト共二，該部八壞死二陷ルラ認 么。粘膜筋層、抗抵力强クシテ，上皮層，大部分脫落シ，浮腫狀二膨隆セル粘 膜下組織ガ著明二壞死現象 7 呈シタル後, 郎, 手術後凡ソ 4 書夜以後二於テ離 斷スルラ以テ，茲二，潰演底八急速二其深少 $\ni$ 增シテ筋層二達スルニ至ル．内 筋層及外筋層二於ル變化、主トシテ輕度ノ萎縮习認ムルニ過ギズ。

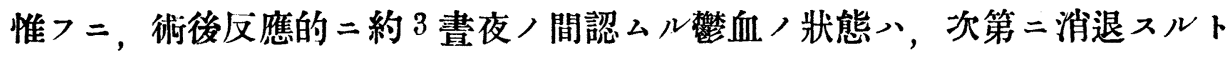
共二, 組織八壤死 $\ni$ 來スモノ、如ク，其際輕度ノ小圓形細胞，多核中性白血球 及少數ノ总おじん㖺好性細胞單核巨大細胞等ノ浸潤 7 見ルモ，一般二甚シキ笑

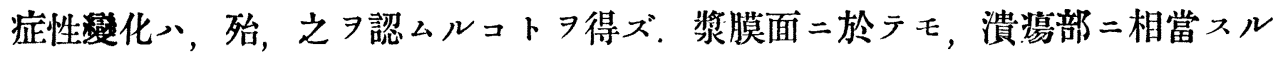
幽門部大彎側、，術後約 3 日迄、細血管充盈シテ暗赤色 $コ$ 呈スルモ，其後次第 二其程度 7 减ジ，約 5 日

潰湯以外，稀二胃體，若ク八，胃底ノ部二，粘膜糜爛 二，其發生部位一定セザルノミナラズ，其組織學的變化モ粘膜上皮層ノミニ限 局シ, 粘膜下組織ニハ何等ノ異㹜 7 呈スルコトナシ. 之ヨ前記ノ如ク潰湯部ガ, 
(138)

圆形胃溃湯形成, 實驗的研究

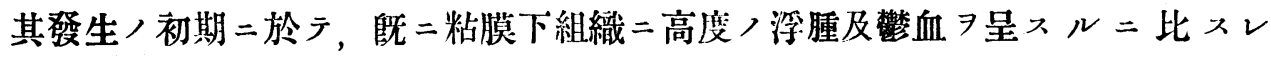
バ，兩者其磼生ノ狀態二，已二明劃ナル成立機轉ノ相違アルタ認ム。

\section{第 2 項 術後 1 週間ヨリ 2 迴間二至ル實駱例}

\section{青驗家鬼第 9 號 體重 $1830 \mathrm{~g}$ 合}

昭和 3 年 5 月 30 日手術 6 月 1 日 ヨリ每日 1 回 5 日閒 $4.0 \%$ りちおんからみん波注射 $3.0 \mathrm{cc}$ ヨリ次第二 增量シテ 6.0 cc ニ至ル, 6 月 6 日着殺, 生存期間 7 日, 體重 $1600 \mathrm{~g}$.

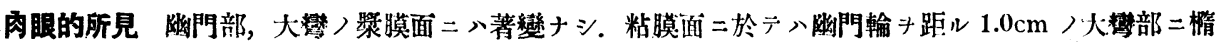

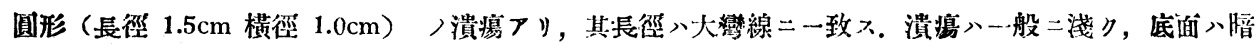

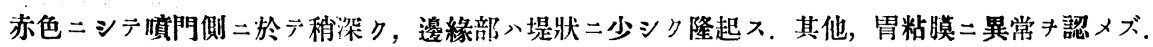

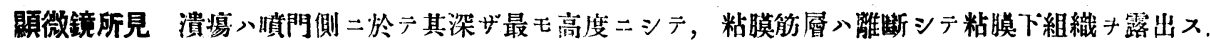

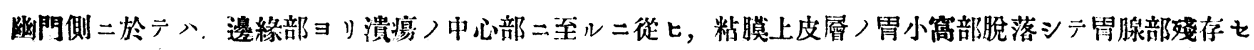

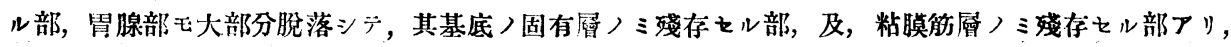
以ラ階段狀キ呈ス，邊緣部〉粘膜上皮層八固有層浮腫狀トナリ。其內二所々出血霆アリ，而シテ散在性

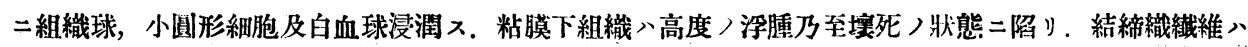
菱縮シテ核入膿染シ所々出血アリ，組織球小四形細胞多核中性白血球及小數ノえおじし啫好性細胞浸润

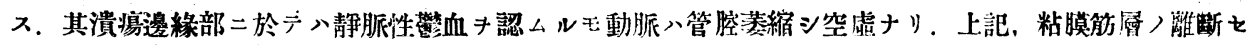

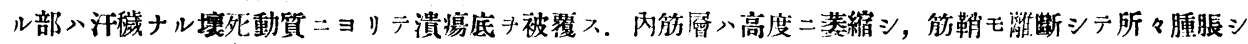
小圆形細胞及白血球ノ浸洞アリ。

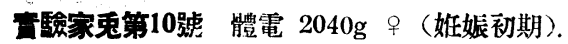

昭和 3 年 2 月 9 日手術, 2 月 16 日自然死，生存期間 7 日，體重 $1680 \mathrm{~g}$.

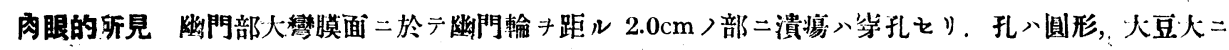

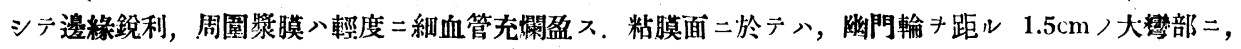

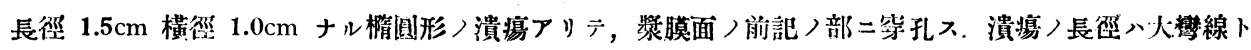

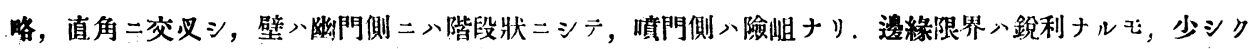

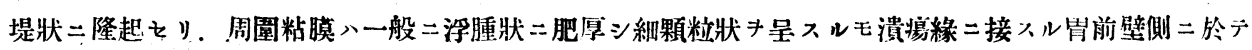

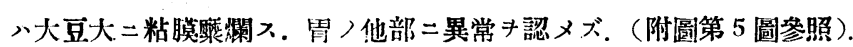

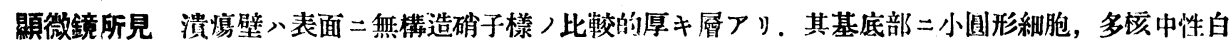

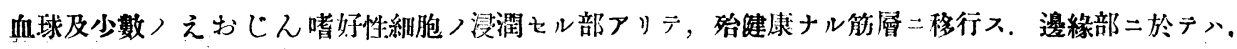

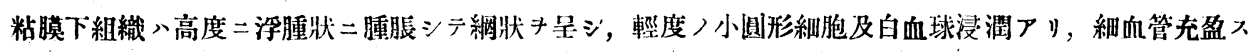
粘膜上皮層八固有層䓠縮シ，其基底部二八細血管)充盈つリ。(附圖第13圖参照).

空驗家鬼第11號 體重 $2100 \mathrm{~g}$ 宁(婎娠中期).

昭和 3 年 2 月 15 日手術, 2 月 22 日自然死，生存期間 7 日, 體重 $1980 \mathrm{~g}$.

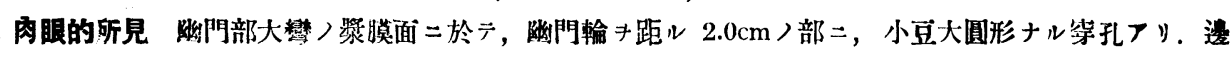

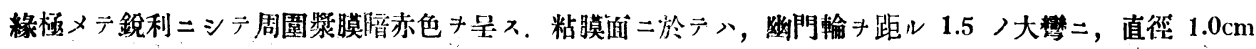

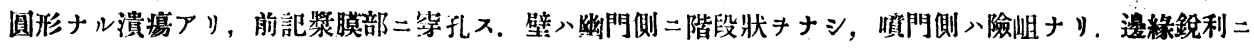


小俣武述

( 139 )

シテ，周圍粘膜浮腫狀二腫脹シ細血管輕度二充盈入。胃ノ他部二異常キ認メズ。

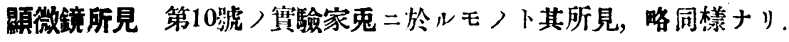

騟家鬼第12號體重 $1690 \mathrm{~g}$ 古

昭和 2 年11月 7 日手術，11月14日自然死，生存期間 7 日，體重 $1250 \mathrm{~g}$.

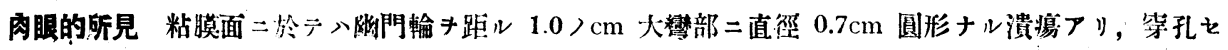

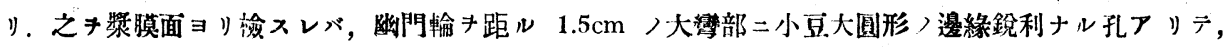

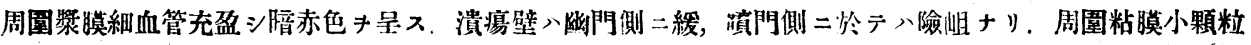
狀二隆起 ス.

顯微鏡所見 第10號ノ實驗家兔ニ於ヶル潰場卜其所見，路同樣ナタ．

驗家鬼第13號 體重 $1870 \mathrm{~g}$ 方

昭和 3 年 1 月 26 日手術, 2 月 2 日搌殺，生存期間 8 日，體重 $1710 \mathrm{~g}$

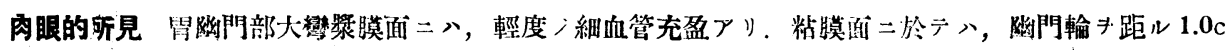

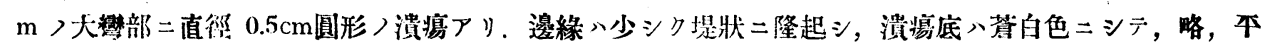
滑ナルモ，幽門側二於テハ階段爿キナシ，幽門測二於テハ最モ深クナリ．且，其部ニテハ潰場邊緣下二

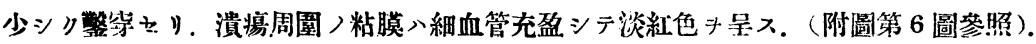

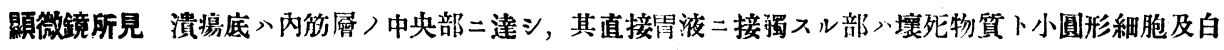

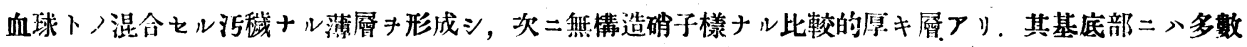

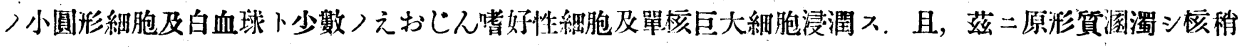

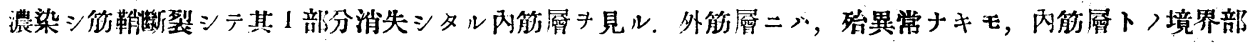

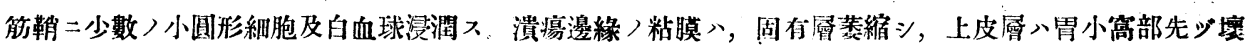

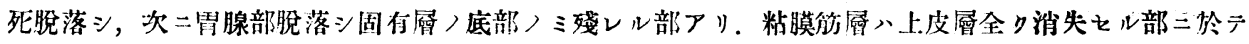

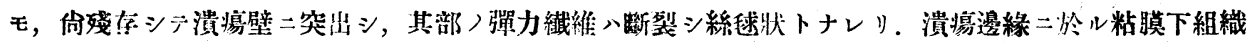

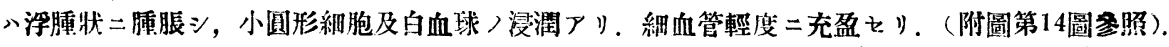

青驗家鬼第14號 體重 $2340 \mathrm{~g}$ 우

昭和 2 年10月5 日手術，10月13日屡殺，生存期間 8 日，體重 $2090 \mathrm{~g}$.

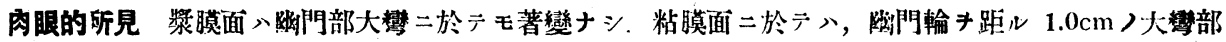

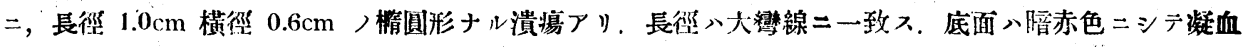

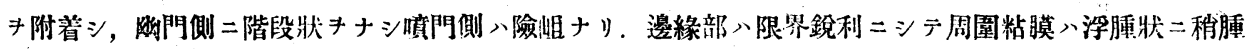
脹シ細血管輕度二充盈ス。其他, 胃ノ他部二異常斗認メブ。

㩆微鏡所見 第13號，賽驗家兔二於ケル潰瘍卜其所見，略同樣ナリ。

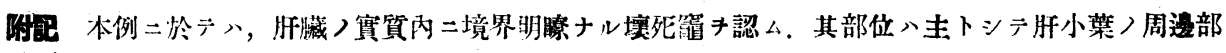
$=>$ I.

考驗家鬼第15號體央 $1870 \mathrm{~g}$ 方

昭和 2 年10月10日手術，10月19日厝殺，生存期間 9 日，體重 $1650 \mathrm{~g}$.

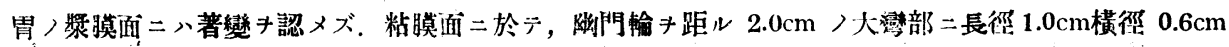

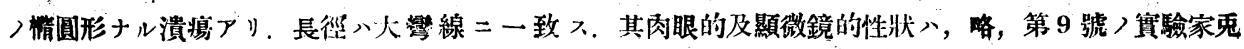


ニ於ケル潰瘍卜同栐ナリ。其他胃ノ他部二異常キ認メズ.

責驗家鬼第16號 體重 $2350 \mathrm{~g}$ 令

昭和 3 年 2 月 1 日手術, 2 月11日壓殺, 生存期間 10 日, 體重 $2090 \mathrm{~g}$.

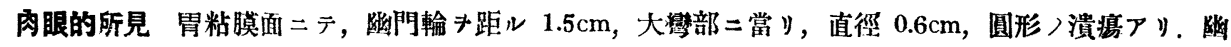

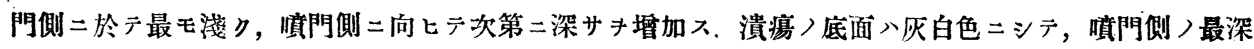
部二於テハ暗赤色ナり，邊緣〉限界銳利ニシテ，其部ノ粘膜少シク堤状二隆起シ，之二續り周圍ノ粘瞙

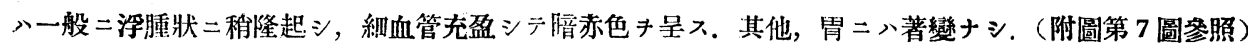

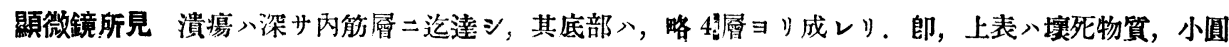

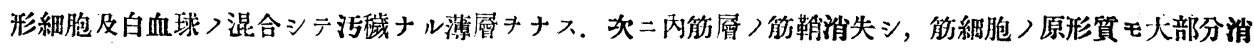
失シテ其核濃染セル部アリ。茲二多核中性白血球，えおし人啫好性絧胞及少數ノふらすま細胞浸润七り

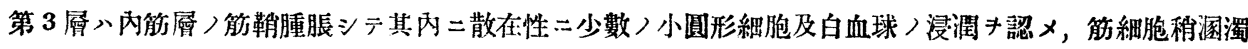

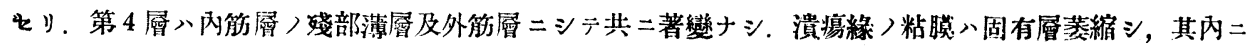

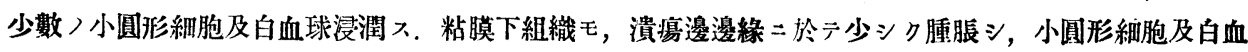
球散在性二浸潤七り。其內）細血管㫫度二充盈入。(附圖第15圖參照).

督驗家鬼第17號 體重 $2030 \mathrm{~g}$ 。

昭和 3 年 2 月11日手術，2月22日屠殺，生存期間11日，體重 $1985 \mathrm{~g}$

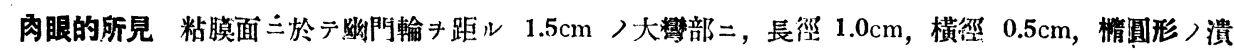

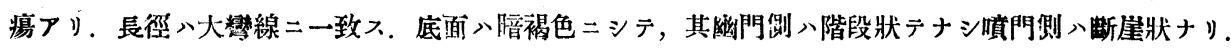

邊緣八限界銳利ニシテ，周園粘膜小顆䊉㹜二隆起入，其他，胃ノ他部二異常ナシ．

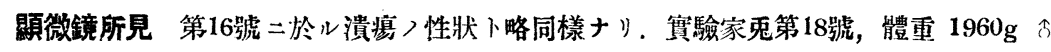
昭和 3 年 1 月 27 日手術，2月12日啳殺，生存期間 14 日，體重 $1900 \mathrm{~g}$.

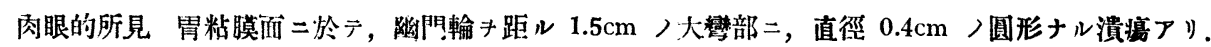

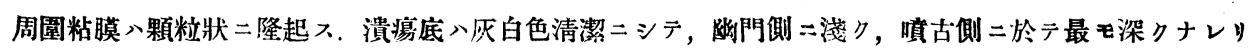
其他胃二異常キ認メズ（附圖第 8 圖參照).

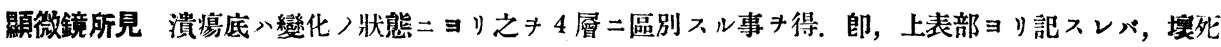

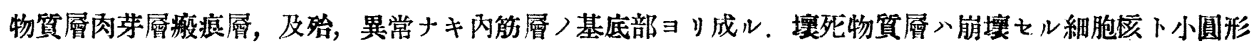
細胞及白血球卜ノ混合セルモノョリ成り，此較的薄層二シテ，其基底部二分界線キ形成シ，肉芽展卜明

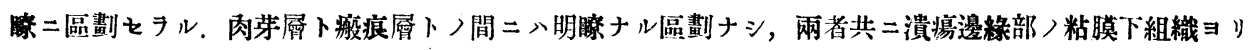

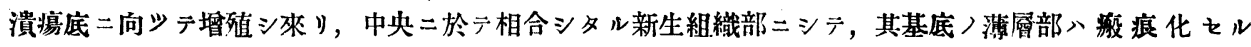
モ，表面部、向，幼若ナル結締織細胞二富ミ，該細胞間二散在性二小圓形細胞及白血球ノ浸潤アリ，且，

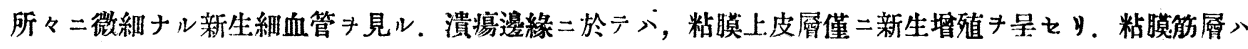

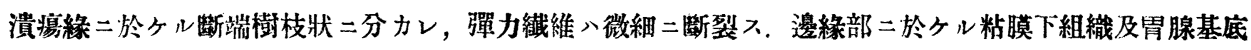

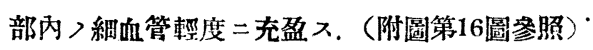

雷驗家鬼第19號體重 $2300 \mathrm{~g}$ 。

昭和 3 年 1 月 18 日手術，2月 1 日畨殺，生存期間 14 日，體重 $2150 \mathrm{~g}$.

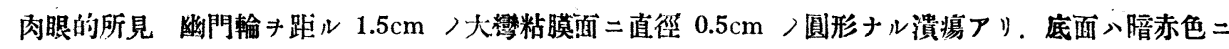

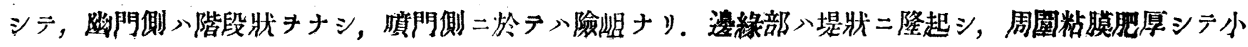


小俣武述

$(141)$

顆粒状キ呈ス，其他，胃二著變ナシ。

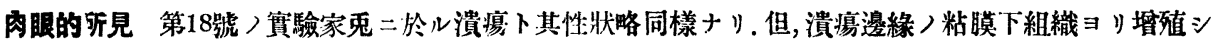

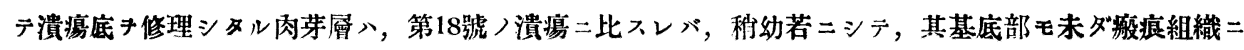
訤化せで.

雷駼家鬼第20㗔 體重 $2320 \mathrm{~g}$ 。

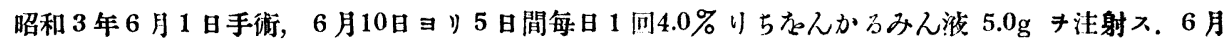
15 日屠殺，生存期間 14 日，體重 $2220 \mathrm{~g}$.

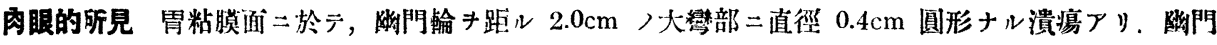

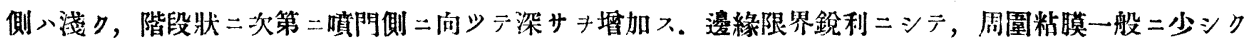
肥厚ス. 胃ノ他部二ハ異常斗認メズ.

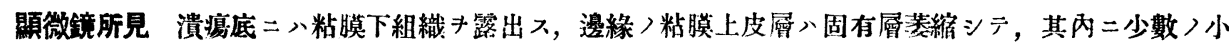

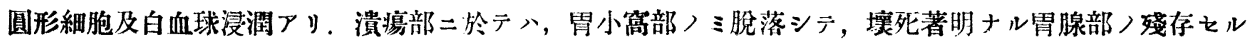

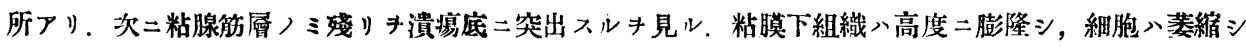

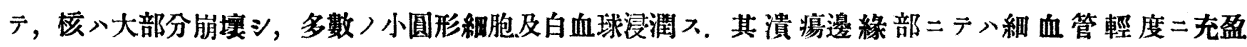

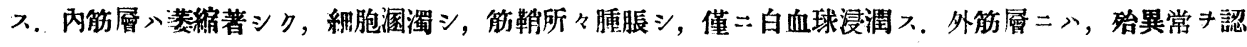
メズ.

雷驗家鬼第21號 體重 $2000 \mathrm{~g}$ 今

昭和 3 年 6 月 22 日手術， 7 月 6 日屡殺，生存期間 14 日，體重 $1770 \mathrm{~g}$.

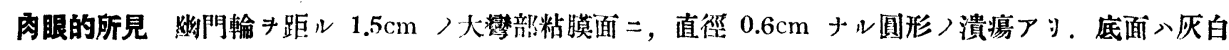
色コシテ，比較的清潔ナリ，幽門側二於デ階段狀キ虽シ，償門側八断崖狀キナス，邊緣堤狀二隆起シ 周圍粘膜 八細顆粓狀二肥厚ス。胃つ他部二八黑常キ認メズ. (附圖第 9 圖參照).

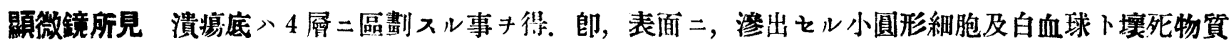

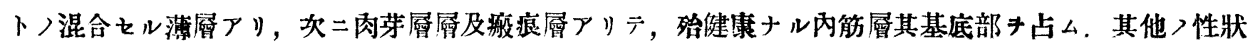

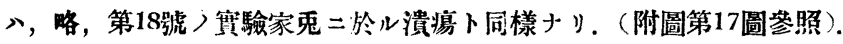

\section{第 2 項 ノ梗 概 及 考 按}

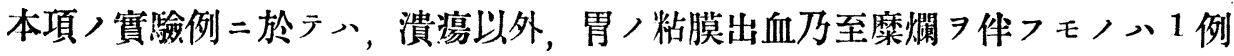
モ無シ，蓋シ，出血乃至糜爛八，極メラ迅速二治瘾スルモノニシテ，既 $=1$ 週 間习經過スル時ハ，總ラ全治シ消失セリ，潰場ハ第 1 項ノ實驗ニ於ケルモノニ 比スレバ，邊緣限界銳利トナリ，潰掦底ノ深サハ 7 日乃至 10 日ニシテ，最モ 高度トナル，周圍粘膜二於ケル，細血管充盈ノ程度モ日 $习$ 經ルニ從七其度 $尹$ 减 シ, 術後約 10 日 7 經過スレバ, 殆, 既ニ之ヨ認ムルコトヨ得ズシテ, 欢第二顆

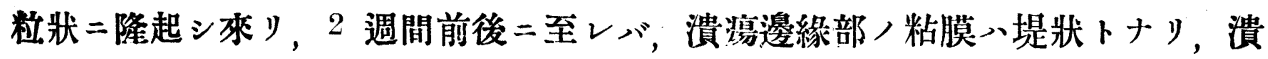




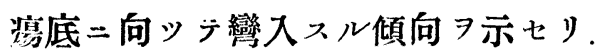

潰場，穿孔七ルモ>3例（第10號，第11號，第12號） 見タルガ，其內 2 例 （第10號，第11號）八，婎㖘家鬼ナリシハ興味アル事實ナリト思惟ス。

組織學的ニ八，手術後約 10 日迄入，潰場》其進行スル像 7 呈シ，潰場壁及底 部，表面二八，滲出セル小圓形細胞及白血球卜壞死物質卜／湜合セル帶狀／溥 層アリ，次層二壞死現像著明ナル部アレドモ，表層 $コ$ 遠ザカルニ從七，次第二其 度习减シ，明暸ナル區劃ナクシラ，殆異常ナキ筋層二移行入，潰場底》內筋層 二達シ, 若クメ, 該筋層ノ中央部二達スル鹪合多シ，邊線部上皮層二於テハ，先

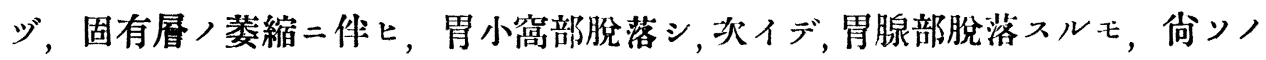
基底部固有層八殘存スルモノアリ，粘膜筋層八抵抗力極メラ强》，從テ，上皮 層习全ク失へルトコロニテハ，之レガ潰营底二向ッテ突起シ，其先端及表面ヨ リ次第二壊死崩壤スル像 壤スルモ八、如ク，潰場邊線部二於テン，其內八細血管充盈シ，術後 10 日以後

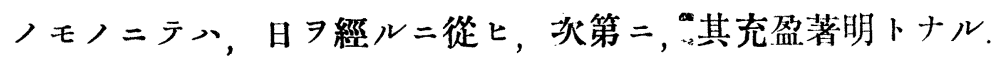

手術後 10 日乃至 2 週間 二至レバ, 潰瓷入䊑治癒ノ傾向 ヨ示スモノアリ（第18

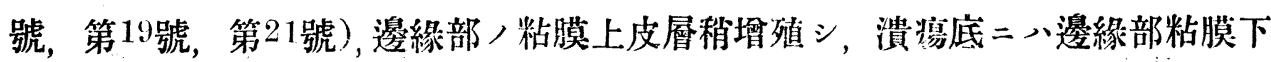
組織ヨリ，肉芽組織增殖シ承リテ，之 修理シ，其表面八少幼若ナル結締織細

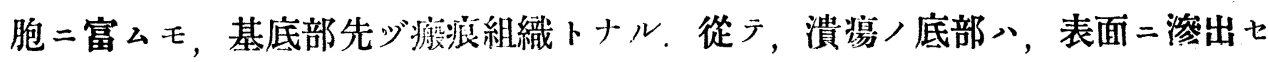
ル小圓形細胞及白血球卜壞死物質トヨリ成レル薄層アリテ，肉芽層，洀泿層之 二亞ギ，基底部八，殆異狀十キ筋層ョリ成ル二至り，恰，人類慢性胃潰榢八組 織學的所見卜同樣, 像 $尹$ 呈ス。

\section{第 3 項 術後 3 週間 $コ$ J 5 调間ニ至ル竇䮄例}

\section{需驗家鬼第22线 體重2000g 。}

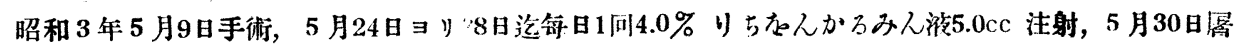
殺，生存期間21日，體重 $1740 \mathrm{~g}$.

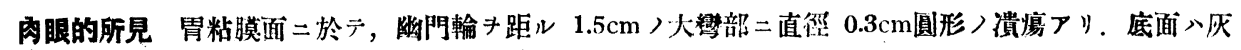

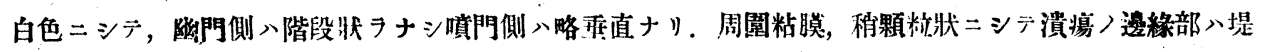
狀二隆起入. 胃ノ他部ニハ異常ナシ。

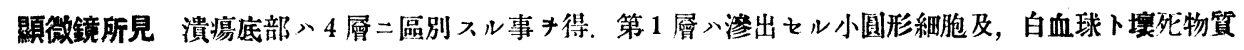

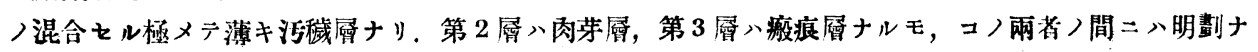


小俣武述年

ル限界ナク，基底，小部分ノミ全ク般痕化シテ，上表二移行スッニ從光幼若ナル肉芽組織トナレリ， 肉芽組緎內二八新生細血管多》, 其周園組㵶內二八散在性二小但形細胞, 多核中性白血球, 組織球及七゙

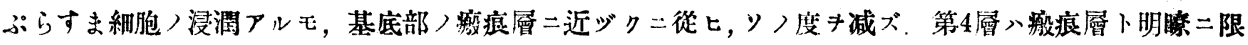

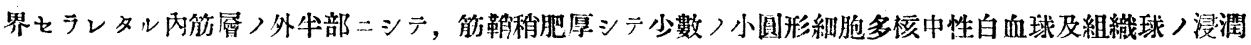

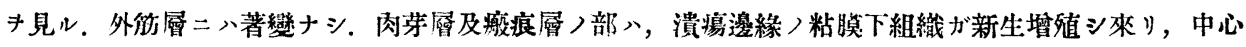

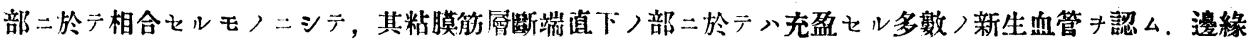

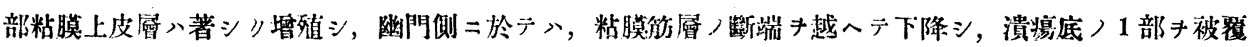

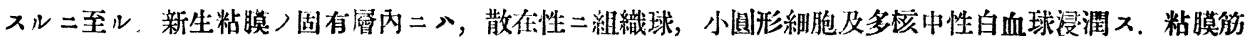
算ハ增殖ノ傾向キ示サブ。

\section{贯駼家鬼第23號 體重 $1925 \mathrm{~g}$ ？}

昭和 2 年9月20日手術，10月11日瘄殺，生存期間21日，體重 $1920 \mathrm{~g}$

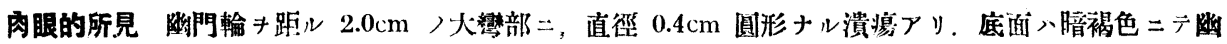

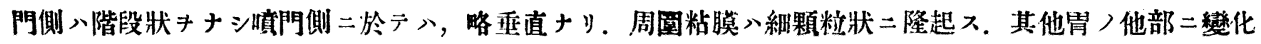
ナシ. (附圖第10圖參照).

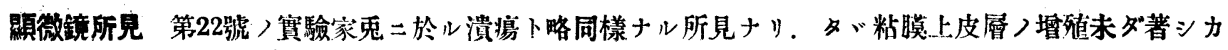
ヨブシテ，漬境壁キ下降スルニ公ラザル點二於デミ，多少相異ナレリ。(附圖第18圖參照).

富驗家鬼第24號 體重 $2160 \mathrm{~g}$

昭和 2 年 9 月22日手術，10月13日蹷殺，生存期間21日，體重 $1960 \mathrm{~g}$.

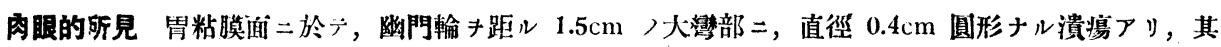

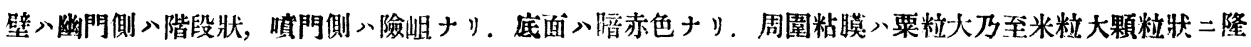
起シ，邊緣部二於テ八堤狀二隆起入。其他. 胃二著變ナシ。

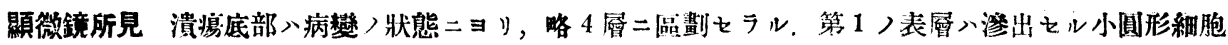

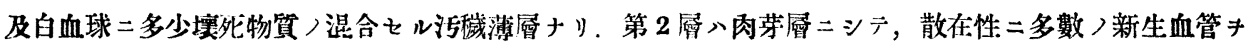

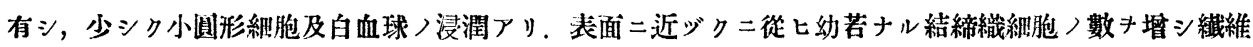

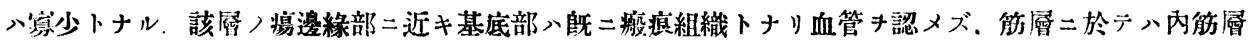

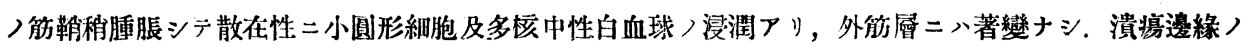

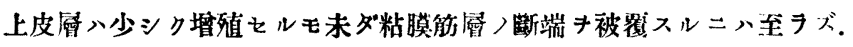

空驗家鬼第25號體重 $2050 \mathrm{~g}$ 合

昭和 2 年 9 月 25 日手術，10月16日屠殺，生存期閒21日，體重 $1830 \mathrm{~g}$.

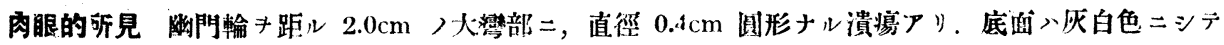

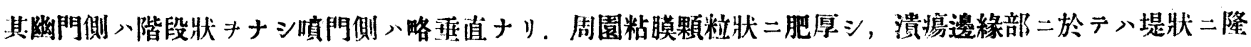
起ス. 胃ノ他部ニハ異常ナシ.

影微鏡所㫕 第24號ノ賽驗例二於ルモノト，略同榡ナリ。

等驗家鬼第26號 體重 $1890 \mathrm{~g}$ ㅇ

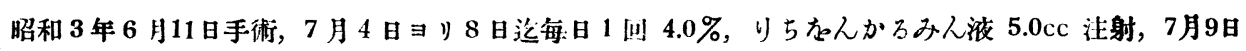
啳殺，生存期間 28 日，體重 $1630 \mathrm{~g}$. 
肉眼的所見 胃粘膜二於テ，幽門輸キ距ル $2.0 \mathrm{~cm} /$ 大㩯部二潰場アリ。周園粘脱顆粒狀二高度二隆起

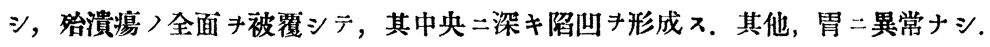

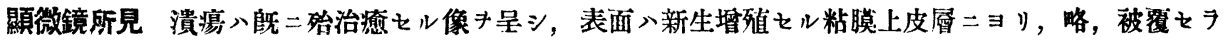

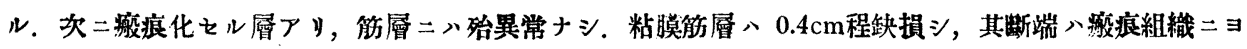

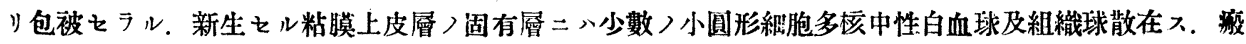
痕組織〉上表牛部二八向, 幼若結締織細胞及新生細血管アリテ，其周圍組織內二散在性二小數ノ白血球 及組織球浸润入。粘脱笳層斷端部二於テ粘膜下組織内 $/$ 血管高度 $=$ 充盈 7.

传驗家鬼第27號 體重 $2290 \mathrm{~g}$ 方

昭和 2 年10月1日手術，10月31 日撛殺，生存期間30日，體重 $1970 \mathrm{~g}$.

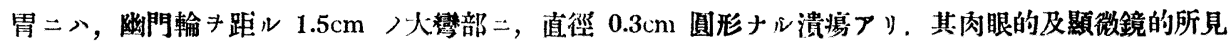
ハ，略，實驗家兔第 22 號二於ルモ>ト同棣ナリ。

害驗家鬼第28號 體重 $1870 \mathrm{~g}$ ㅇ

昭和 2 年10月 2 日手術，11月4日曆殺，生存期間33日，體重 $1780 \mathrm{~g}$.

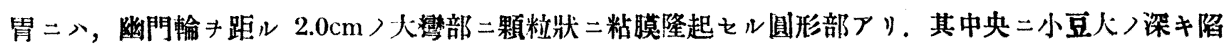
凹キ見ル。其肉眼的及組織學的所見ハ，略，第 26 號ノ賽驗例二於ルモ，卜同樣ナリ。

算驗家鬼第29號 體重 $1940 \mathrm{~g}$ 令 昭和 2 年 10 月 2 日手術，11月 5 日屠殺，生存期間 34 日，體重 $1850 \mathrm{~g}$.

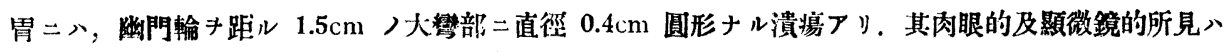
第24號ノ賽驗家鬼二於ルモノト，略同樣ナリ。

\section{雷驗家秉第30號 體重 $2640 \mathrm{~g}$ 古}

昭和 2 年 9 月 20 日手術, 10 月 26 日屠殺, 生存期間 36 日, 體重 $2200 \mathrm{~g}$.

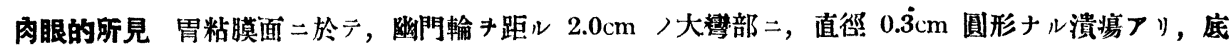
面八増赤色キ呈シ，其幽門側ハ階段狀キナシ蔀門側ハ最モ深クナレリ．周圍粘膜著明二顆粒狀二隆起 ‥ (附圆第11圖胗照).

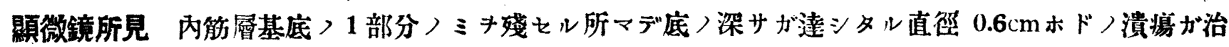

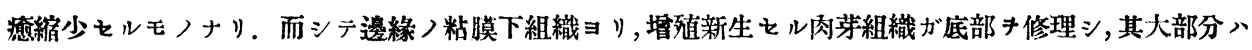
既二洀痕組織トナリ，表面二近キ部分ノミ幼若ナル結締織細胞散在入。而シテ直接胃波二接斶スルル面二

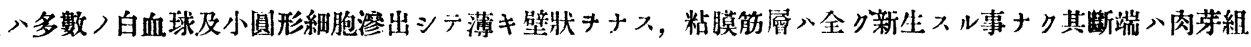
織ニョリ包被セヨル。(附圖第19圖參照).

\section{第 3 項 ノ梗 概 及 考 按}

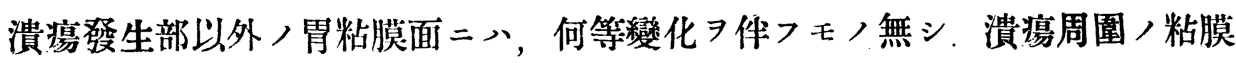
八，著シク顆䊀㹜二隆起シ，ソノ細血管ハ輕度二充盈スルモノ多シ．殊二，潰 
凜邊緣部, 粘膜高度二顆粒狀二隆起シ, 潰韵壁二彎入スルニ至ルガ故二, 潰場 八縮小スルト共二, 邊緣銳利ナラザルニ至ル。術後約30日 7 經過シタル實驗例

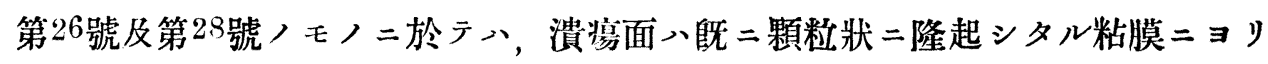
全ク被罂セラレ，僅二其中心部ニ小ナル陷没部 留ムルニ過ギズ.

組織學的二八，潰演底部入其表面二渗出七ル小圓形細胞及白血球卜壞死物貿 トノ混合セル活穢ナル薄層アリ。次二,肉芽層及撚泿層アリテ, 基底部入著シキ 變化ナキ筋層ヨリ成り，其所見，殆，前記 2 週間前後，實驗例卜同樣ナリ。但，

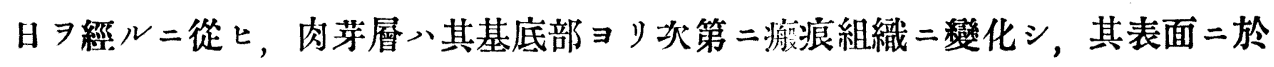
ケル壤死物質ハ减少シテ, 沴出七ル小圓形細胞及白血球ノミョリ成ル薄層 7 形 成ス。粘膜筋層八全然堦殖スルコトナク，新生セル粘膜上皮層八直接肉芽首 被㠅入. 前記, 實驗例第 26 號及第 28 號, 如ク，特二手術後約 30 日 7 經タルモノニ テハ，潰場底面ガ新生セル粘膜上皮層二依り全ク被稪セラレタルヨ見ルモ，

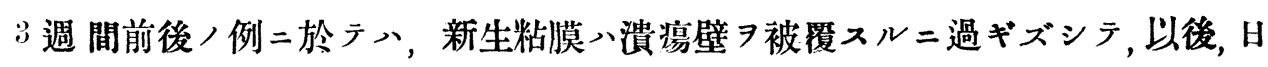

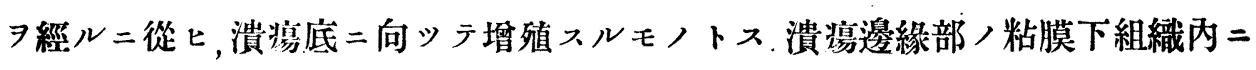
、多数, 細血管新生集簇シ, 且, 充盈入。肉芽層内二モ多數/新生細血管 7 認 ムルモ，其次第二洀泿組織二變化スルニ從七血管ハ消失ス。

\section{第 4 項 術後10週間以後ノ實騟例}

贺験家鬼第31號 體重 $2460 \mathrm{~g}$

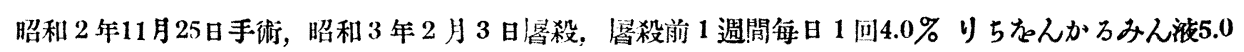
$\mathrm{mc}$ 注射入, 生存斯阳 70 日, 體重 $2350 \mathrm{~g}$,

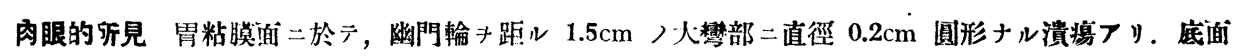
八暗赤色キ呈シ，周圍粘膜八隆起シ顆精狀キ呈ス. 胃つ他部二八異常ナシ。（附圖第12圖參照）

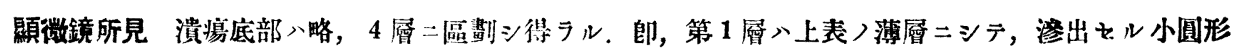
細胞及白血球ヨリ成y，第 2 層八肉芽層ニシテ，幼若ナル結䋨織細胞二富ミ，處々二新生細血管キ認メ，

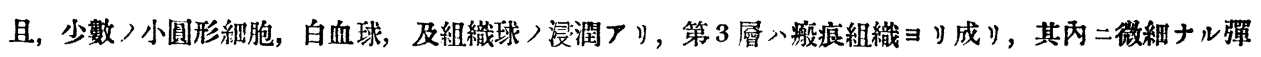

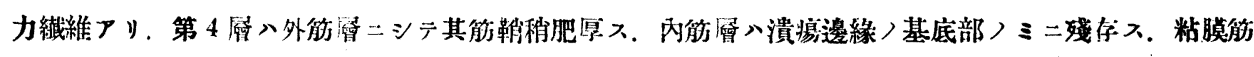

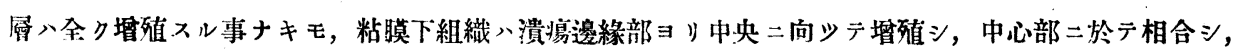
其基底部八般症組織トナレルモ，上表部八佾肉芽組織ナリ。從テ新生增殖セル粘膜上皮層八直接該肉芽

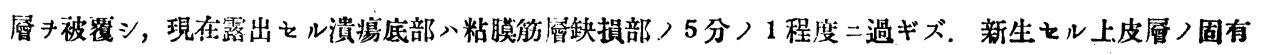


犚八高度二肥厚シ，此部二播種狀二多數 ，小国形細胞，多核中性白血球及組織球浸润入，粘膜筇層断端 部ノ粘膜下組織ハ稍肥厚シ。多數ノ充盈セル細血管アリ。(附圖第20圖參照).

空駼家鬼第32號 體重 $2130 \mathrm{~g}$ 。

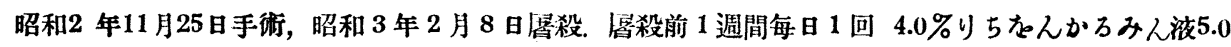
cc注射入。生存期間75日，體重 $1950 \mathrm{~g}$

内眼的所見 胃粘膜面二於テ，幽門輸斗距儿 $1.0 \mathrm{~cm} /$ 大彎部二，直鮇 $1.5 \mathrm{~cm}$ 圆形腤赤色二テ颗稙狀 キナセル粘膜部アリ。其中央部二不正圆形米粗大ノ深キ䧂沺アリテ，邊緣ノ粘膜ハ堤狀二隆起シテ，漏

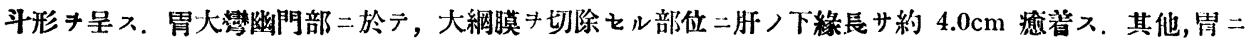
異常ナシ.

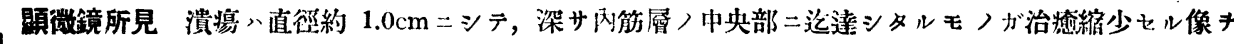

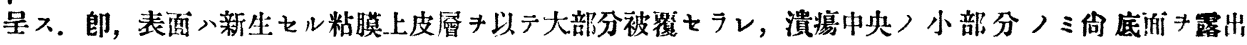
ス. 新生七ル粘膜上皮層入固有層八肥厚著シク彈力㵶維ハ之キ卧キ，散在性二小圆形細胞多核中性白血

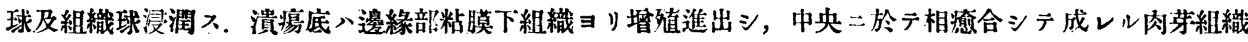

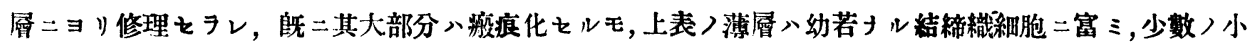

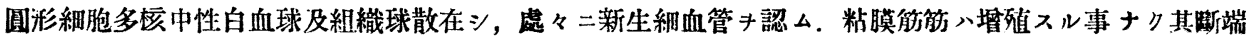

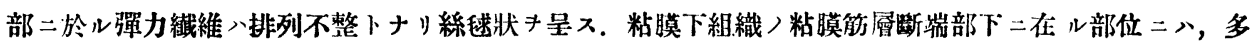

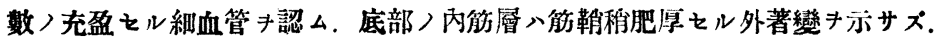

空驗家鬼第33躆 體重 $1850 \mathrm{~g}$ ㅇ

昭和 2 年11月10日手術，昭和 3 年 2 月 10 日屡殺，生存期間 92 日，體重 $1780 \mathrm{~g}$.

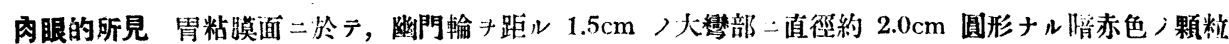
狀粘脱隆起アリテ，其中央牛米粒大入部八深》㫟沒、。

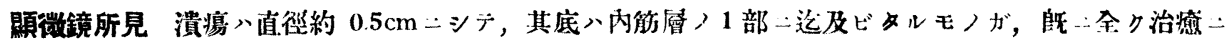

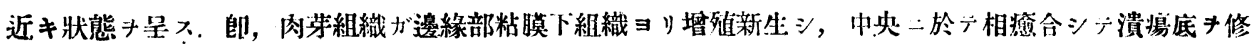

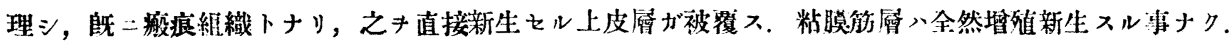

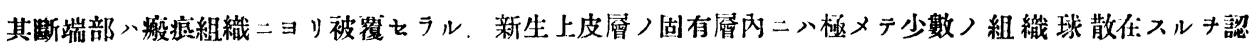

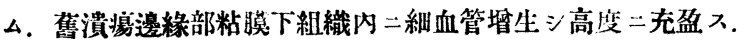

\section{第 4 項 梗概 及考 㨉}

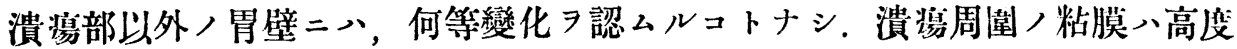
二顆䊀狀隆起 7 來シ，殊二，邊緣部二於テ著シク隆起シ，潰瘍壁二彎入シテ之 ７被包ス，實驗例第33號二於テハ，顆䊀㹜二隆起七ル粘膜ノ中央部二，小ナル 陷凹 7 呈スルニ過ギズ. 


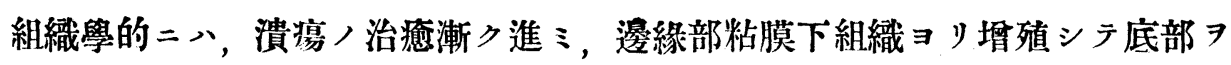
修理スル肉芽層ハ，其大部分既二㜍泿組織トナレリ。直接胃液二觸ルル表層八 壤死物質减少シ，殆，渗出セル小圓形細垉及白血球：ミョリ成ルニ至り.或八, 既二該屑消失シテ肉芽層 7 露出入，粘膜筋屏八全然增殖新生スルコトナリ，其

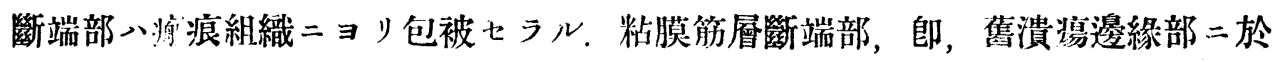
ケル粘膜下組織內二八，多數ノ充盈セル細血管墦殖ス。新生セル粘膜上皮層八，

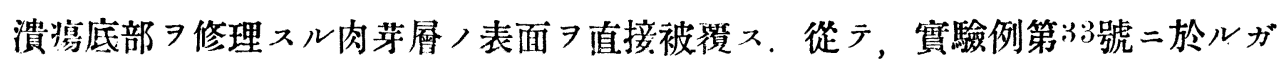
如ク, 溃貊全治/狀態トナリテ, 該肉芽層全ク痛痕化スルニ至レバ, 其容積縮

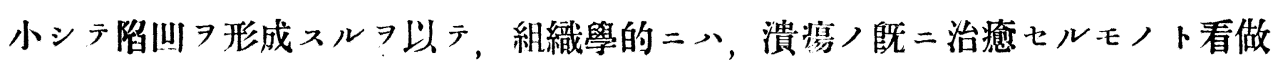
サル、モノ二於テモ，肉眼的二八，一見，潰暢ノ現存セルガ如キ狀態 7 呈ス。

\section{（5）第 1 章二於尔儿實騟成精ノ總括及考按}

上記，如ク,余八, 33 例，賽驗動物二於广，常二例外ナク，必發的二，幽門輪 7 距ル1.9 乃至 $2.0 \mathrm{~cm}$ ，大彎部二, 略, 定型的ナル胃圓形潰嫁 $タ$ 形成セシムルニ成 功シタリ。該潰崲ノ形状入, 圓形(值徑 0.5 万至 $1.0 \mathrm{~cm}$ ) 若ク八, 㒂圓形（長徑 1.0 乃至 $1.5 \mathrm{~cm}$ ，橫俓 0.4 乃至 $0.7 \mathrm{~cm}$ ) 二近》，基底部八筋層二達シ，潰場壁八幽

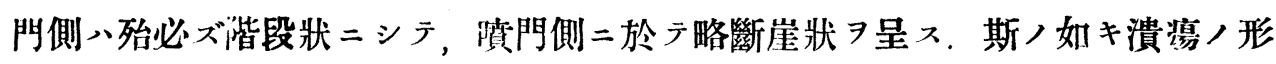

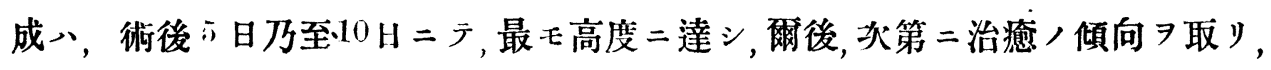
最短 1 ケ月, 長キハ3 ケ月ニシテ漸ク全治ス。潰場以外, 稀二胃粘膜二出血乃至 糜爛 伴フコトアルモ, 該變化・數日ニシテ治瘾シ, 手術後 1 週間 7 經タル實 驗例二於テン，全然之 7 認ムルコトナシ，其組織學的所見二據ルモ，此粘膜糜

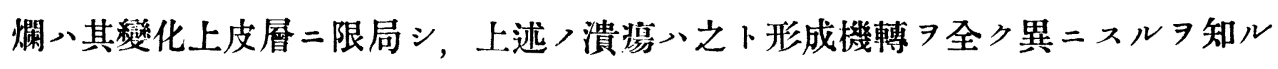

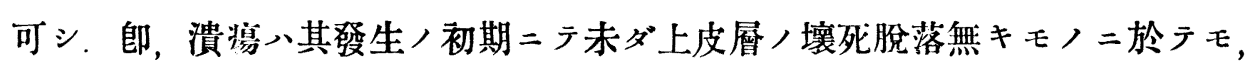
粘膜下組織二, 先ヅ, 著明ナル浮腫狀腫脹 本タシ, 後, 其變化高度トナリ, 若クン，䱋死症状 $尹$ 呈スルニ及ビテ，始メラ粘膜筋層ガ離斷セラルルニ至ル。

潰場部, 組織學的檢索二據レバ, 手術後入該部ノ血管高度二充盈シ, 組織》

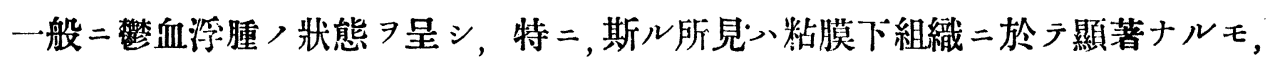

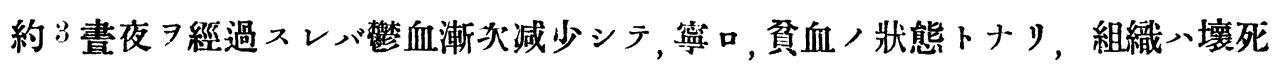
二陷ルニ至ル。其際, 反應的二輕度ノ小圓形細狍及白血球ノ浸潤 7 認ムルモ, 强 
度ノ咨症性變化卜看做ス可キモノハ，之ア認ムルコトナシ，而シテ，潰場ノ型

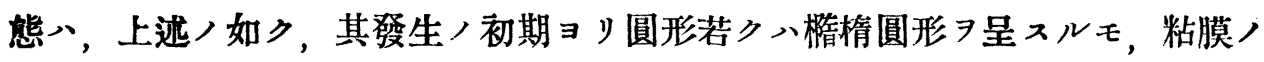

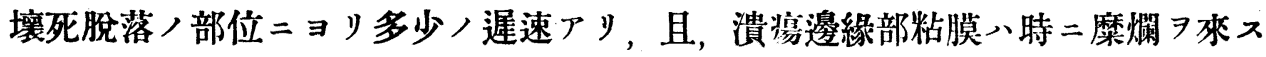
ガ故二，潰場ノ淮行中二入，稍不規則ナルガ，其進行停止シ，或》，稍治瘾機

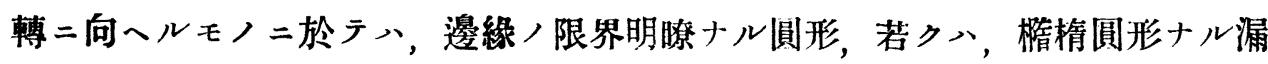
斗状 $\ni$ 呈シ，其立軸ハ斜行シテ，Virchow 氏>所謂定型的構造 7 取ルニ至ル。

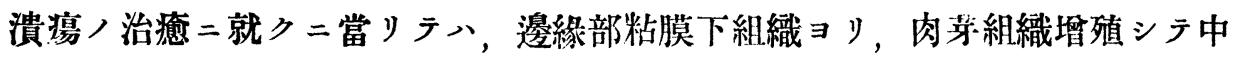
央二於テ相合シ，以テ底部 7 修理シ，其表層八新生七ル粘膜上皮層ガ直接被複

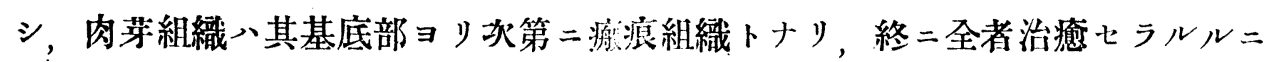
至ル．此際，粘膜筋層八周圍組織二比シ，障礙二對スル抵抗力强》，而力 $E$,

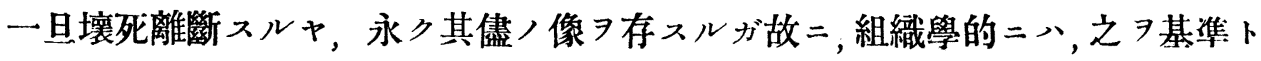

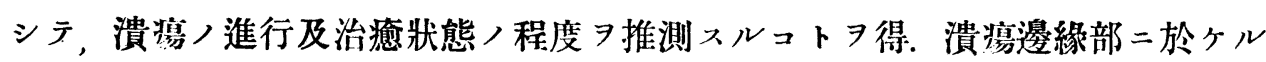
粘膜固有層八基底部及粘膜下組織內 血管入, 手術後約: 月間八高度二充盈 ルモ其後次第二其度 $コ$ 减ジ，管腔，殆，空虚トナリ。潰場治癒ノ傾向 7 取ル ト共二, 再ビ充盈ス。血栓形成・之习認メタルコトナシ。

手術後約 10 日 ヨリ3 週間迄, 實驗例二於儿潰陽入，底部八表面二八渗出七ル 小圓形細胞及白血球卜壤死物質卜ノ混合七儿帶狀, 薄層アリ, 次二, 肉芽層及瘏 浪層アリテ，殆異常ナキ筋層其基底部 7 占ム，而シテ，粘膜上皮層ノ掬殖八著

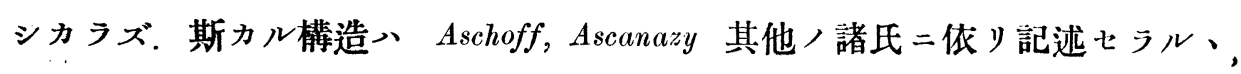
人類慢性胃潰歾ノ所見卜，略，一致スルモノナリ。

上述, 實驗八，在來諸家，研究及余ガ後述セントスル諸實驗二比シ，實驗動 物, 胃及全身状態二與フル障礙八程度, 最モ少ク, 而モ, 確實二一定部位二, 略定型的ナル胃潰㣀 リ。一般二, 大網膜 $\ni$ 胃二近接シテ切除スルモ, 附近藏器, 或入, 腹膜卜胃卜 ノ療著ヨ來タスコトナシ. 此コト八, 從來諸家, 研究ト一致スル所見ニシテ, 最近我國二於テハ波多腰正雄氏ガ, 此關係二就キ研究シ, 其成績 7 發表シタリ.

更二, 余入本章二於ル實驗, 成績二立脚シテ, 其潰陽形成, 原因 7 究メント 欲シ, 次ノ諸實驗 $尹$ 行へリ。 
小俣武迅

(149)

\section{第 2 章 大網膜切除卜胃漬晹發生卜ノ關係}

\section{第 1 篩 文献}

（1）1889 年 Eiselberg 氏八，腹腔内手術後發生セル胃潰場二就テ報告シ, 其成因 7 胃網動脈 7 經由シ胃壁二到達スル動脈性血栓及門脈系統二發生スル静 脈血栓ノ逆行性栓塞ナリトシ，且，是等血栓、一部傳染性一部非傳染ナルコト ヨ主唱七y.氏一，再ビ實驗的二大網膜，結紮及捻轉 7 , 大黑鼠4匹及家鬼 1 頭 二就テ試ミタルニ, 前者二於テハ胃二何等變化 7 認メザリシモ, 後者二於テ多 發性粘膜出血 見タリト云フ。

（2）1900 年 Friedrich 氏八，其門下生 Hoffmann 氏卜共二，海猽26匹 匹用

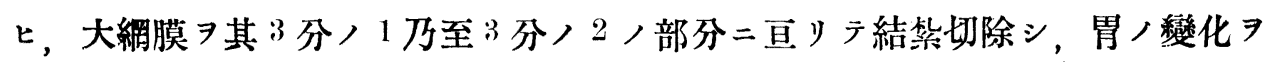
檢シタル二，其中 5 例二八大ナル胃潰場，4例二八粘膜出血， 2 例八充血，1例 八, ぺ先ニテ突キサシタル程ノ大サノ暗赤色ノ粘膜變化 ヨ認メタリト云フ. 兩氏八，亦，肝臟ノ梗塞 $モ$ 認メ，是等ノ戀化八，必ズシモ，傳染性血栓二由 ルヨ必要トセズト主張セリ。

（3）1901年 Enyelhard 及 Neck 兩氏八，海猽13匹，家鬼3頭，大 5 頭，合 計 21 例ノ動物二就キ，劍狀突起下二於 $33 \mathrm{~cm}$ 八縱切開二依リ,腹腔 7 開キ, 大網 膜 $\ni$ 引出シテ, 其小部分乃至大部分 7 結紮切除シ, 術後 3 日万至 12 日 7 經 其成績 $ᄏ$ 檢シタルニ, 5 例二於テ，點狀，胃粘膜出血, 11 例二於テ，大網膜結紮 部, 周图二血栓 7 認メタリ. 該血栓八稀二動脈中二存在スルモ, 主二靜脈中二 在リテ, 必ズ傳染性ノモノナリト云フ.氏等八, 海猽 6 匹, 家兔 3 頭, 犬 5 頭二 於テ, 大網膜 7 胃二近接シテ全部切除セルモE, 胃二何等潰場ノ形成ナカリシコ トヨ述心，且，該論文ノ終末二，家鬼 4 例ノ實驗記錄 7 揭ゲ，大網膜 7 胃二接 シテ全部結紫切除スルモ, 極メテホナル粘膜出血 $ヨ$ 見ルコトアルニ過ギザルョ, 特ニ高調セリ。

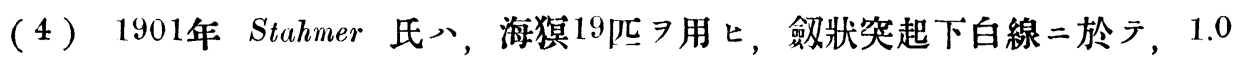
乃至 $2.0 \mathrm{~cm}$ ，緃切開 $习$ 施シテ, 腹腔 1 例二多發性胃潰瑝，2例二多發性胃潰暢及多發性粘膜出血， 4 例二粘膜出血, 3 例二胃潰場 7 形成シ，8例二於テ肝臟二梗塞 
ノ成因ニハ細菌ノ必要ナキコトラ主張セリ。

（5）1907年 Payr 氏八，海猽及家兔 7 用七，大網膜 7 凍冷或、灼熱 八其静脈二微粒體 7 泩入シ, 胃二默状, 粘膜出血乃至大豆大八潰掦 7 發生七シ

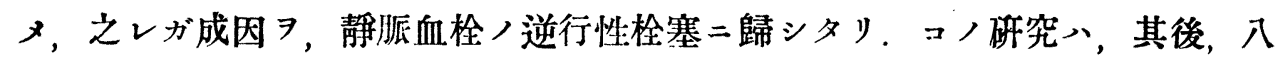
代氏二依り再試セラレ, 全ク根據無キモノナルコトヨ確メラレ, Х, 他/諸家 ノ研究ノ結果二據ルモ,コノ說二賛同スル學者無キガ如シ.

\section{以上ノ文献二對スル考按}

是等ノ文献、，胃潰瘍ノ實驗的研究者二反覆引用セラルル所ニシテ，其實驗 方法八，大網膜 $\ni$ 結紮，若ク八，切除スト記載七ラル、モ。果シテ大網膜ノ如 何ナル部分ヨ結督，若タハ，切除シタルャ明暸ナラズ. 其血管トノ關係，殊二 然リ。蓋シ, 腹腔 7 僅 $=1.0$ 乃至 $2.0 \mathrm{~cm}$ 開キテ, 該部ョリ㖘出セラル、大絹膜 ᄏ，胃二近接シテ全部切除スルガ如キハ, 余ノ經驗上, 殆, 不可能ノコトニシ テ, 强イテ大網膜 率引スル時、, 其軟弱ナル胃附著點二於テ, 離斷セラルル

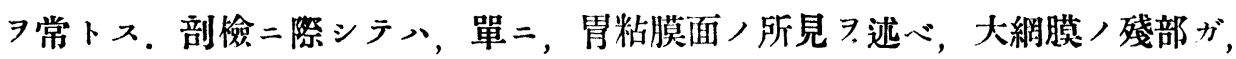
如何ナル癒著状態二在ルャ，或八，血管ト，關係ニアルヤ 注意スルコトナシ，

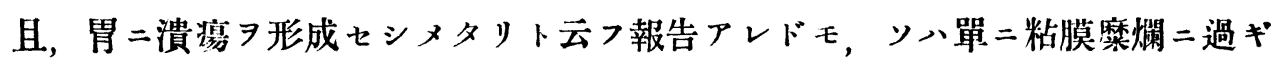
ザル程度ノ記載ナリ。

本章ニ於テハ，是等疑問，點 成七ル胃潰婸トノ成因的關係ノ有無 7 實驗セント欲フ。

\section{第 2 節 實驗}

\section{第 1 項 大網膜ア左右胃洞動静脈及胃二 近接シテ全切除セル實驗}

手術凖備八, 前章, 實驗卜同樣二之 $\exists$ 行七, 劒狀突起下白線二於テ, 約 $10 \mathrm{~cm}$,

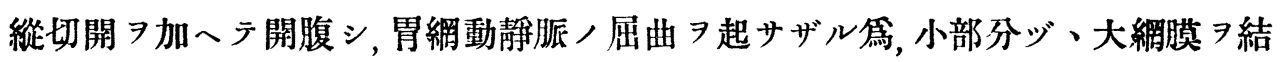
禁シ切除ス。剖檢二際シテハ, 大網膜,切除斷端部、肥厚卷縮シテ, 左右胃網動 静脈 包繞シ; 右胃網動静脈、上方二率退セラレテ胃大彎幽門部二瘉着スルモ, 其他二八特殊ノ異常ナシ. 胃粘膜二於ル變化 7 精查シ, 幽門部大彎ノ部八組織學 的二其變化／有無 7 檢索セリ. 個々八實驗例 7 ，1括シテ, 表示スレバ次ノ如シ. 


\begin{tabular}{|c|c|c|c|c|}
\hline 䝷驗家可 & 體 $(\mathrm{g})^{\text {重 }}$ & $\begin{array}{l}\text { 生 存 } \\
\text { 期 間 }\end{array}$ & 胃粘 膜面 ノ變化 & 幽門部大維組糡學的變化 \\
\hline 34號 & $-2150-1890$ & 2 日 & $\begin{array}{l}\text { 胃體〉棞壁二牛米粘大ノ粘膜 } \\
\end{array}$ & 異常ナシ. \\
\hline 35號 & $2160-1970$ & 3 日 & 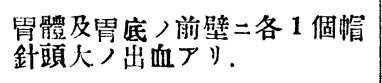 & $\begin{array}{l}\text { 粘膜下組織稍肥厚シ血管充盈. } \\
\text { 入. }\end{array}$ \\
\hline 36 號 & $2300-1950$ & 4 日 & $\begin{array}{l}\text { 畕體/前譬及後壁二各 } 1 \text { 個牛 } \\
\text { 米粒。。 }\end{array}$ & 異常ナシ. \\
\hline 37號 & $1840-1700$ & 6 日 & 異狀ナシ. & $"$ \\
\hline 38 號 & $1900-1740$ & 8 日 & 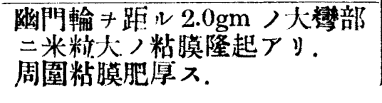 & 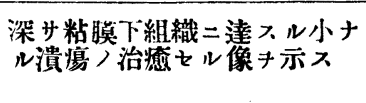 \\
\hline
\end{tabular}

\section{第 2 項 大湔膜ノ 1 部分 7 切除七ル實驗}

欱状突起下白線二於テ, 約 $3 \mathrm{~cm}$ ，縱切開 7 加一 シテ，左右胃網動靜脈，中間二於テ，其 5 分，1 万至 3 分， 1 ノ部 7 結紮切 除入.

剖檢二際シテハ，大網膜ノ斨端入肥厚シテ，腹壁創，若クハ，腸管ト癒着ス ルモノ多シ。胃粘膜ノ變化 $\ni$ 精查シ，幽門部大彎ノ部 7 組織學的二檢查ス。個 トノ實驗例 7,1 括シテ，表示スレバ次ノ如シ.

\begin{tabular}{|c|c|c|c|c|}
\hline 實驗家鬼 & 㵦 $(g)^{\text {重 }}$ & 生 存 & 胃 粘 膜 面 變 化 & 胸門部大䌅組織學的變化 \\
\hline 39 號 合 & $1950-1760$ & 2 日 & 異常ナシ. & 異常ナシ. \\
\hline 40 號 & $2200-1870$ & 4 日 & 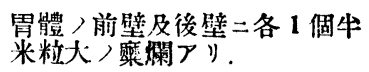 & $n$ \\
\hline 41 號 $\delta$ & $2130-1820$ & 6 日 & 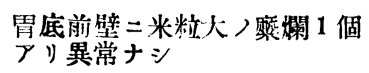 & $"$ \\
\hline 42躆 & $2050-1790$ & 8 日 & 異常ナシ. & $" 1$ \\
\hline 43號 ㅇ & 19801810 & 10日 & $" \prime$ & $" 1$ \\
\hline
\end{tabular}

\section{第 3 篩 實駿成績ノ總括及考按}

大網膜 $\exists$ 全部切除セルモノ 5 例ノ中 $=3$ 例 (34號，35號，36號），大網膜ノ1 部分 $\exists$ 切除七ルモ，5例／中 2 例 $(40$ 號, 41 號 $)=$ 於テ 、, 其胃二, 粘膜出血乃\} 


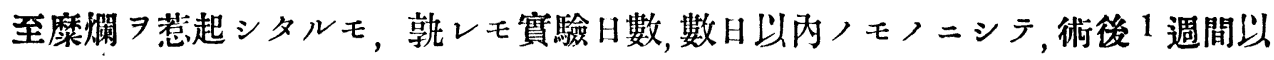
上 $\ni$ 經タル實驗例ニメ, 總テ其胃二變化 7 認ムル事ナシ. 蓋シ, 大網膜ノ切除二 ヨリテ, 動物, 胃二, 粘膜出血乃至糜爛 7 起 事アルモ, 之等八, 總テ早期二治癒 スルモノニシテ，交獻，語ルガ如ク，胃潰韵ヨ惹起スル事アルガ如キハ，余，

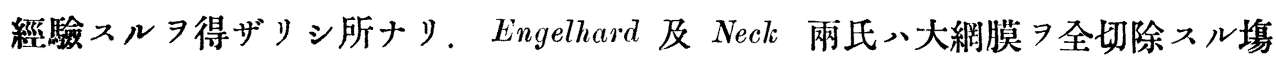
合ニ八，胃二變化ナキモ，其 1 部分 $\ni$ 切除スル特八，胃二出血糜爛乃至潰语 惹起スト云フモ, 余ノ實驗例二於テン, 胃二粘膜出血乃至糜爛 八, 大網膜ノ 1 部分及全部 7 切除スル鹪合二於テ, 格別/差違アルタ認メズ. 反之, 大網膜 $コ$ 全切除七ルモノニ於テン，左右胃網動静脈ガ大網膜，肥厚セル

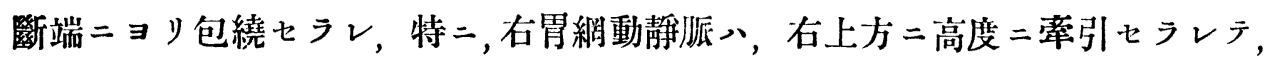
胃幽門部二密著シ, 其屈曲 $=ョ$ リ, 可成高度ノ血行障礙 7 , 胃二惹起シ得ル モノニシテ，實驗動物第33號二於テハ，第 1 章二於ケル實驗動物ト同一，部位

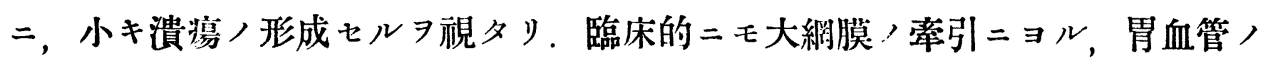

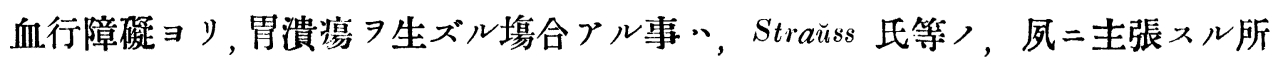
ニシテ, Mandl氏、, 上腹部へるにあ患者 40 例 7 , 手術シタル二, 內 15 例二,

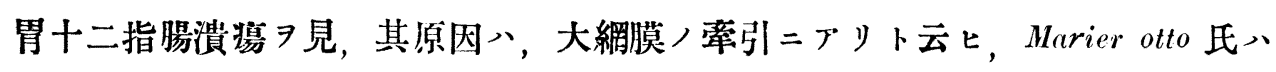
大網膜二脂肪組織,多量二著着セルガ第二, 胃症状 7 呈シタル患者 5 例 7 手術

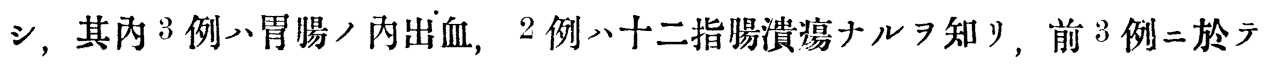
八, 大網膜, 1 部 7 切除シテ其率引 7 去りタル二,術後胃症狀消退セリト云フ。 佾, 交獻二據レバ, 大網膜ノ切除入, 屡々, 肝贜二梗塞或入壞死 $\ni$ 伴フモ八、如 クナルモ，余ノ本章二於ル實驗例ニン, 1 例モ斯ル變化 7 認メ得タルモノナシ. 前記第 1 章, 實驗例中, 2 例（第 4 號，第 14 號）二於テ,肝小葉，周邊部二, 境

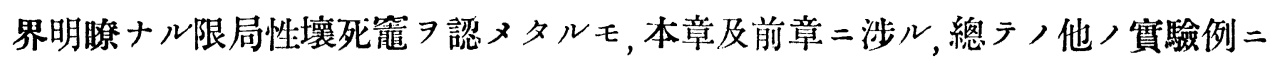

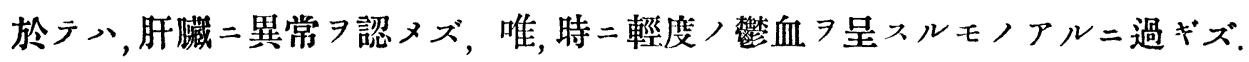

\section{第 3 章 胃大彎二於テ幽門䄖ヨリ左胃網 動靜脈ニ至ル總テノ血管ヨ結督 或八結惄切斷セル實騇}

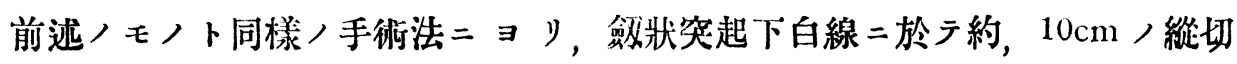


小俣武椺

(153)

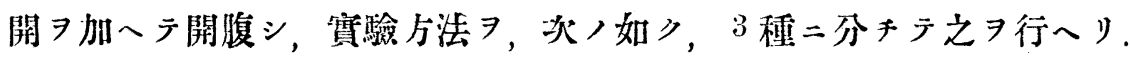

(A) 該部血管 $\ni$ ，胃大彎二近接セル部位二於テ，可及的個々二結紫ス.

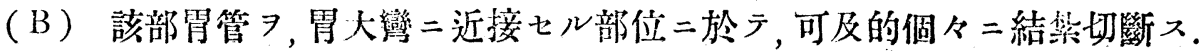

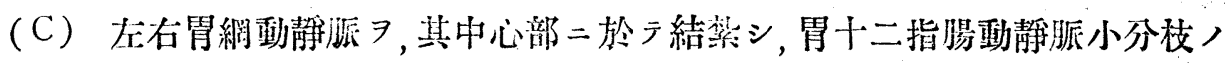
幽門ニ入ルモノヨモ，可及的中心部二於テ結箱ス。

個々ノ筫羷刭 $7 ， 1$ 括シテ，表示スレバ炏ノ如シ。

\begin{tabular}{|c|c|c|c|c|c|c|}
\hline 䝿驗家鬼 & 賽驗 & 體 $(\mathrm{g})^{\text {重 }}$ & 告者 & 瀆煌發生部位 & 潰湢 つ性 狀 & 備 \\
\hline 44俿 & A & $1940-1590$ & 6 日 & 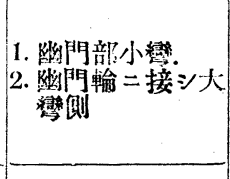 & 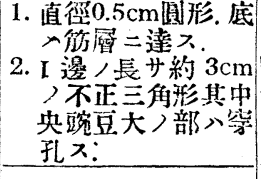 & $\begin{array}{l}\text { 盟粘膜ノ他部二異 } \\
\text { 常ナシ. }\end{array}$ \\
\hline 45 號 & A & $2000-1770$ & 14日 & 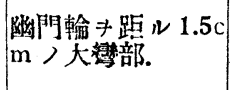 & 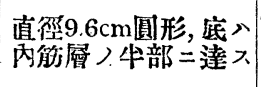 & 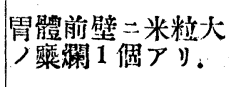 \\
\hline 46淲 & A & $1950-1780$ & 30 日 & " & 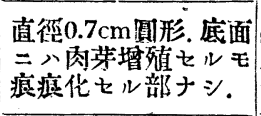 & $\begin{array}{l}\text { 霄粘膜〉他部二異 } \\
\text { 常ナシ。. }\end{array}$ \\
\hline 47號 & B & $2030-1630$ & 5 日 & 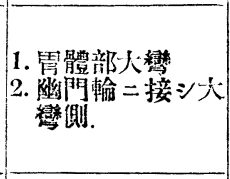 & 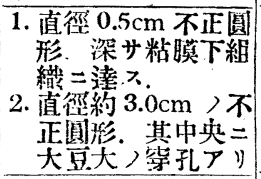 & 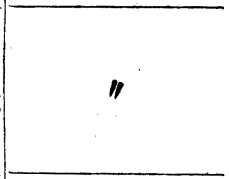 \\
\hline 48號 & B & $2190-1620$ & 7 日 & 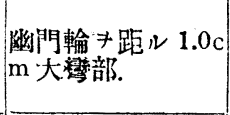 & 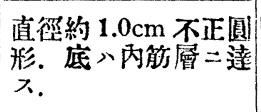 & 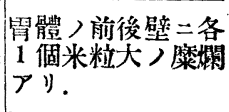 \\
\hline 49號 & B & $2150-1370$ & 10日 & 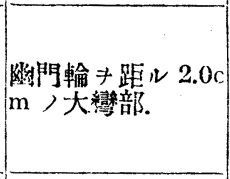 & 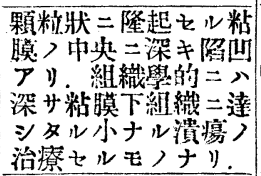 & 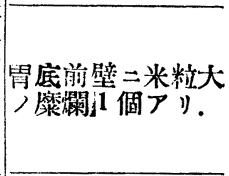 \\
\hline 50號 & C & $2300-1750$ & 6 日 & 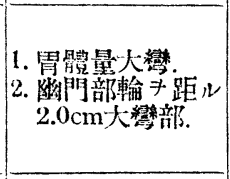 & 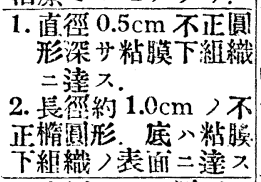 & $\begin{array}{l}\text { 胃粘膜/他部二異 } \\
\text { 常ナシ. }\end{array}$ \\
\hline 51 號 & C & $2130-1680$ & 10日 & 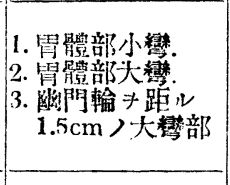 & 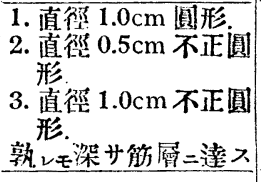 & 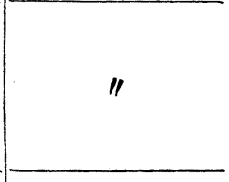 \\
\hline 52號 & C & $1980-1510$ & 21日 & 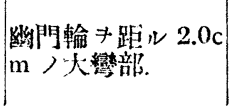 & 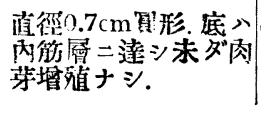 & $\begin{array}{l}\text { 留體入前壁二點狀 } \\
\text { フ出血數個アリ。 }\end{array}$ \\
\hline
\end{tabular}




\section{實驗成績ノ總括及考按}

以上ノ實驗例ノ總テニ於テ，第 1 章ノ各實驗例卜，略同一ノ部位二潰凗 7 形

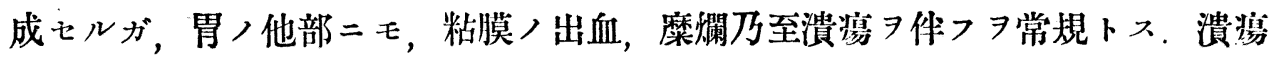
八數ハ, 1 個乃至 3 個, 其大サハ, 實驗動物第44號及第47號二見ルガ如ク，殆，全 幽門部 占メ, 且, 遂二第孔 7 來セルモノョリ，實驗動物第 49 號二於ルガ如ク，

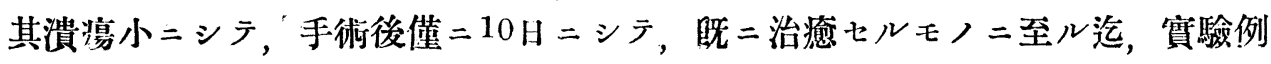
ニョリテ甚シク，相違セリ．サレド，概シテ第 1 章ノ實驗二由ル潰演二比スレ

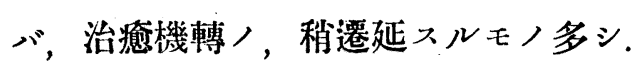

剖檢所見二據レバ，血行ノ障礙二陷レル大網膜入，甚シク肥厚卷縮シテ，殆 常二, 胃大彎二密着シ, 或入, 腸管肝欌若入腹壁創卜癒着ス。惟フ二, 大絧膜,

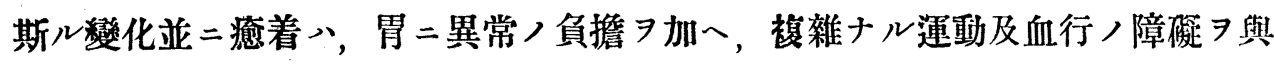

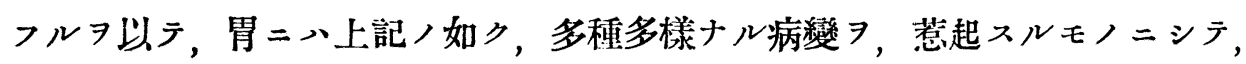

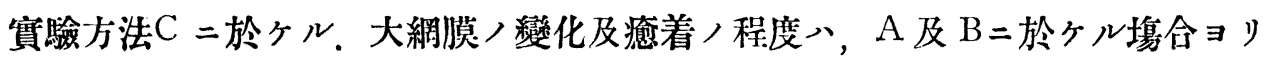
モ，更二，顯著トナリ，從テ，胃二於ヶル變化モ，之ト一致シテ，一層袙㒕 加フ. 之 7 更二, 第 1 章ノ實驗ニ比スレバ，其成績ニ著シキ差異アリテ, 到底 定型的ナル胃潰演ノ形成ハ期待シ難シ.

\section{第 4 童 大应膜古半及胃十二指腸動靜胍 小分枝ノ幽門二至ル部分 尹血管 ト共二組織 尹全切除ス}

手術法八，前述ノモノト同樣ニシテ，劒狀突起下白線ニ於 $\bar{\gamma}$, 約 $1.0 \mathrm{~cm}$ 八縱 切開 $コ$ 加へラ開腹シ，大網膜八可及的殘部 $コ$ 毁損セザル樣小部分ジ、結紧切斷 セリ.

個々ノ實驗例 ア，1 括シテ，表示スレバ次ノ如シ. 


\begin{tabular}{|c|c|c|c|c|c|}
\hline 筫驗家牙 & 體 $(g)^{\text {重 }}$ & $\begin{array}{ll}\text { 生 } & \text { 存 } \\
\text { 期 } & \text { 間 }\end{array}$ & 㵋煌發生部位 & 潰 榎 つ性: 状 & 俑 \\
\hline 53 號 & $1920-1730$ & $3 \cdot$ 日 & 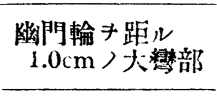 & $\begin{array}{l}\text { 直德 } 0.5 \mathrm{~cm} \text { 圓形. 底八粘 } \\
\text { 㴔組入. }\end{array}$ & 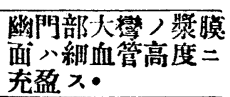 \\
\hline 54號 & $2120-1790$ & 4 日 & 無 & & 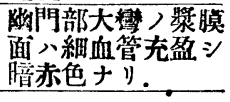 \\
\hline 55號 & $1980-1400$ & 5 日 & 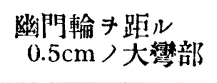 & 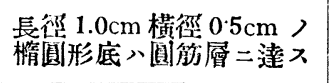 & "I \\
\hline 56 號 & $1970-1530$ & 6 日 & 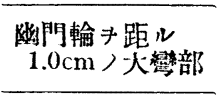 & 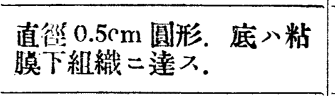 & 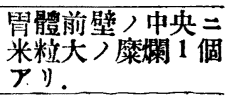 \\
\hline 57 號 & $2090--1560$ & 7 日 & 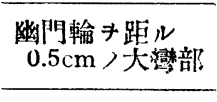 & 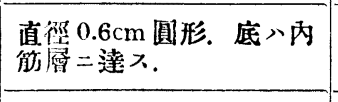 & 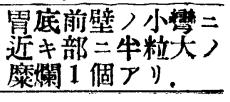 \\
\hline 58號 & $2070-1880$ & 8 日 & 無 & & \\
\hline 59號 & $1960-1700$ & 10日 & $\begin{array}{l}\text { 幽門翰 キ距ル } \\
1.0 \mathrm{~cm} \text { 䇣部 }\end{array}$ & 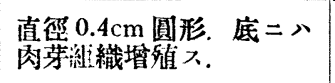 & \\
\hline 6C號 & $19=0-1750$ & 14日 & $\begin{array}{l}\text { 幽門輪斗距, } \\
0.5 \mathrm{~cm}\end{array}$ & 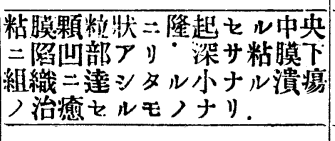 & \\
\hline 61號 & $2260-1860$ & 15日 & 無 & & \\
\hline 62號 & $2150-1770$ & 21日 & $\begin{array}{l}\text { 幽門輪于距儿 } \\
0.8 \mathrm{~cm} \text { 大彎部 }\end{array}$ & 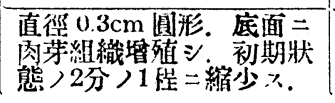 & \\
\hline
\end{tabular}

\section{實験成䥊ノ總括及考按}

實驗動物 10 例中， 7 例二於テ; 幽門輸 $\exists$ 距 $ル 0.5$ 乃至 $1.0 \mathrm{~cm}$ 八大彎部二潰場

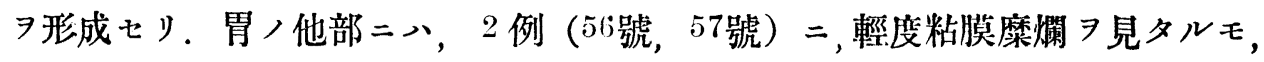

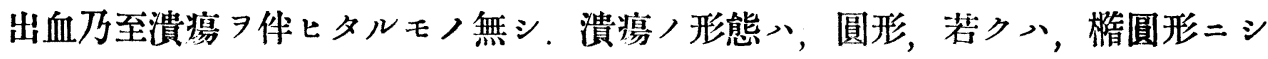

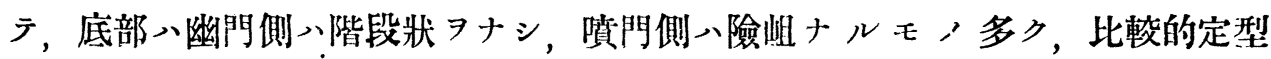
的ナルモ，總ラ同一形態乃至科度ノモノ 7 得ルコトハ，之 期待シ難ク，一般 二第 1 章, 賽驗ニ由ル潰場二比スレバ輕度ニシラ，其治癒機轉モ稍迅速ナリ。 手術後, 幽門部大彎, 漿膜面八細血管, 充盈 $コ$ 來セルモ，第 1 章ノ實驗動物卜 同樣二, 約 5 日

剖檢ニ據レバ，大網膜左牛ノ切除緣ハ僅二肥厚スルヒ, 殆, 卷縮シ,若クハ,

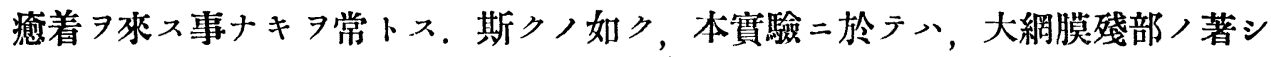
キ變化癒著 
(156)

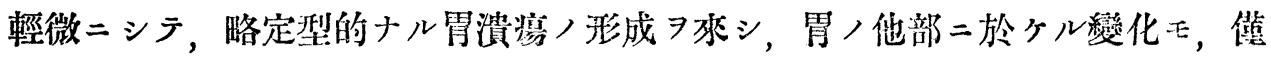

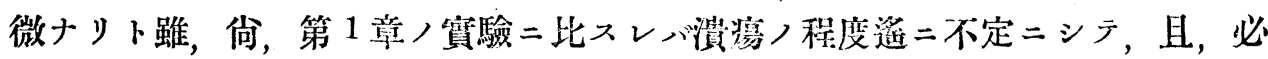
發的二，總テノ賽羷例二其發生 7 期待スル事

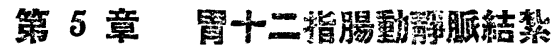

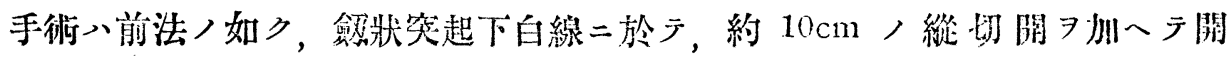

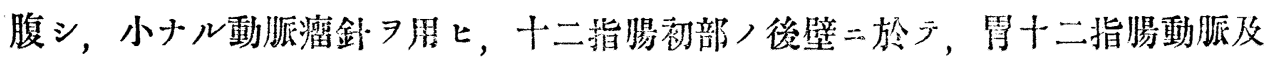
静胍 $\ni$ 同㭙二結紮七り。

個々ノ實驗例 $7 ， 1$ 括シテ，表示スレバ次ノ如シ.

\begin{tabular}{|c|c|c|c|c|c|c|}
\hline 箕驗家 & & 體 $(g)^{\text {重 }}$ & $\begin{array}{l}\text { 生 在 } \\
\text { 期 間 }\end{array}$ & 溃㛫發生部位 & 溃 滰 つ 性 狀 & 䚚 \\
\hline 63號 & $\hat{o}$ & $2150-1950$ & 1 日 & 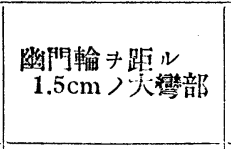 & 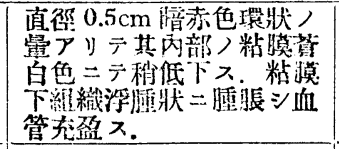 & $\begin{array}{l}\text { 十二指腸䡬度二浮 } \\
\text { 朠キ呈ス. }\end{array}$ \\
\hline 64 號 & $\hat{o}$ & $2120-1660$ & 3 日 & 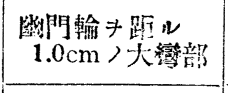 & 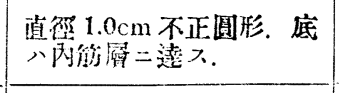 & 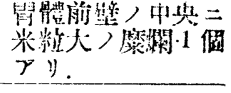 \\
\hline 65號 & $\hat{o}$ & $1900-1430$ & 3 日 & $" \prime$ & 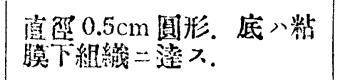 & \\
\hline 66號 & $\hat{o}$ & $1760-1570$ & 4 日 & $" \prime$ & 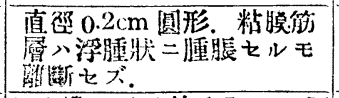 & 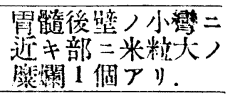 \\
\hline 67號 & $\hat{o}$ & $2000-1420$ & 4 日 & 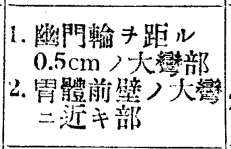 & 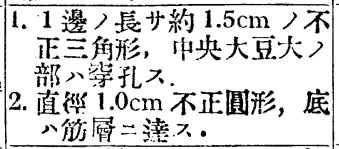 & $\begin{array}{l}\text { 上二指腸初部 } 2.0 \mathrm{c} \\
\mathrm{m} \text { 部浮腄狀二膨淽 } \\
\text { 入. }\end{array}$ \\
\hline 68號 & $\hat{o}$ & $2100-1610$ & 4 日 & 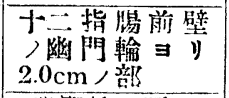 & 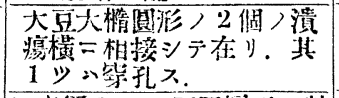 & 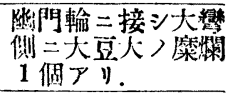 \\
\hline 69號 & 우 & $2050-1540$ & 7 日 & 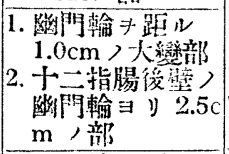 & 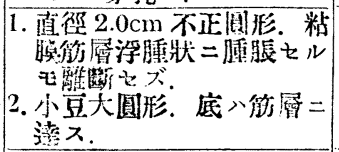 & 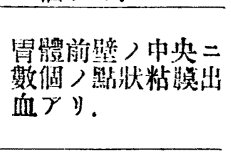 \\
\hline 70號 & 우 & $1950-1290$ & 7 日 & 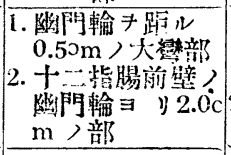 & 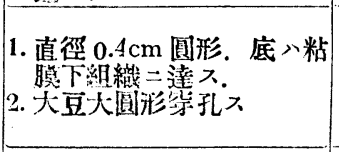 & 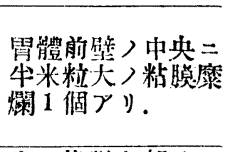 \\
\hline 71 躆 & $\hat{o}$ & $1680--1340$ & 8 日 & 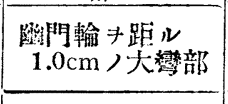 & 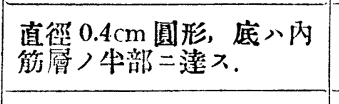 & 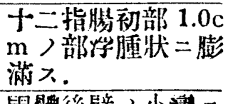 \\
\hline 72號 & 우 & $2060-1580$ & 10 日 & $\|$ & $\begin{array}{l}\text { 直潩 } 0.5 \mathrm{~cm} \text { 不正圆形. 底 } \\
\text { 八倣層二達入. }\end{array}$ & 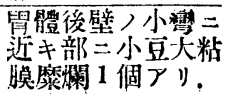 \\
\hline
\end{tabular}




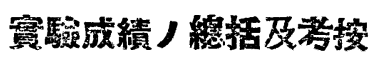

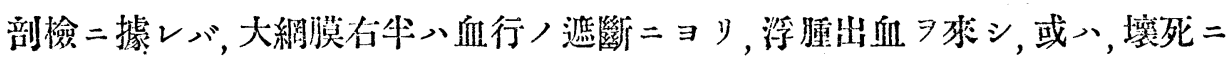

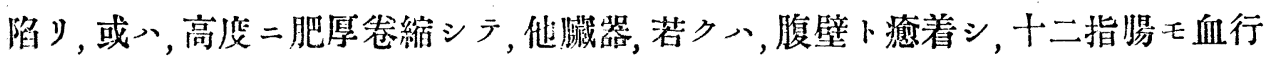

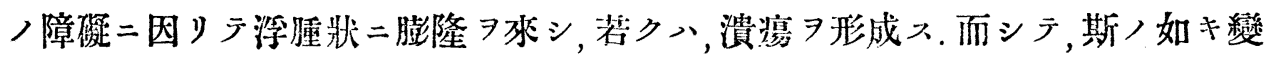

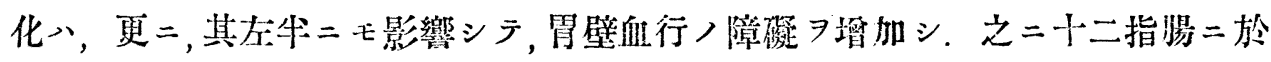
ル障礙モ加ハルガ故二, 前記諸章ノ敦レノ實驗ニ比スルモ,實驗動物ノ祽弱最モ

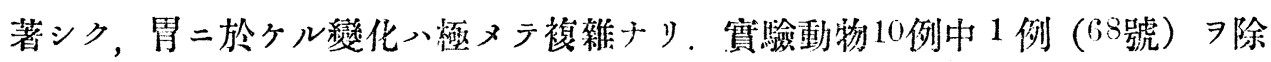

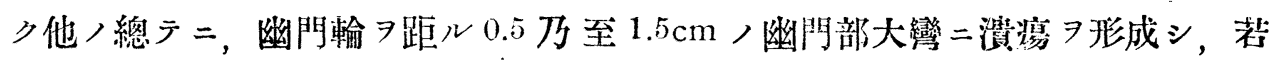

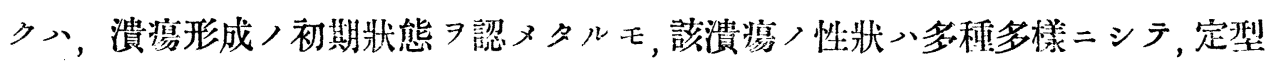
的ノ構造 アナスモノ八，殆無ク，其大少モ，實驗動物 97 號二於ヶルガ如ク，殆全

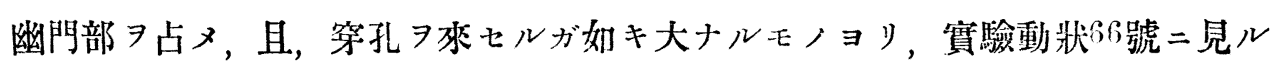
ガ如ク, 極メラホニシラ, 進行, 度輕微ナルモノニ至ル迄, 個タ/實驗例二ヨ リ甚シキ相違アリ。十二指腸二、3 例 $(68$ 號，69號，70號）二於方淇場/形成

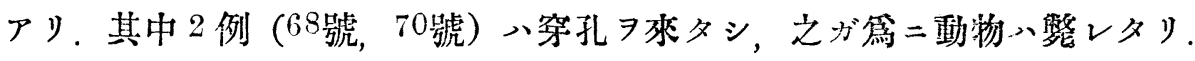

嘗う，後藤七郎氏及近森正基氏ニヨリ發表セラレタル賽驗，即，家鬼，左胃

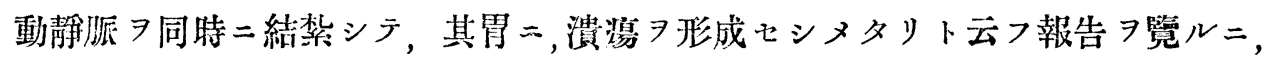
敦レモ湍演ノ性狀及發生部位ノ一定ナラザリシト云フ記載アリ。惟フニ，小彎 側二於ル血管ノ結紫》，殊二，家兔二於テン，該部狄隘ナルガ第二，其操作二

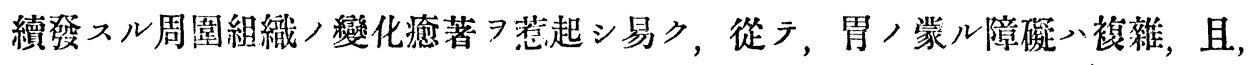
高度ナルキ以テ，雨氏ノ經驗セルガ如キ，實驗成績二到達スルモノナラン．余

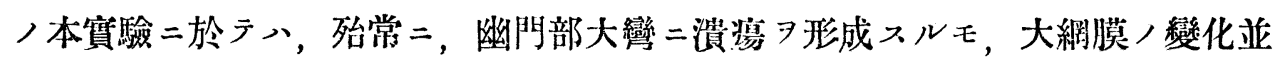
二癒着二伴フ影響ニョリ，其彩態性状一定ナラズ，且，胃，他部二モ，粘膜，

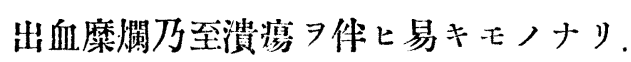

\section{第 6 章 留十二指腸動胍結督}

前章二述心゙ル，胃十二指晹動脈及靜脈，同特結督卜，同一／部位二於テ，今

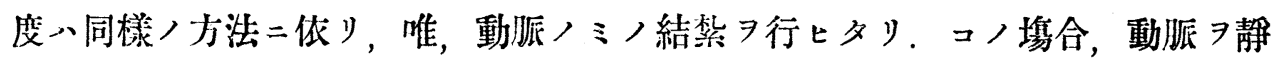
脈ヨリ分離シテ單獨二結督スルハ, 比較的困難ニシテ，ヤ、モスレバ，靜脈

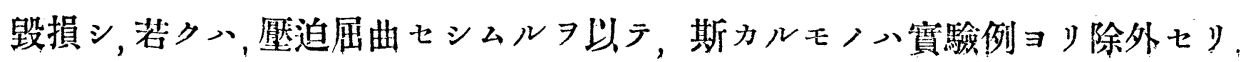


個々ノ實驗例 7,1 括シテ , 表示スレバ次ノ如シ.

\begin{tabular}{|c|c|c|c|c|c|c|}
\hline 賽驗家 & & 體 $(\mathrm{g})^{\text {重 }}$ & $\begin{array}{l}\text { 告 } \\
\text { 期 間 }\end{array}$ & 潰韵潑生部位 & 溃 瘍 ノ 性 狀 & 備 \\
\hline 73號 & $\hat{o}$ & $2200-2000$ & 1 日 & $\begin{array}{l}\text { 幽門輸 キ距， } \\
1.0 \mathrm{~cm} \text { ノ彎部 }\end{array}$ & 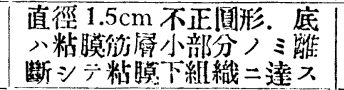 & 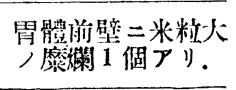 \\
\hline 74號 & $\hat{o}$ & $2240-1950$ & 2 日 & $\begin{array}{l}\text { 十二指腸中央 } \\
\text { 前壁 }\end{array}$ & 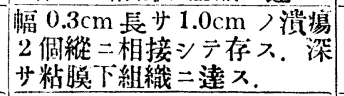 & \\
\hline 75號 & 우 & $2140-2010$ & 5 日 & 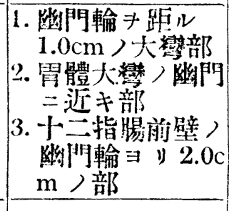 & 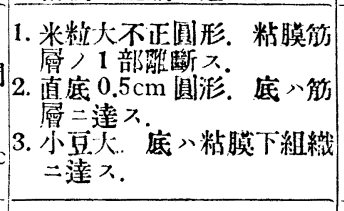 & \\
\hline 76號 & $\hat{o}$ & $2380-2090$ & 6 日 & 無 & & \\
\hline 77號 & 우 & $1030-1270$ & 6 日 & 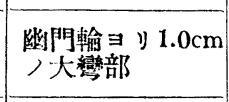 & 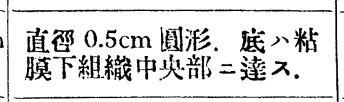 & 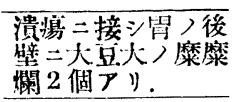 \\
\hline 汭淈 & 우 & $1970-1360$ & 7 日 & " & 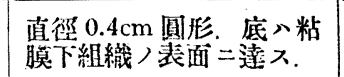 & 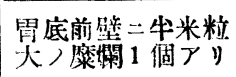 \\
\hline 79號 & $\hat{\delta}$ & $2180--1670$ & 7 日 & 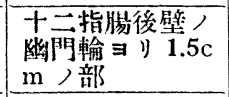 & 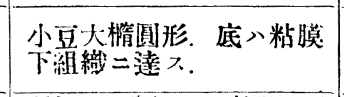 & \\
\hline 80 號 & $\hat{o}$ & $2050-1750$ & 10日 & $\begin{array}{c}\text { 幽阿輪 キ距ル } \\
1.5 \mathrm{~cm} \text { ノ大彎部 }\end{array}$ & 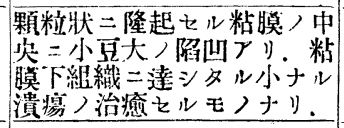 & 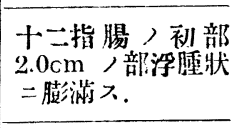 \\
\hline 81號 & ㅇ & $2230-1920$ & 10日 & 無 & & \\
\hline 82 號 & ㅇ & $2180-1760$ & 14日 & 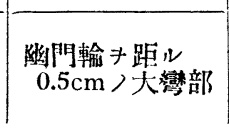 & 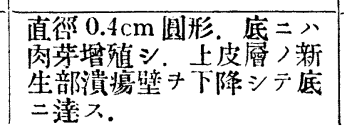 & \\
\hline
\end{tabular}

實驗成綪 ノ總括及考按

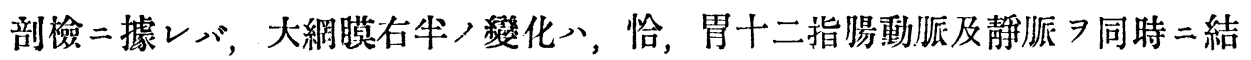

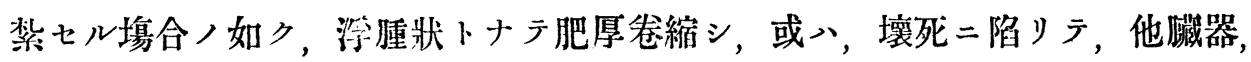
若ク八，腹壁ト癒着スルモ，其程度概シラ稍輕度ナリ。胃二於ケル所見ノ複椊

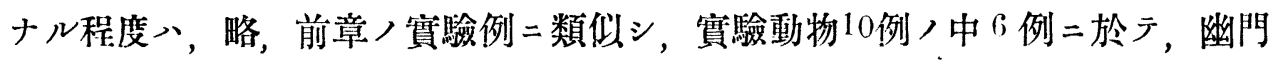

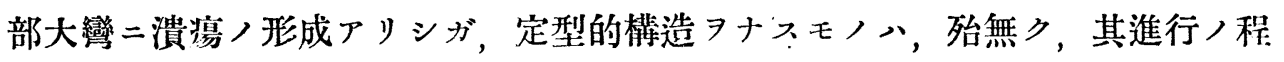

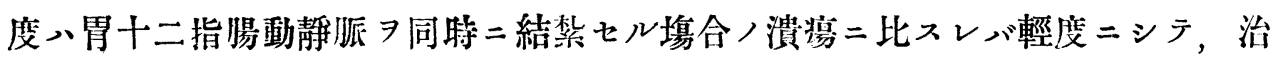
癒機轉モ稍迅速ナリ。十指腸二ハ3例 $(74$ 號，75號，79號）二潰演ノ形成 7 見タルガ，前章，實驗ニ於ルガ如ク，第孔 $习$ 來シタルモノナシ.

既記，近森正基氏八，左胃動静脈 $习$ 同洔二，若クハ，個タ二結紮七ル實驗， 
小

俣

武

述

(159)

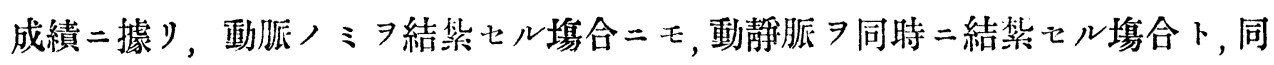
一程度ノ潰焬 $ᄏ$ 同一八割合二形成スト主張スルモ，余入，本實驗ノ結果二基キ,

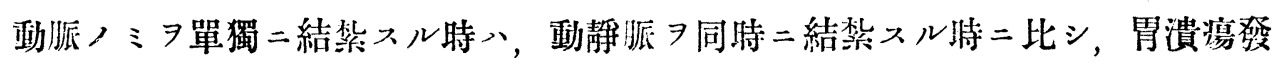
生ノ頻度及程度, 遥二輕少ニシテ, 其治癒機轉モ一層迅速ナリト信ズルニ至レ リ。蓋シ，狄险ナル胃ノ小彎侧二比スレバ，大彎侧入實驗的操作容易ニシテ，

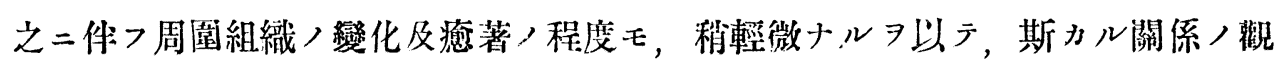
察二八, 正鴊习得易キモノナラン.

\section{第 7 章 胃十二指腸靜脈結䋈}

前章二於テ，動眽 結紫七ルト同一ノ部位ニテ，同方法ニョリ，静挀ノミア

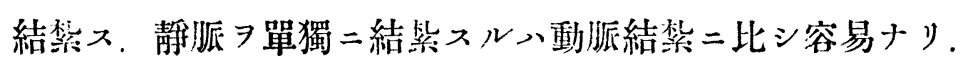

個ふノ實驗例, 1 括シデ，表示フレバ次ノ如シ.

\begin{tabular}{|c|c|c|c|c|}
\hline 貫驗冢可 & 體 $(g)^{\text {重 }}$ & $\begin{array}{l}\text { 告 襇 } \\
\text { 期 }\end{array}$ & 溃塄發生 & 備 \\
\hline 83號 † & $2290-2100$ & 2 日 & 無 & \\
\hline 84號 & $1900-1650$ & 3 日 & $" \prime$ & \\
\hline 85號 & $1930-1850$ & 4 日 & $"$ & \\
\hline 86號 & I $960-1840$ & 5 日 & $n$ & 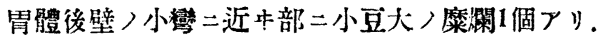 \\
\hline 87號 & $1850-1800$ & 6 日 & $" 1$ & \\
\hline 88號 & $1830-1780$ & 6 日 & " & \\
\hline 89 號 & $2130-2090$ & 7 日 & $" \prime$ & 胃底前壁ノ中央二米䊀大ノ糜闌1個アリ。 \\
\hline 90號 & $1980-1910$ & 8 日 & " & \\
\hline
\end{tabular}

\section{實驗式綪ノ總括及考按}

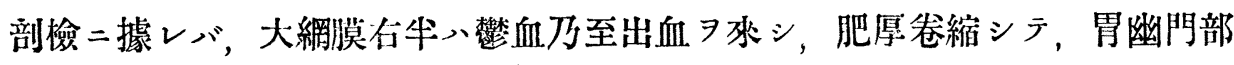

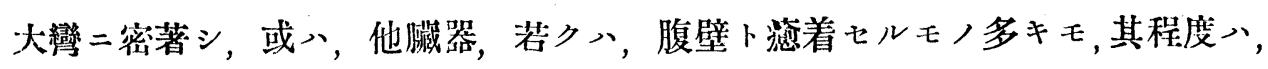

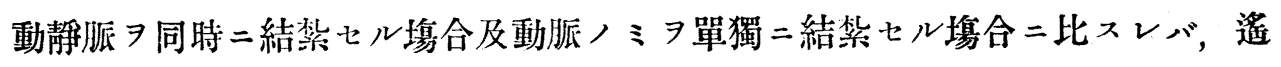


(160)

二輕度ナリ。胃及十二指腸二八著變ナク，實驗動物 8 例中 2 例（89.號，89號）

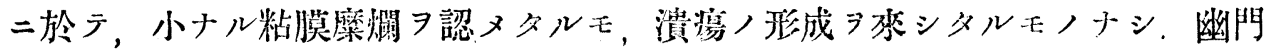

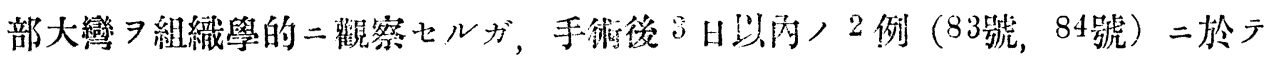

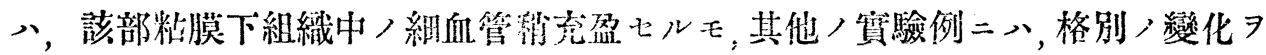
認メタルモノナシ，十二指腸二モ濽婸习形成スルコトナシ.

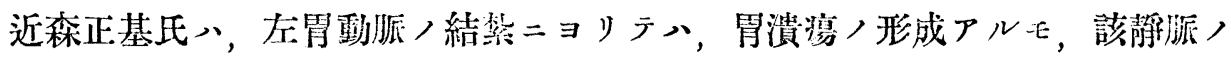

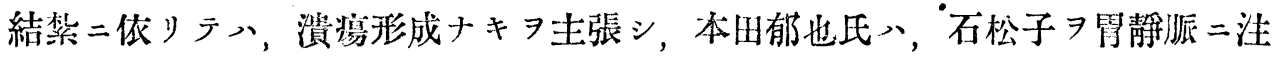

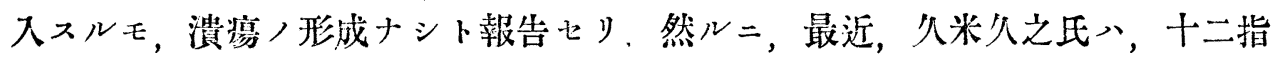

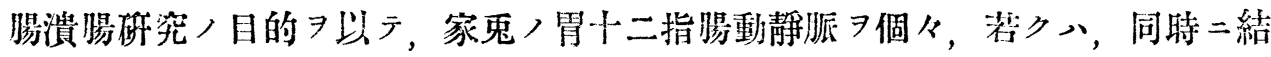

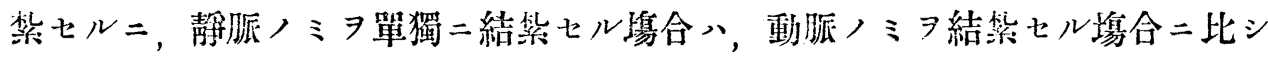

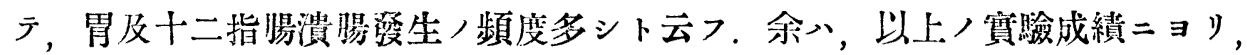

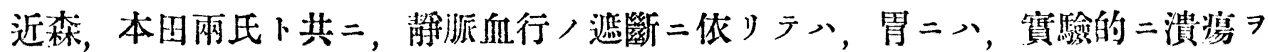
硲生セシムルコトヨ得ザルモノナリト信ズ.

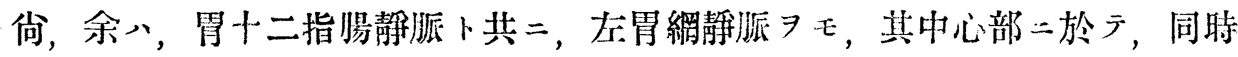

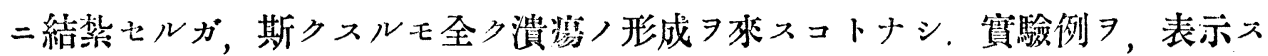
レバ, 头ノ如シ.

\begin{tabular}{|c|c|c|c|c|}
\hline 顀驗家鬼 & 體 $(\mathrm{g})^{\text {重 }}$ & 生 青 & 溃湯發生 & 偖 \\
\hline 91號 & $2350-2180$ & 2 日 & 無 & \\
\hline 92號 & $1690-1930$ & 3 日 & $"$ & 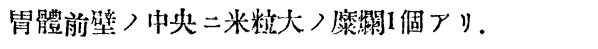 \\
\hline 93號 & $2080-1990$ & 4 日 & " & 胃體前壁ノ大彎二近キ部二大豆大ノ䈋闌（個アリ。 \\
\hline 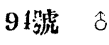 & $1860-1830$ & 5 日 & " & \\
\hline
\end{tabular}

\section{第 8 章 腸管ノ癒莱シヨル胃壁剽血行新}

生ノ胃潰湯發生三及ホス影響

前法ノ如ク處置シ，開腹シテ，先ヅ, 第 1 章ニ於テ記述セル如キ手術 之二, 更二, 次八如キ手術 7 加 7 . 
（A）十二指腸初部前壁，腸間膜附著點 $=$ 近キ部分 $刃$, 數個所ノ縫合 長少約 $5.0 \mathrm{~cm}$ ，幽門部大彎二癒著七シム。

（B）胃十二指腸動静脈 $习$ 結禁シ，（A）>如ク處置入。

個々ノ實驗例 7 , 表示スレバ, 次ノ如シ

\begin{tabular}{|c|c|c|c|c|c|c|c|}
\hline 賽驗家牙 & & $\begin{array}{l}\text { 賽驗 } \\
\text { 方法 }\end{array}$ & ${ }^{\text {體 }}(\mathrm{g})^{\text {重 }}$ & 生 & 潰煬發生部位 & 潰煬ノ性狀 & 備 \\
\hline 9:號 & $\hat{o}$ & A & $1900--1630$ & 6 日 & 無 & & 淕著極メテ良好 \\
\hline 96淲 & $\hat{\delta}$ & A & $1910-1790$ & 6 日 & $" \prime$ & & " \\
\hline 97號 & q & $\mathbf{A}$ & $2200-1940$ & 7 日 & $\begin{array}{l}\text { 胸門輪 } 7 \text { 距 } \\
1.0 \mathrm{~cm} \text { 彎部 }\end{array}$ & 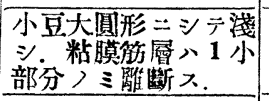 & $"$ \\
\hline 98號 & $\hat{\delta}$ & A & $1980-1690$ & 7 日 & 無 & & " \\
\hline 99號 & $\hat{o}$ & $\mathbf{A}$ & $1890-1630$ & 7 旦 & $\begin{array}{l}\text { 物門輪 キ距ル } \\
1.0 \mathrm{~cm} / \text { 大彎部 }\end{array}$ & 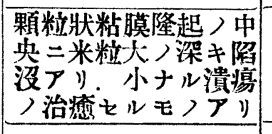 & $" \prime$ \\
\hline 100號 & P & $\mathbf{A}$ & $2130-1920$ & 78 & 無 & & $"$ \\
\hline 101號 & $\hat{\delta}$ & $\mathbf{A}$ & $1950-1590$ & 5 日 & 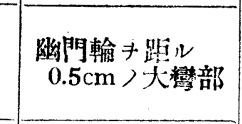 & 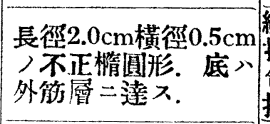 & 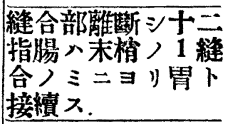 \\
\hline 102號 & 우 & $\mathbf{A}$ & $2100-1750$ & 5 日 & 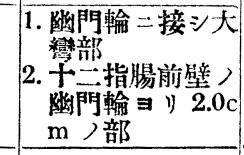 & 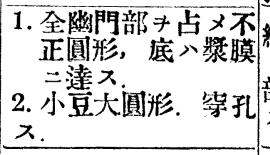 & 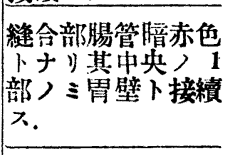 \\
\hline 103號 & $\hat{o}$ & B & $2240-1800$ & 3 日 & 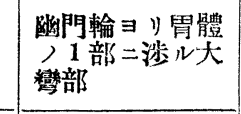 & 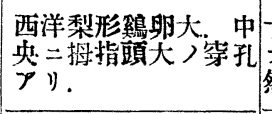 & $\begin{array}{l}\text { 十二指䐇腤赤色下 } \\
\text { ナり澺著不良. 自 } \\
\text { 然庞. }\end{array}$ \\
\hline 104號 & 早 & 13 & $1980-1610$ & 4 日 & 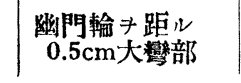 & 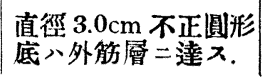 & $" \prime$ \\
\hline
\end{tabular}

\section{嘪驗成績ノ總括及考按}

胃腸兩壁, 癒着良好ナルモノニ於テハ, 肉眼的二モ兩者血行ノ連絡 7 認メ, 之 $\exists$ 組織學的二檢スルニ，兩浆膜面八直接相密著シ，或八，其間二堆殖セル肉 芽組織 7 認么

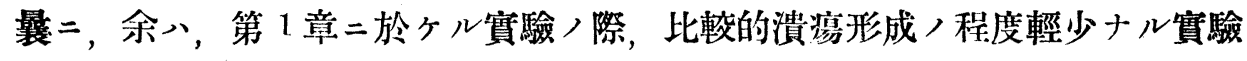
動物 2 例 7 得タルガ，其兩者共二，腸管ノ一部分ガ幽門部大彎二瘉着セルタ認 
(162)

メ, 該 2 例八第 1 章ノ實驗例 $\exists リ$ 除外セリ。之レ, 腸管/癒著ニ伴フ, 副血行

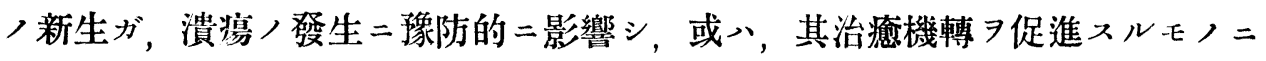
非ズャト思惟セル故ナリ。而シテ，斯カル想定ノ下二，茲二，本實驗 ルガ, 果シテ, 豫期ノ如ク, 潰湯ノ發生 7 , 略, 完全二豫防シ, 又, 縱令, 潰 勭ノ形成アルモ, 極メテ輕微ニシテ, 且, 治癒機轉ノ速ナル事實 7 認メタリ. 反之，上表ノ示スガ如ク，縫合後／癒着不良二終レル場合，及ビ,.十二指腸， 縫合二際シ，胃十二指腸動静脈 結紮シテ，其壁ノ血行障礙 特八, 潰場ハ速二進行シ，甚シキハ幽門部全面壞死二陷ルニ至ル。

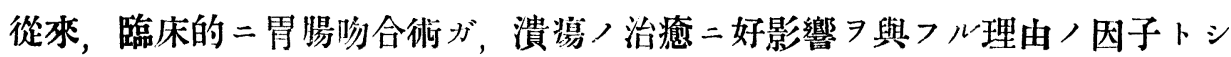

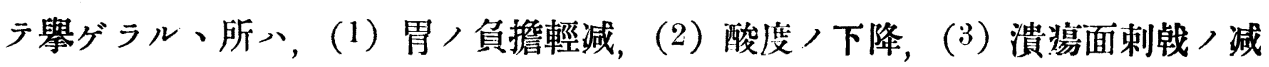

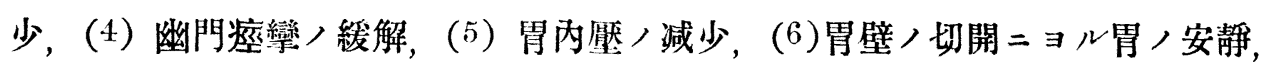
等ナリ。動物實驗ノ結果 , 直チ二, 人類二適用スベカラズト雖, 余八, 本實

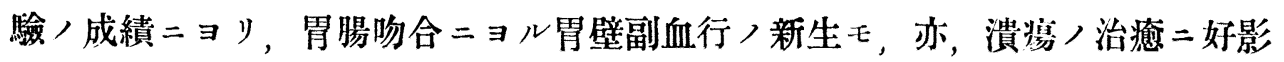
響ヨ與フルー因子トナリ得可シト思惟ス。

\section{第 9 章 本編ノ總括及考按}

本編各章二記述セル諸實騟，成積 7 綜合シ，之二，總括的粯察並二考按 7 試 ムルント次ノ奶シ。

（1）胃潰場形成，實驗方法.

余ハ，第 1 音二揭グタルガ如ク，自ラ考案セル比較的簡單ナル手術的操作二 ヨリ，家鬼，胃大彎壁二接シテ，大網膜 7 其血管卜共二切除シ，依テ，胃，一 定部位二, 略, 定型的構造 テ，之二依テ，從來，諸家，實驗方法二免ガレ難キ，其操作ニ件フ周圍組織， 變化カ，胃二與フル障礙 除去シ得タルガ故二, 潰場ノ發生部位及形態、一定 シ, 且, 胃ノ他部二, 病的變化》惹起スルコト, 極メテ輕微ナルモノニシテ, 胃潰瘍ノ本態 7 實驗的二，觀察フルニ當リテハ，余ノ方法ハ，最モ確實ナルモ ノト信ズ.

（2）胃潰歾ノ形態

余ノ實驗方法ニョリテ發生スル潰境入，其形成ノ初期二於テ，先ヅ，圆形， 
荐クハ, 楕圓形ナル邊緣部限界ヨ示シ, 其進行スルニアタリテ, 邊緣稍不規則 トナルモノアルモ，淮行停止シ，或ハ，治瘜機轉ヨ示スニ至レバ，總テ邊緣，

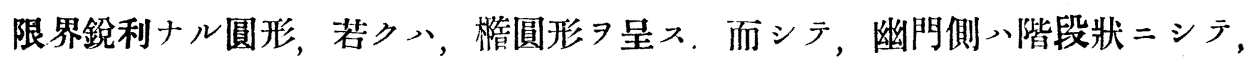

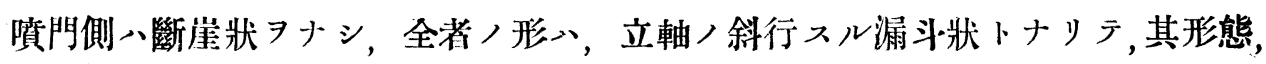

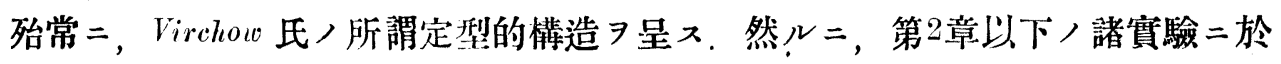
テ八, 其手術的操作ガ周圍組織, 變化

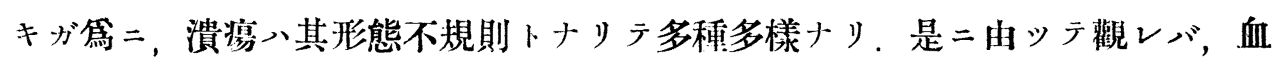
行障礙ノミアリラ他二胃ノ複雃ナル器珹的障礁 八，常二，定型的構造 $尹$ 呈スルEノト思惟ス.

\section{（）胃潰瘍，發生狀態。}

潰晹形成, 初期二當りテ入，粘膜下組織浡腫狀二膨隆シ，粘膜二於テ入，先 ッ゙，上皮層，胃小窩部壤死脫落シ，次二，胃腺部脫落スルモ，粘膜筋層八，抵 抗力强ク, 粘膜下組織ガ高度, 浮腫乃至壤死状態二陷りタル後, 初メテ離斷シ,

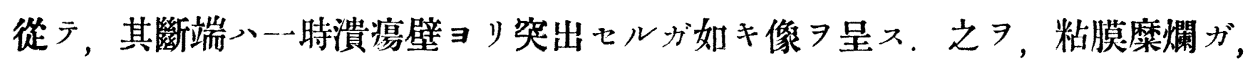
其孌化單二上皮層二限局スルニ比スレバ, 兩者, 其發生ノ狀態二著シキ差違ア

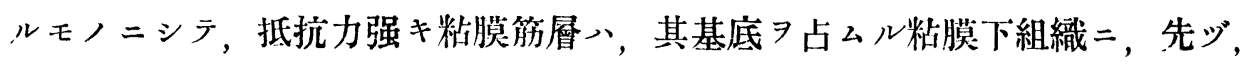
浮腫乃至壞死症狀，現レザル限リ容易二壤死離斷スルモノ二非ズ，且，本編諸 章, 實驗二徵スル二, 粘膜糜爛》, 極メラ早期二治癒シ消失ス. 余入, 從來, 粘膜糜爛カ胃潰湯二移行スト云フ一般諸家, 說ニ八, 賛同シ難キノミナラズ, 此雨者入，其發生機轉二於テ，明二區別セラルぶキモノナリ．

（4）胃潰演，治癒狀態。

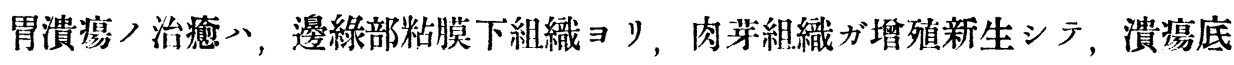
ヨ修理シ, 該肉芽組織八, 其基底部 $コ$, 次第二, 洀泿組織二變ズルト共二, 其表面八，增殖新生スル粘膜上皮層ニョリテ，被覆セラル、モノナリ．從ッラ， 潰演八治瘾機轉未ダ著シク進行セザルモノ二於テハ，表層二，滲出セル小圆形 細胞及白血球卜壞死物質卜ノ混合セル帶狀ノ薄愿アリテ，其基底部八，肉芽層 及洀泿層ニョリラ占メラル，而シテ，一般二，人類胃潰演，特二，慢性胃潰場 ト稱セレル、モノ、所見ハ，斯ル狀態习呈スルモノナリ， 


\section{（5）胃潰瘍，原因。}

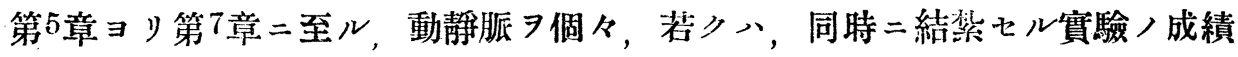
卜，幽門輪ヨリ左胃網動静脈二至ル間 $/$ 血管ノ結紫，切斷，或八，周圍組織卜

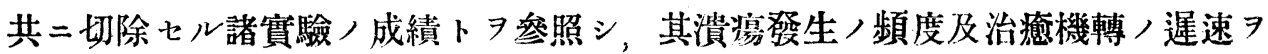
比較スルニ, 次ノ如キ結果 $习$ 得タリ.

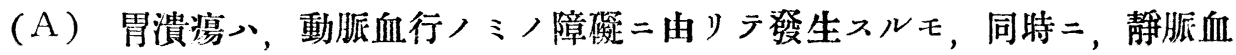

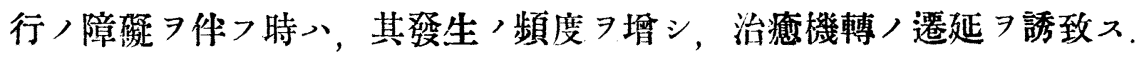

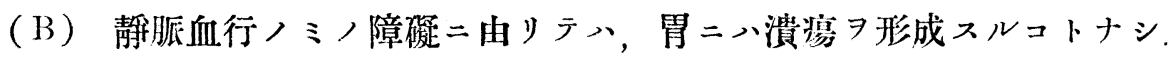

（i）好 發 部 位。

幽門輪ヨリ左胃網動静脈二至ル，總デ，血行 十二指腸動脈ノミノ血行 $\ni$ ，遮斷セル㙫合卜同樣二，常二，幽門部大彎二潰湯 ヨ發生スルョ以テスレバ，胃大彎二於テ，血管吻合ノ最モ嚾少ニシテ，潰場，

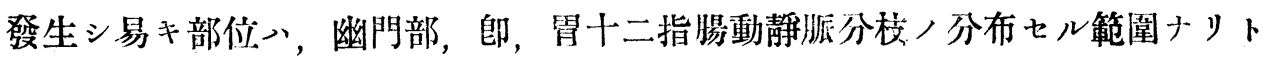
云フべシ.

\section{（７）副血行新生ノ潰場二及ボス影響}

第 8 章ノ實驗成績ニ示スガ如ク，腸管ノ瘉著二件フ，胃壁副血行ノ新生ハ,

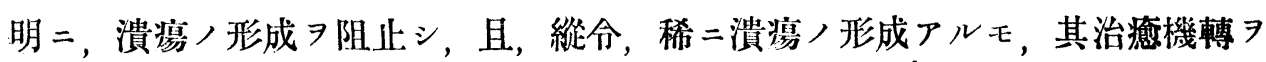

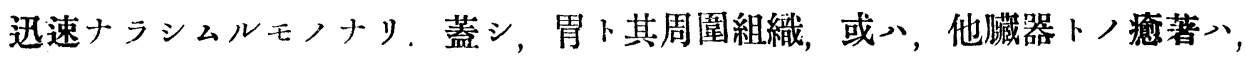

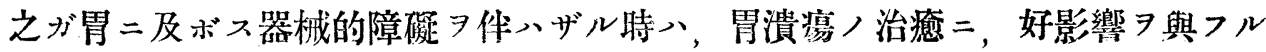
モノナリ.

本編概要八，之 7 昭和 3 年 4 月，第 18 回，日本病理學會總會二於示發表シ， 其抄錄, Virchows Archir für Path. Anatomie 11. Physiologie 269 Bd., :3.Heft. 二揭載セリ。

閵筆二臨ミ，京大藤浪教授ノ御䈍篤ナル御指導卜御校閱卜ヨ深謝シ，併セテ 當院病理科醫長本田蘭博土ノ終始御熱誠ナル御援助 7 感謝ス。

\section{Literaturverzeichnis.}

1) Aschoff, Ueber die mechan. Momente in d. Pathogenese d. rund. Magengeschwärs u. über seine Beziehung z. Krelss. Deut. med. Wochenschr., Nr. 11, 1912. 
Ascanazy, Aetiologie u. Pathogenese d. rund. Magengeschwürs. Revue med. de la suisse romande, Nr. 8, 1920. Ref. in Zentralbl. f. Chir., Nr. 3, 1921.

3) Busse, Ueber postoperative Magen- u. Darmblutnngen. Arch. f. klin. Chir., Bd. 76, 1905.

Cruveilhier, Traité dánatomie patologique géneralé. tome 4, Paris 1862.

Eiselberg, Ueber Magen- u. Duodenalblutungen nach Operationen. Arch. f. klin. Chir., Bd. 59, 1899.

6) Engelhard u. Neck, Veränderungen an Leber u. Magen nach Netz- abijindungen. Deut. Zeitschr. f. Chir., Bcl. 58, 1901.

7) Friedrich, Experiment. Studien über d. Folgen von Netzalterationen für Leber (Infarkt) u. Magen (Geschwürsbildung). Verhandl. d. deut. gesellsch. f. Chir S. 50, 1900.

8) Gundermann, Ueber experiment. Erzeugung v. Magen- u- Darmgesch-wiren. Arch. f. klin. Chir., Bd. 101, 1913.

9) Hoffmann, Studien über d. Folgen v. Netzabbindungen u. Alterationen auf Leber u. Magen. Ing. Diss. Leipzig (Cit. nach Möller).

Hoffmann u. Nather, Zur Anatomie d. Magenarterien. Ein Beitrag z. Aetiologie d. chr. Magengeschwïres u. seiner chir. Behandelung. Arch. f. klin. Chir., Bd. 115. 1921.

11) Kawamura, Zur Frage d. Verdauung lehenden Geweises im Magen, zugleich ein Beitrag zur Pathogenese d. rund. Magengeschwïres. Mitteil. a. d. Grenzgeb. d. Med. u. Chir., Bd. 26, 1913. 12) Derselbe, Ueber d. experiment. Erzeugung v. Magengeschwüren durch Nervenläsionen. Deut. Zeitschr. f. Chir., Bd. 109, 1911.

13) Katzenstein, Der Süitz d. Magens gegen d. Selbstverdauung nebst einem Vorschlag zur Behandlung d. Ulcus ventriculi. Berl. klin. Wochenschr., Nr. 39, 1908.

14) Mandl, Die Hernia d. I.inen allsa u. ihre Beziehung zu d. ulcerösen Processen d. Magens u. Duodenum. Arch. f. klin, Chir., Bd. 115, 1921. 15) Miiller, Beitrag zur Histologie u. Pathologie d. Ulcus pepticum ausserhalb u. innerhalb d. Magens. Bruns' Beitr. z. klin. Chir., Bd. 123, 1921. 16) Payr. Experimente über Magenveränderungen als Folge von Trombose u. Embolie im Pfortadergebiete. Arch. f. klin. Chir. Bd. 84, 1907,

17) Stahmer, Zur Frage d. Entstehung v. Magengeschwïren u. Leber-infarkten nach Netzresektion. Deut. Zeitschr. f. Chir., Bd. 61, 1901.

18) Virchow, Handbuch d. spec. Pathologie u. Therapie. Bd. 6, 1855.

19）毒山微藏，胃潰揚二就 $テ$ 。日本外科學會雜誌，第24问， 第10號，大正12仵7月。 20）磯部喜右湋鬥，胃潰煌 /原因二關スル實驗的補遺，日本

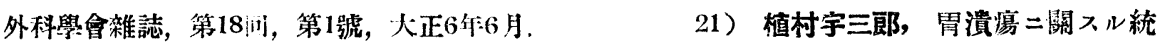
計的臨床的及寒驗的研究，日本外科學拿䆶誌，第19可，第6號，大正8年2月．同，第19可，第

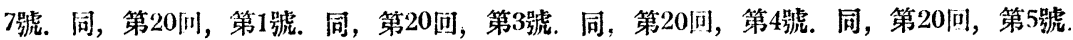

22）宇野鬼一郎，胃潰演卜膵淮卜八關係二就示，日新醫學，第12年，第 4 號，大正 12 年 4 月.

23）大野章三，胃潰湯發生論，日新醫學，第8年，第3 號，大正 8 年 3 月.

24）熊野

彻堂進，胃二到ル神經卜胃潰煌治煗卜ノ關係，日本外科學會雜誌，第25回，第6號，大正13年 9月. 同, 25问，第7號.

25）久米久之，十二指腸圓形潰惕／實驗的研究二就 $テ ， 日$ 本病理學會雜誌，第17年，炤和3年1月. 26）啳藤七郎，胃腸二於ル所謂消化性潰瘍， 日本外科學會雜誌，第22回，第5號，大正10年8月. 27）近森正基，慢性胃溃瘍二關 スル實驗的砸究，日本外科學會雜誌，第23问，第10號，大正12年1月．同，第23问，第11號。

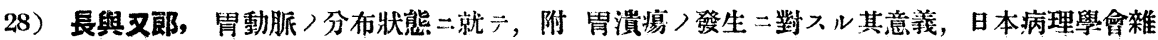


誌, 第4哭, 大正4年1月.

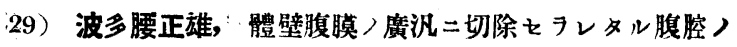
運命二就 $\vec{\sim}$, 日本外科兽會雜誌, 第19回, 第7號, 大正 8 年 3 月.

30) 本田有也，急性 及慢性胃溃境＝關スル胃血管變化／意義，京都㗨學會雜誌，第21替，第7號，大正13年7月.

31）本田郁也，余が圆形胃潰韵成因觀／補遺，日新醫學，第 16 年，第 10 號，昭和 2 年 6 月。同， 第16年, 第11號。

\section{附圖 說 明}

第 1 圆實驗家鬼第 2 號 術媛 1 日。第 2 圖 實驗家鬼第 5 號 術後 3 日。第 3 圖 實驗 家鬼第 7 號 術後 4 日。第 4 圆實驗家鬼第 8 號術後 5 日. 第 5 圆實驗家兔第 10 號 術後 7 日. 第 6 圖 實驗家兔第 13 號 術後 8 日. 第 7 圆 實驗家兔第 16 號 術後 10 日.

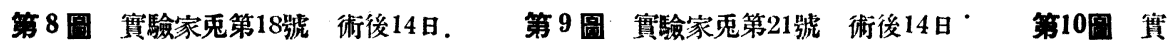
驗家鬼第23號 術後21日。第11圖 實驗家鬼第30淲 術後36日。第12圆 實驗家兔31號

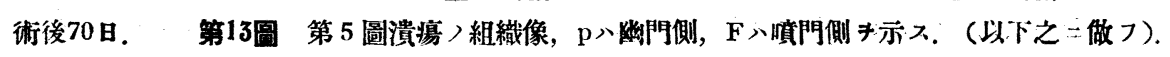

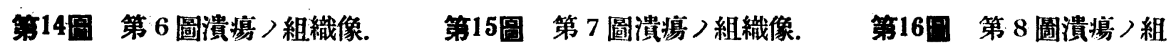

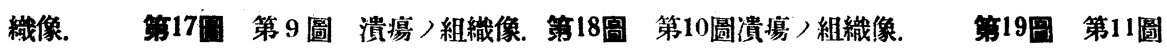

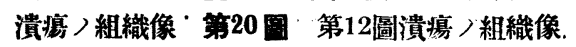


小俣論文附圖 (I)

(1)

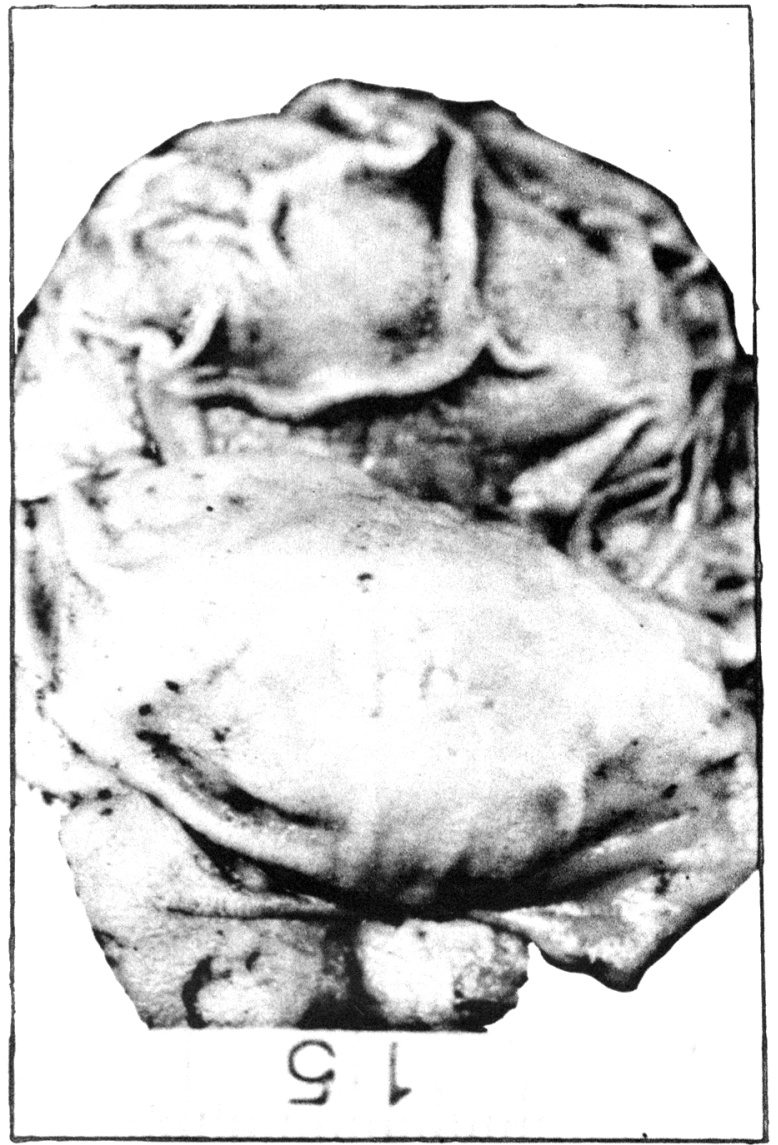

(3)

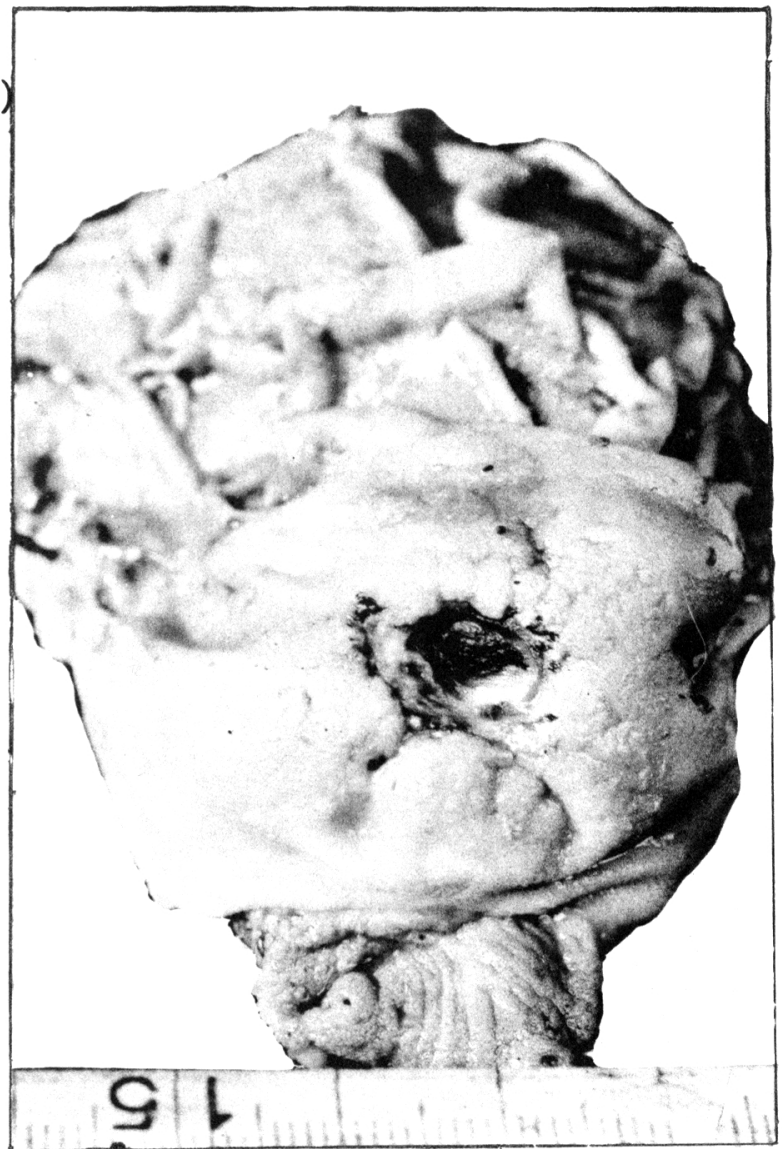

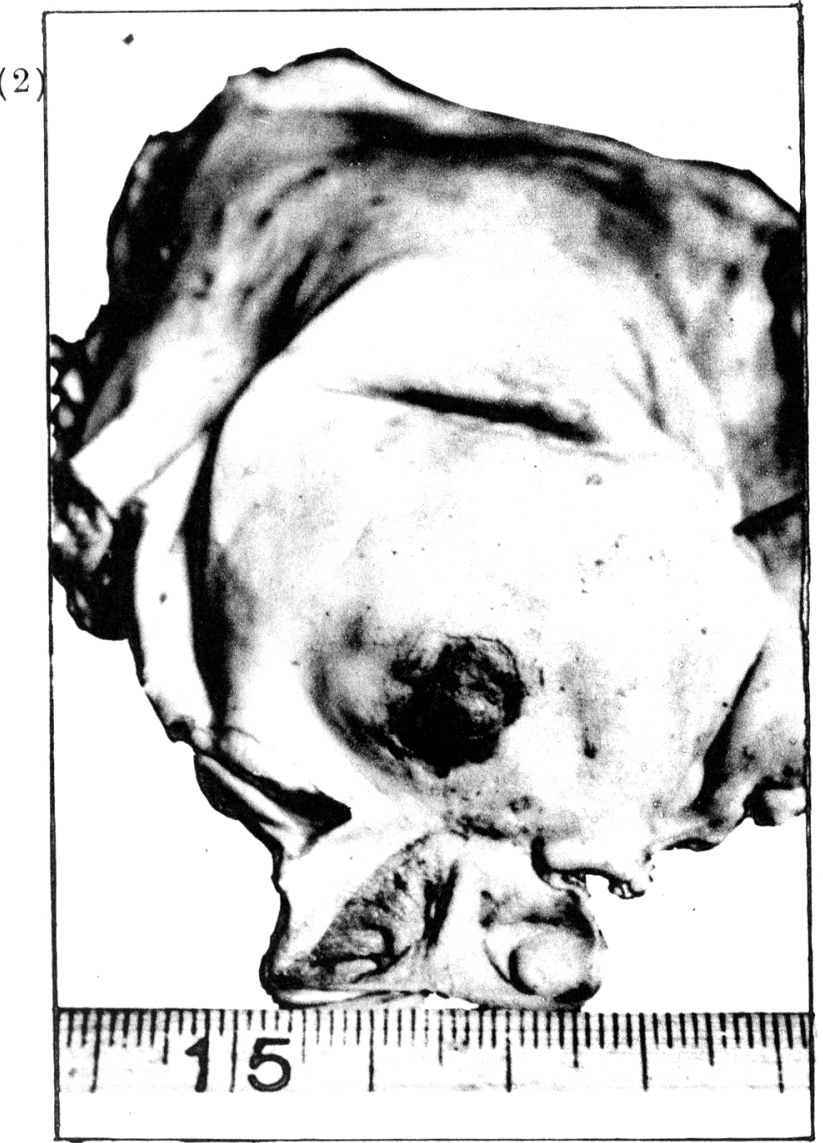

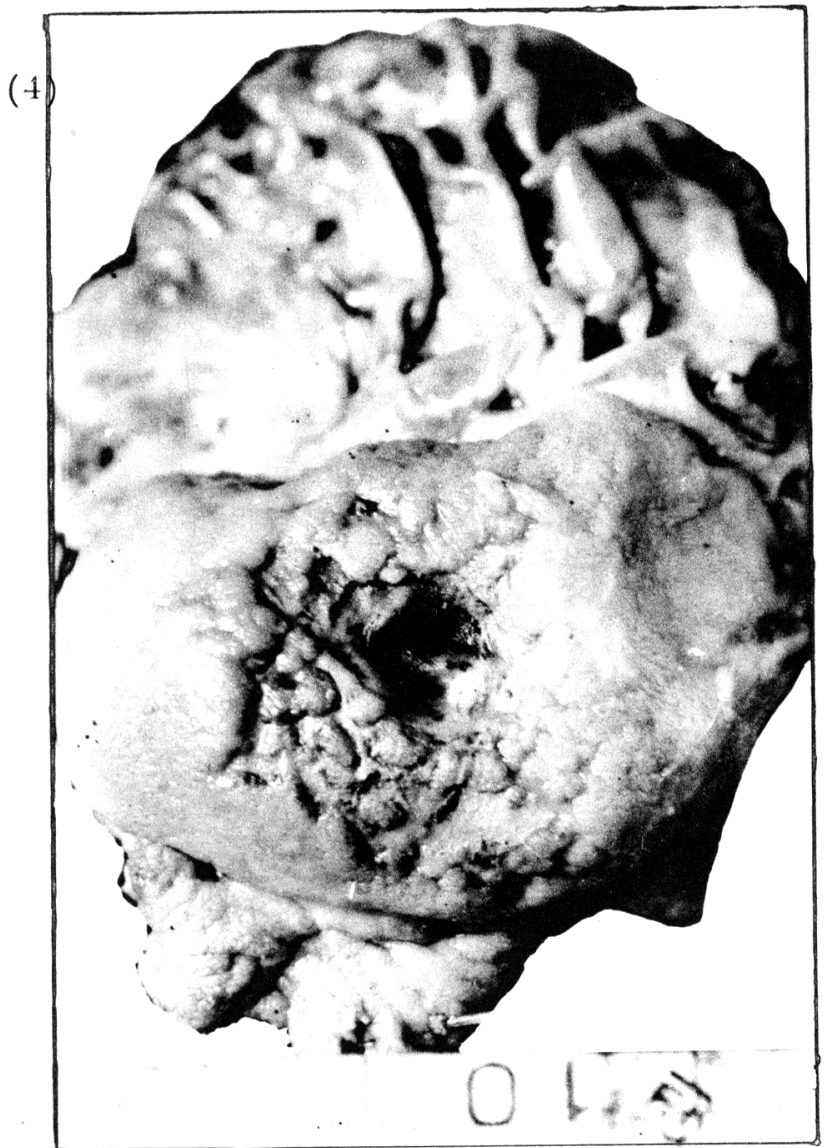


小俣論交附圖 (II)

(5)

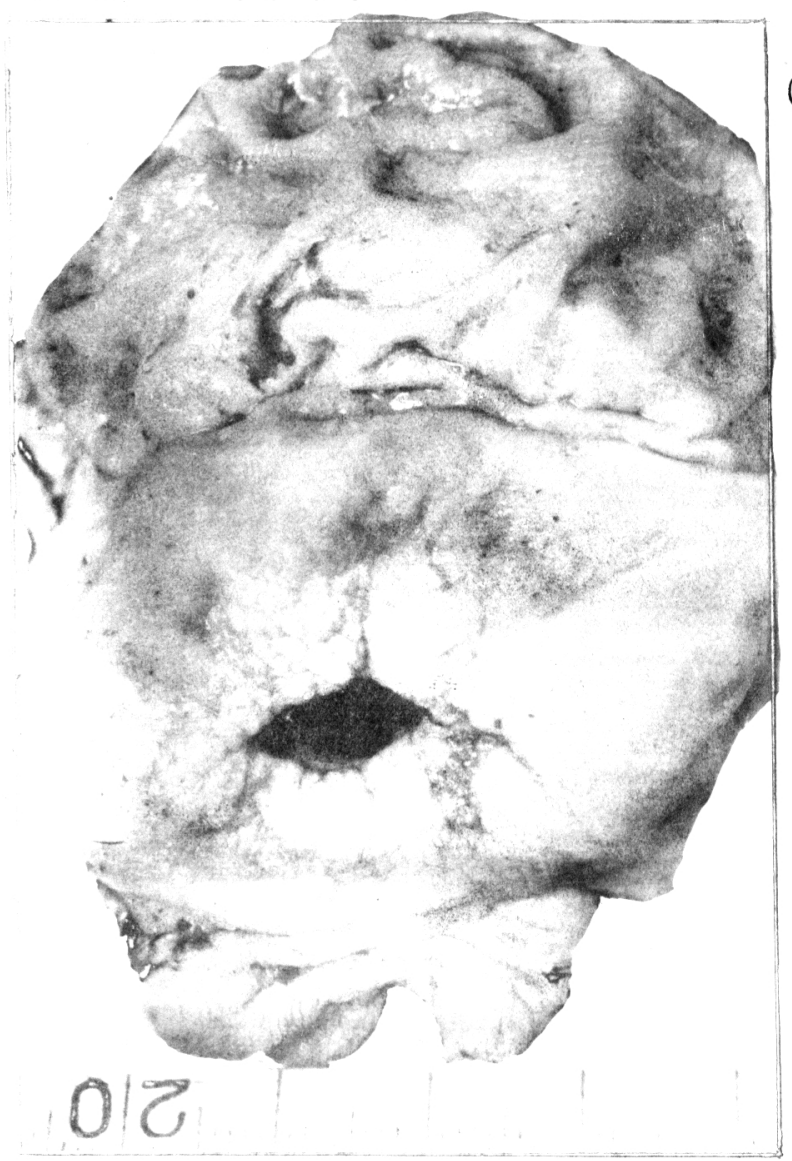

(7)

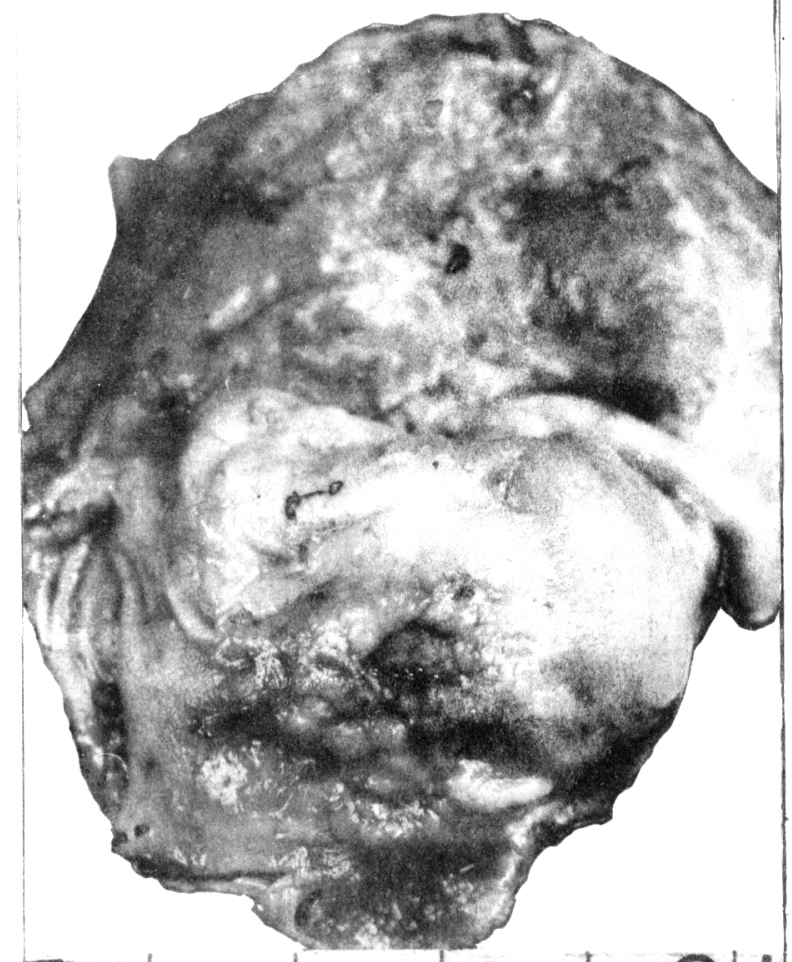

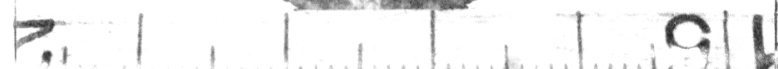

(6)

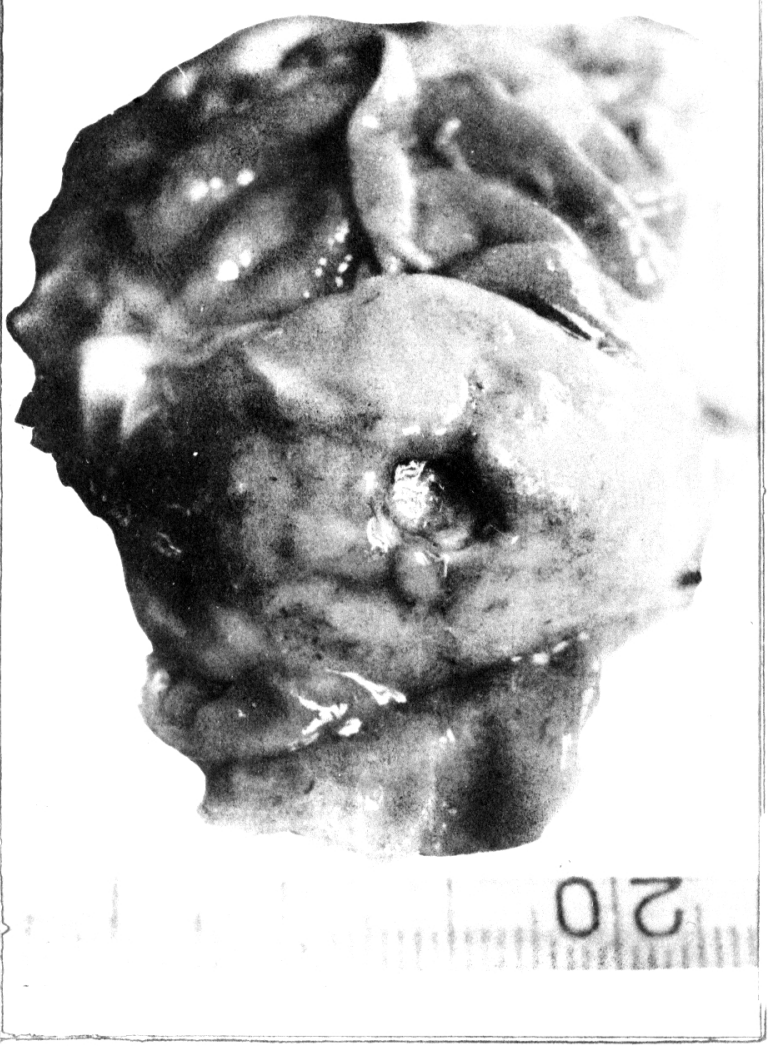

(8)

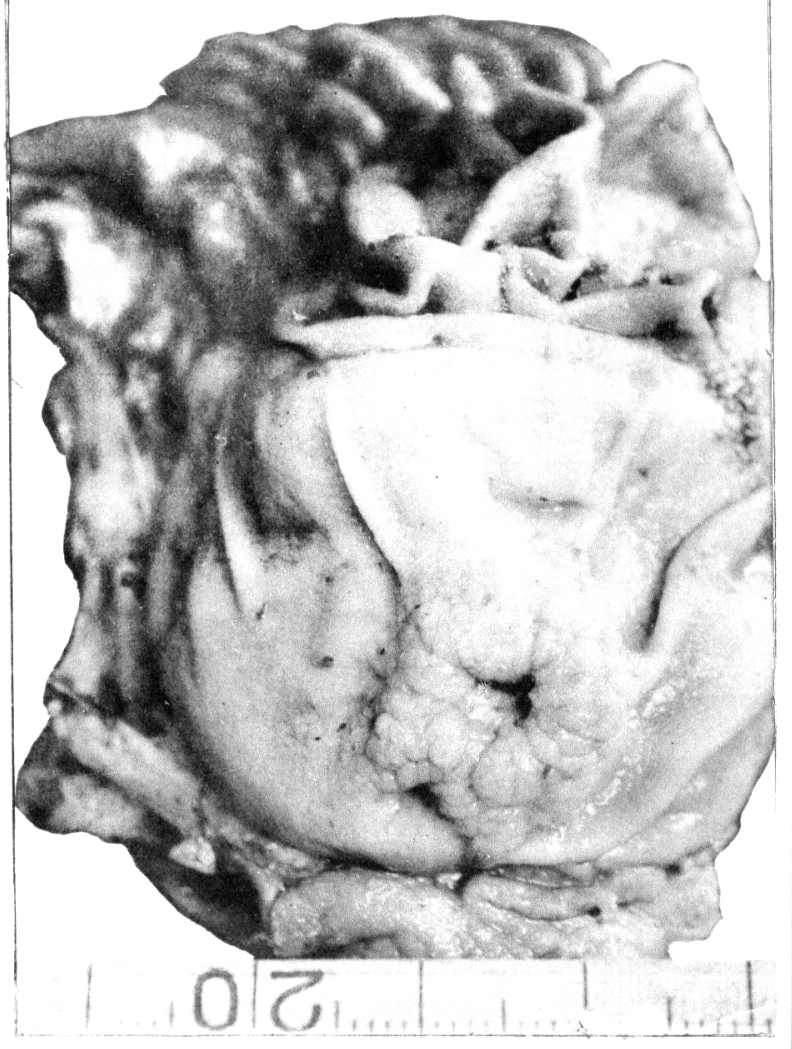


小俣論交附圖(III)

(9)

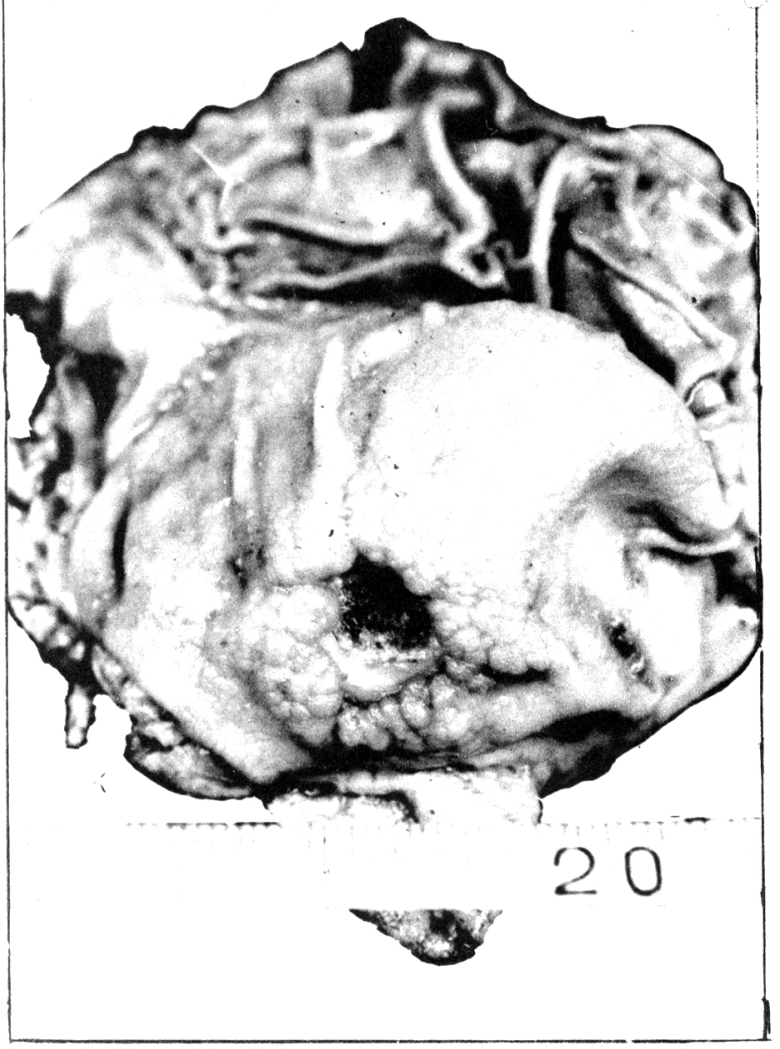

(11)

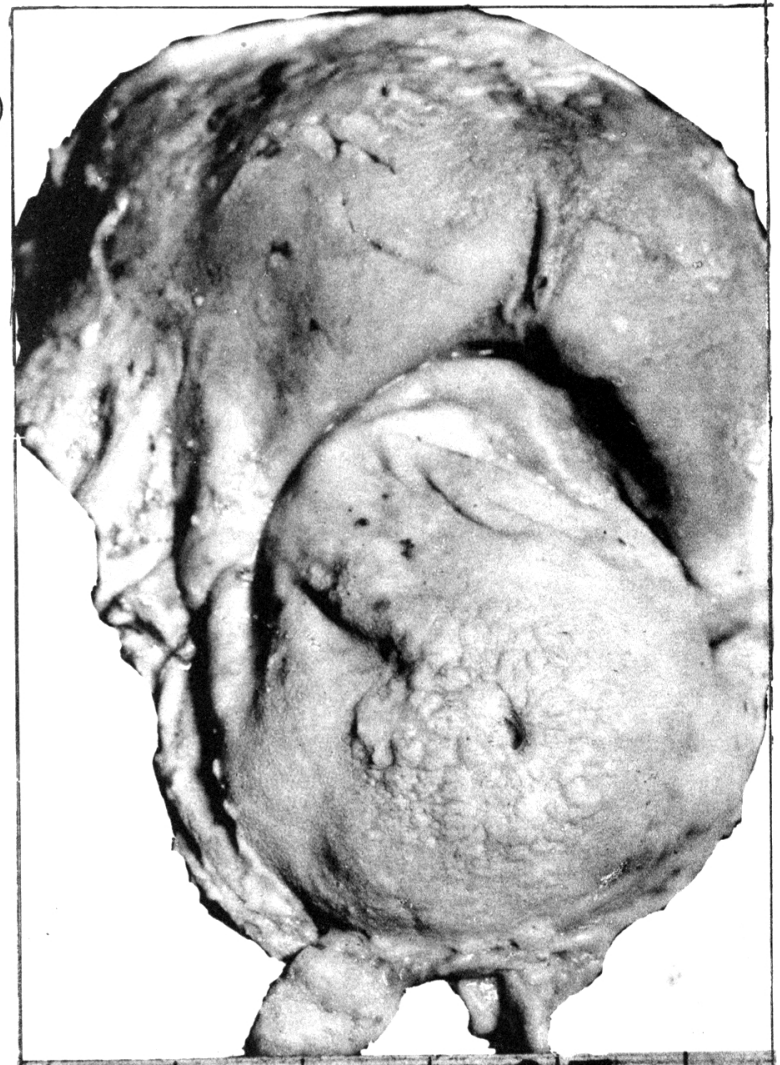

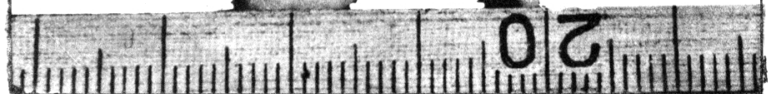

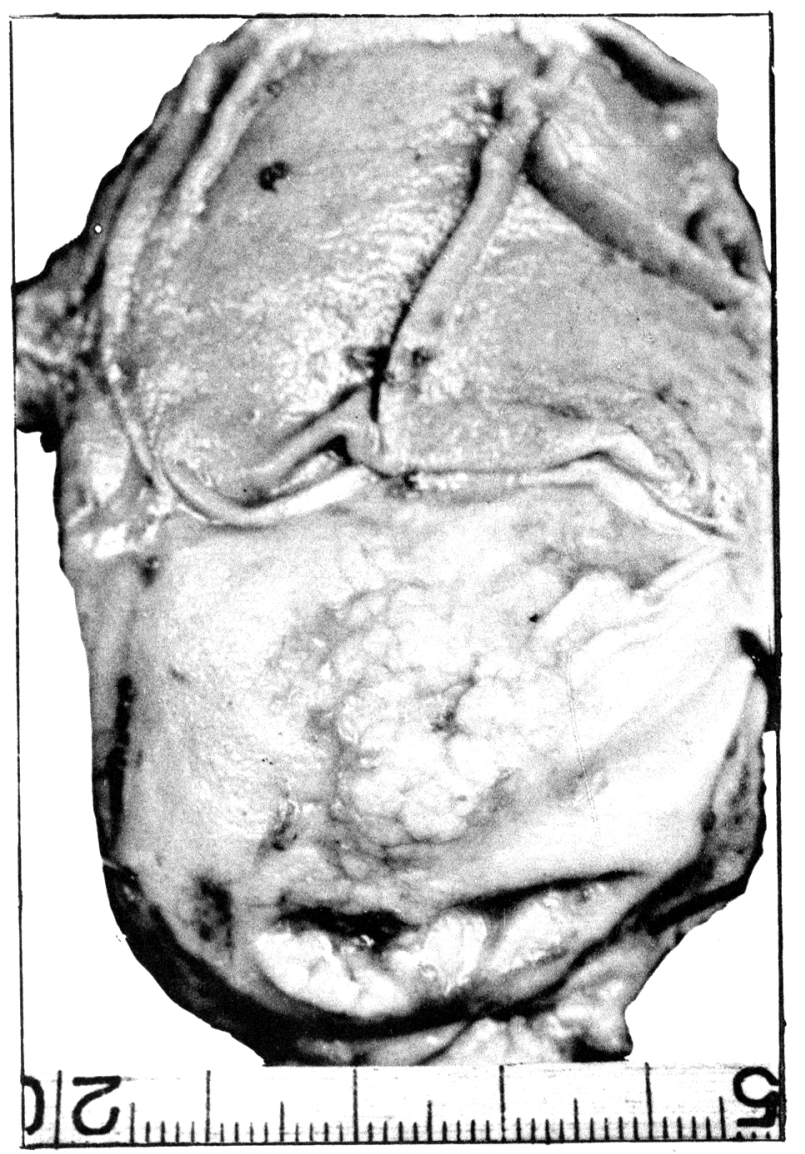

(12)

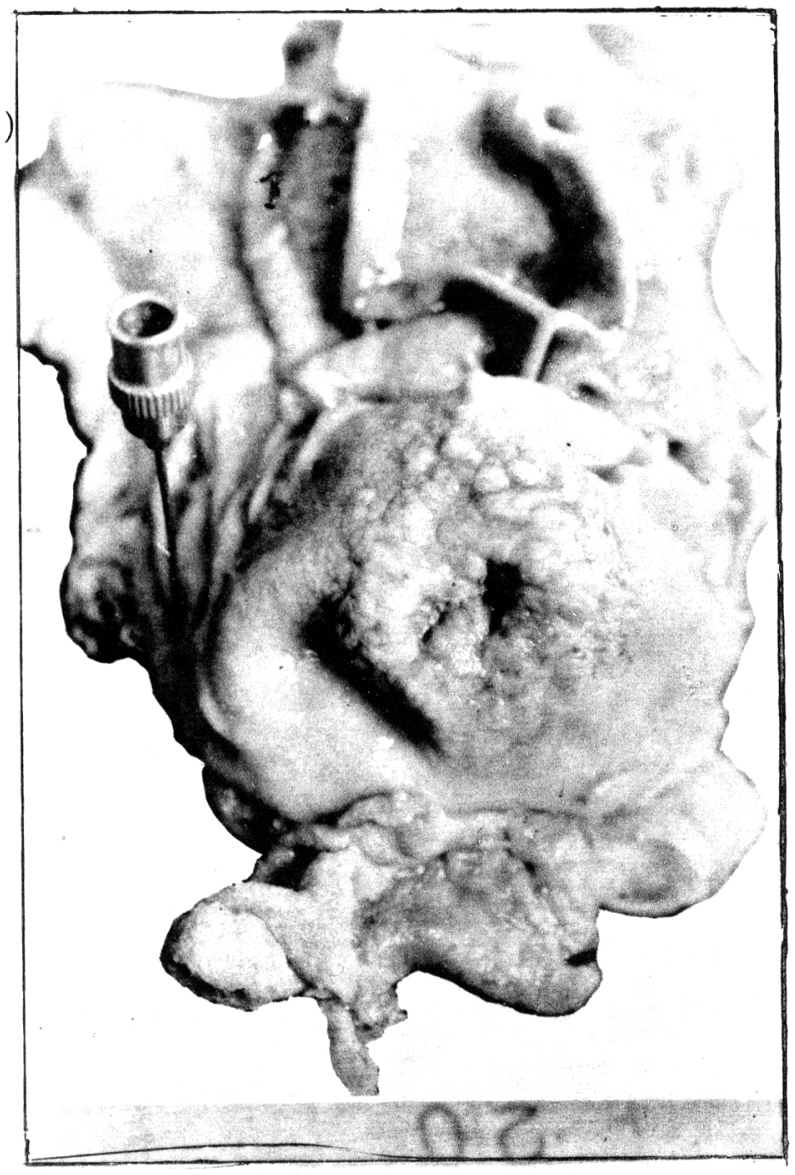


小俣論交附圖(而)

(13)

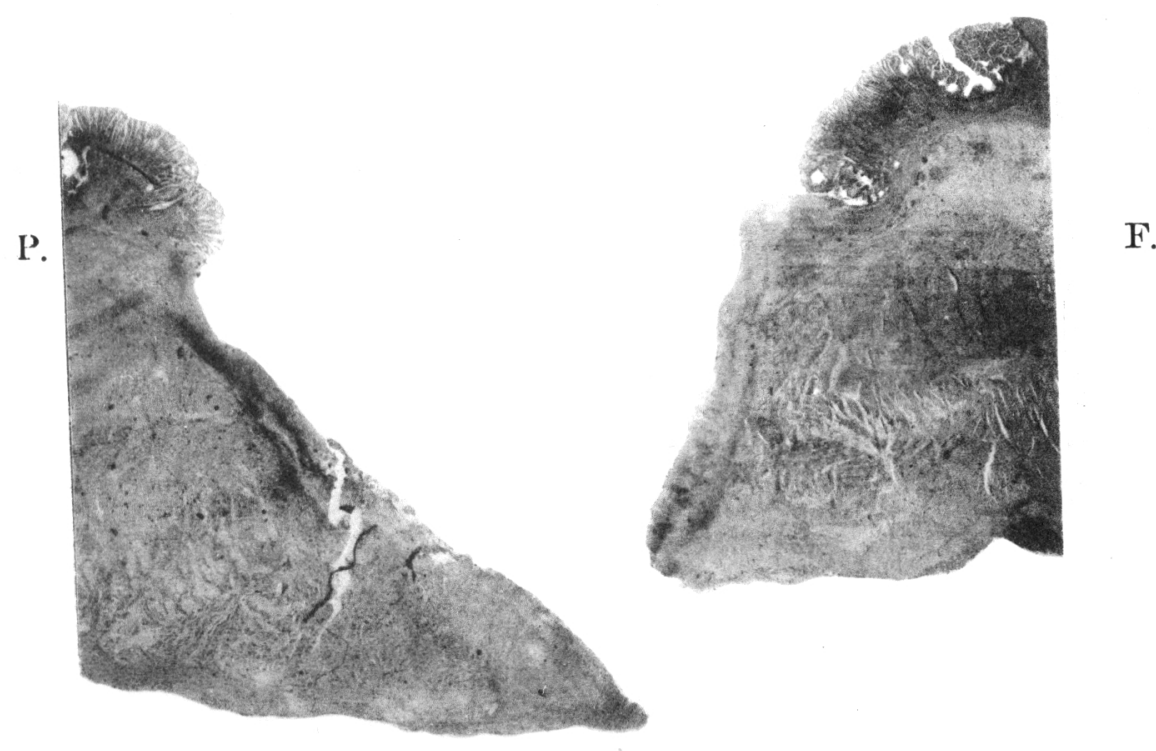

(14)

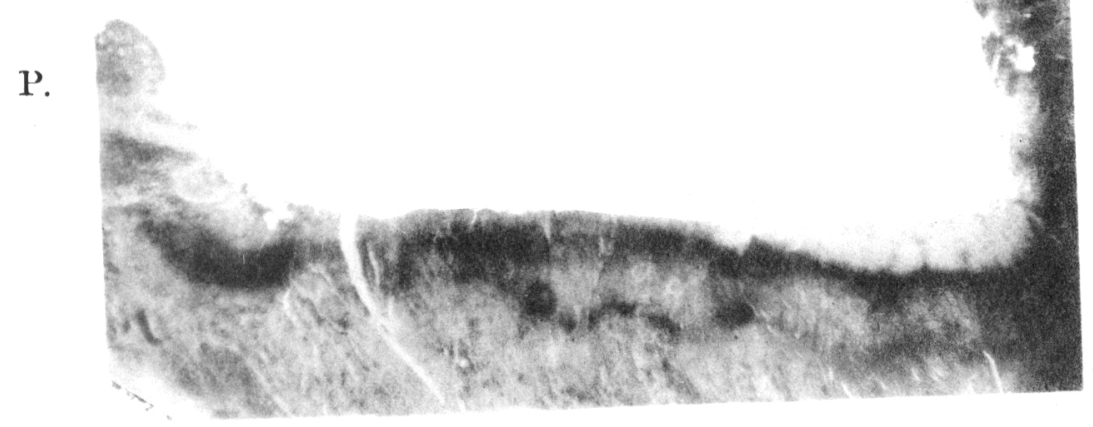

F. 

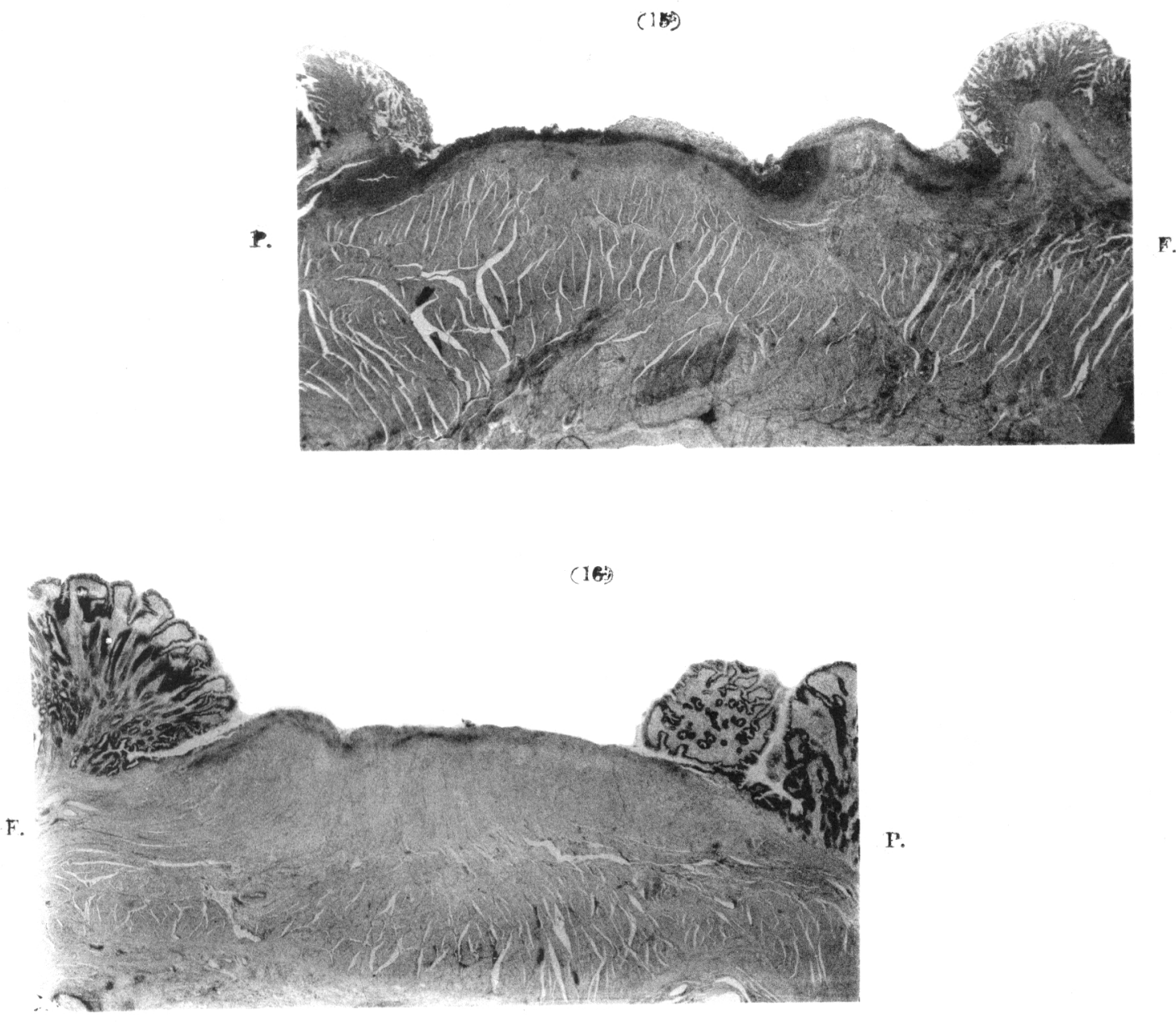

P.

(17)

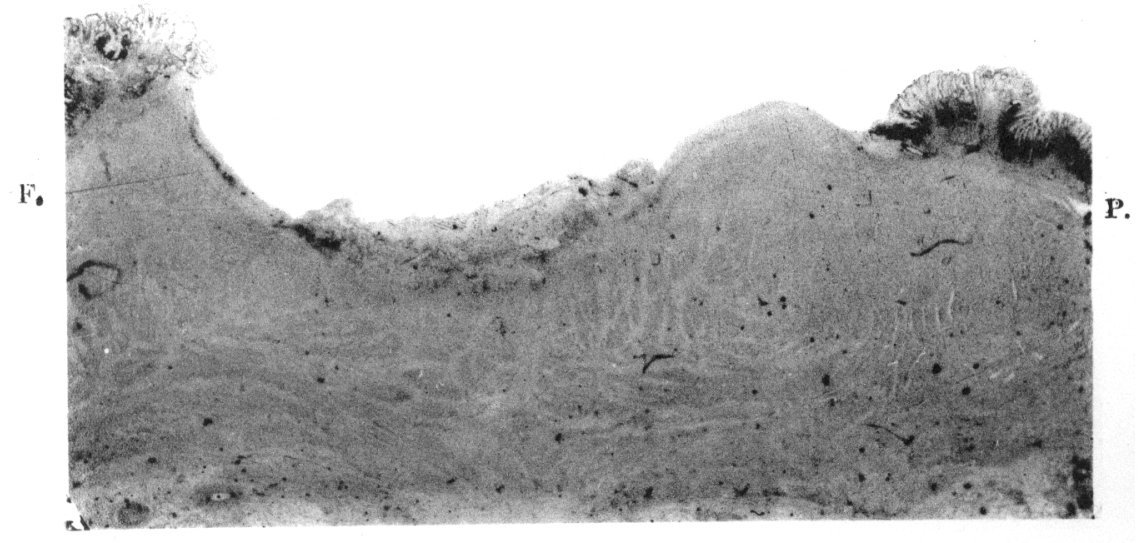


小俣論交附圖 (VI)

F.

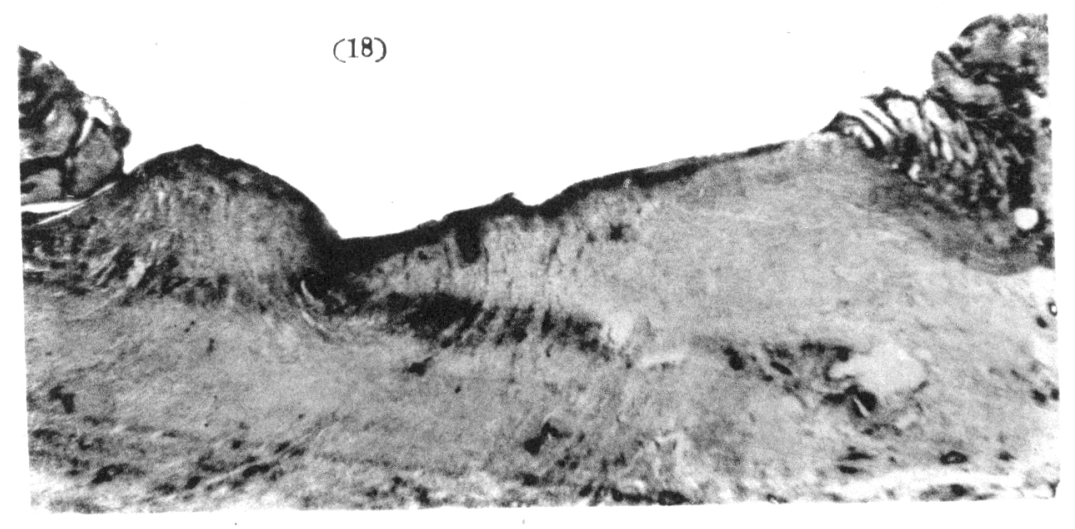

P.

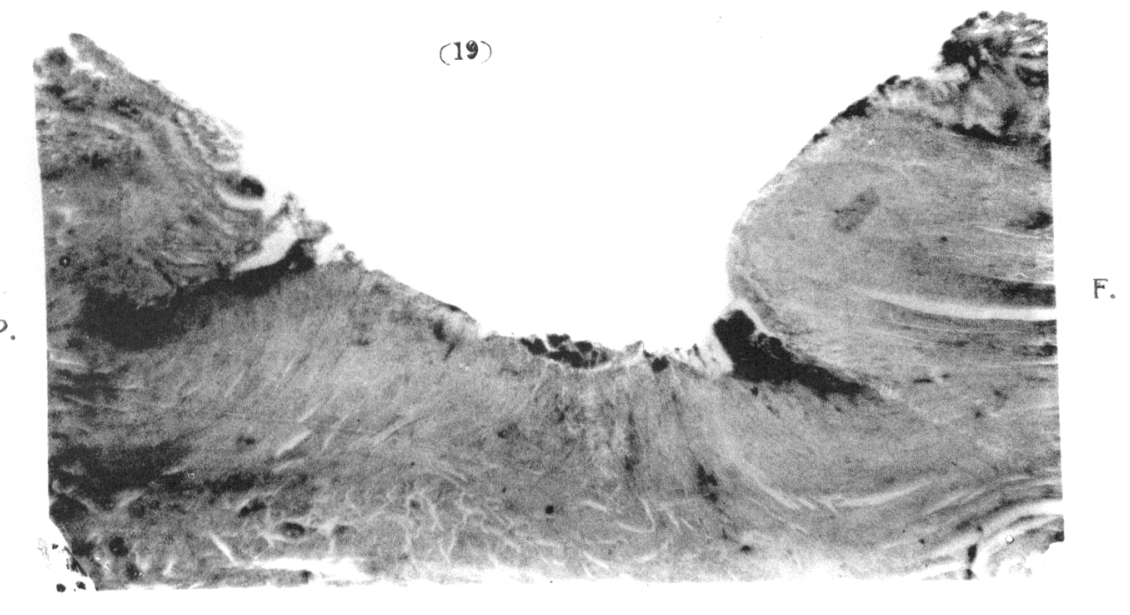

P.

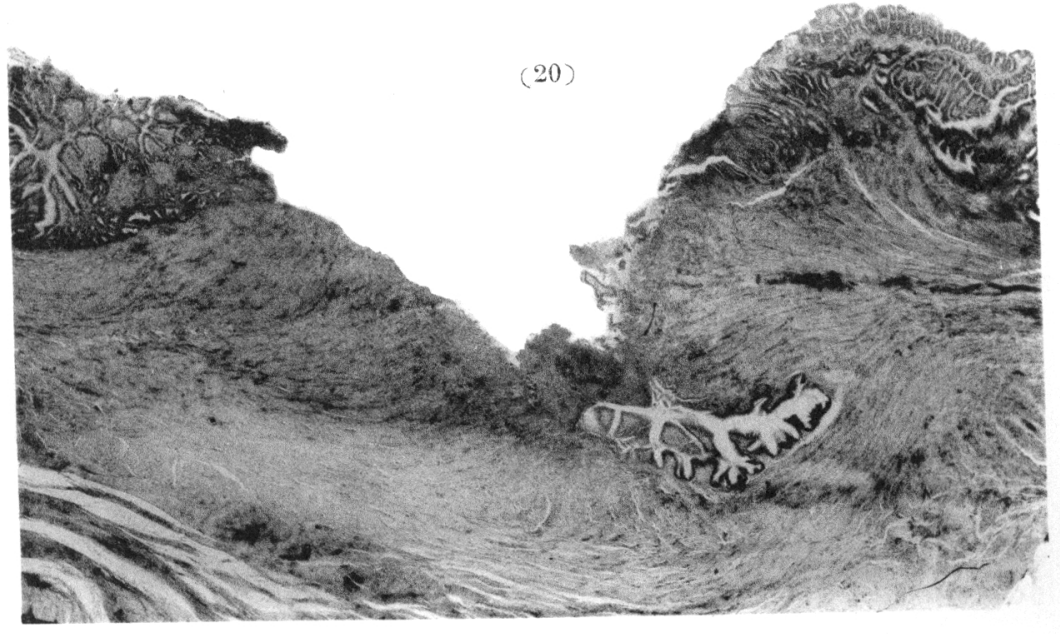

